Prepared in cooperation with Sonoma County Water Agency and Santa Cruz County Department of Environmental Health Services

\title{
Simulation of Climate Change in San Francisco Bay Basins, California: Case Studies in the Russian River Valley and Santa Cruz Mountains
}

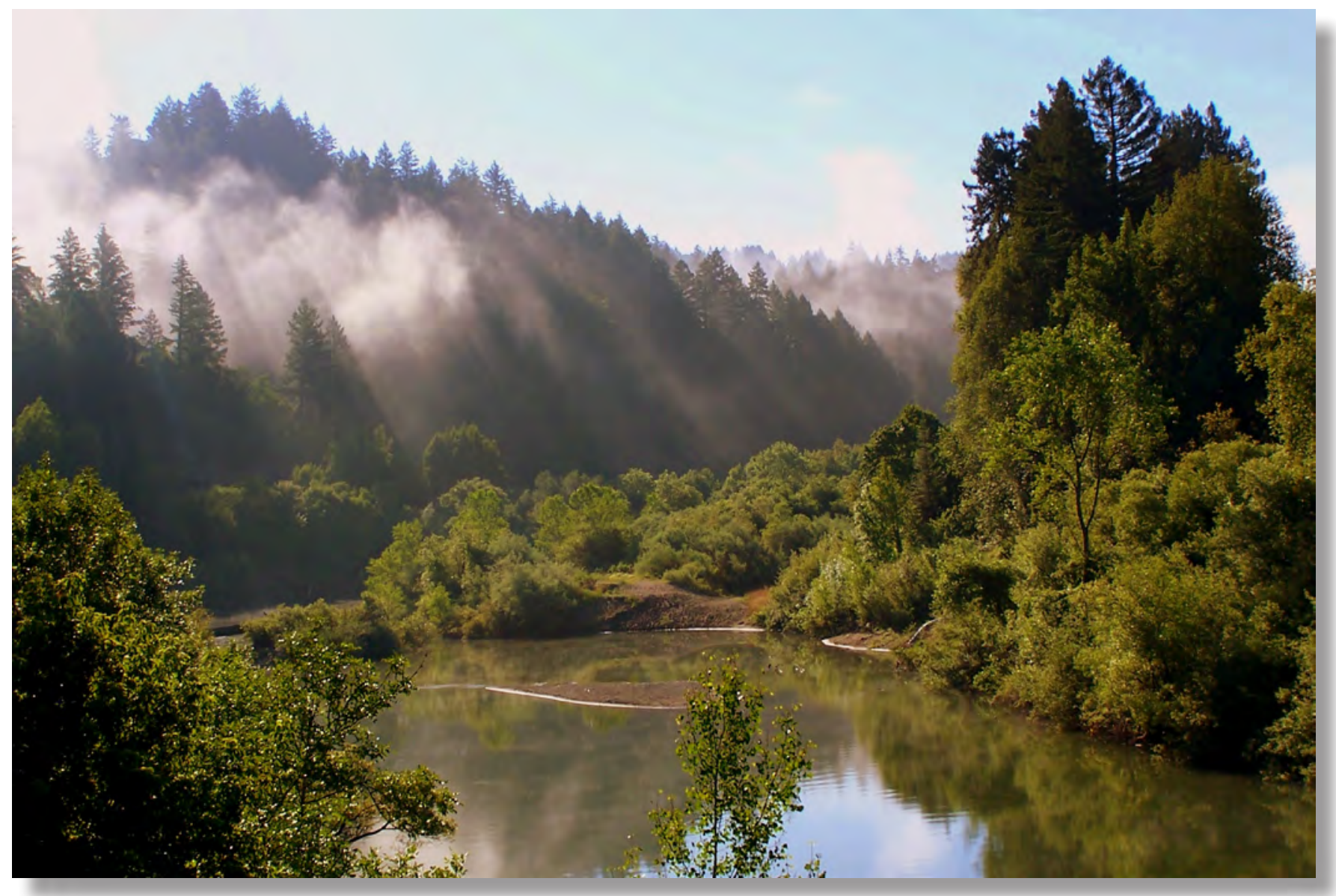

Scientific Investigations Report 2012-5132 
Photograph: Russian River, Sonoma County Water Agency, 2012 


\section{Simulation of Climate Change in San Francisco Bay Basins, California: Case Studies in the Russian River Valley and Santa Cruz Mountains}

By Lorraine E. Flint and Alan L. Flint

Prepared in cooperation with Sonoma County Water Agency and

Santa Cruz County Department of Environmental Health Services

Scientific Investigations Report 2012-5132 


\title{
U.S. Department of the Interior \\ KEN SALAZAR, Secretary \\ U.S. Geological Survey \\ Marcia K. McNutt, Director
}

\author{
U.S. Geological Survey, Reston, Virginia: 2012
}

For more information on the USGS - the Federal source for science about the Earth, its natural and living resources, natural hazards, and the environment, visit http://www.usgs.gov or call 1-888-ASK-USGS.

For an overview of USGS information products, including maps, imagery, and publications, visit $h t t p: / / w w w . u s g s$. gov/pubprod

To order this and other USGS information products, visit http://store.usgs.gov

Any use of trade, product, or firm names is for descriptive purposes only and does not imply endorsement by the U.S. Government.

Although this report is in the public domain, permission must be secured from the individual copyright owners to reproduce any copyrighted materials contained within this report.

Suggested citation:

Flint, L.E., and Flint, A.L., 2012, Simulation of climate change in San Francisco Bay Basins, California: Case studies in the Russian River Valley and Santa Cruz Mountains: U.S. Geological Survey Scientific Investigations Report 2012-5132, 55 p. 


\section{Acknowledgments}

This study was supported by the Sonoma County Water Agency and the Santa Cruz County Department of Environmental Health Services (DEHS). Partial funding for the Santa Cruz County DEHS was provided through an agreement with the State Water Resources Control Board.

The contents of this document do not necessarily reflect the views and policies of State Water Resources Control Board, nor does mention of trade names or commercial products constitute endorsement or recommendations for use.

Much appreciation is extended to USGS reviewers Scott Wright and Linda Woolfenden who provided many thoughtful comments and improvements to the manuscript. 
This page intentionally left blank. 


\section{Contents}

Abstract

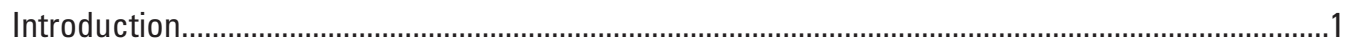

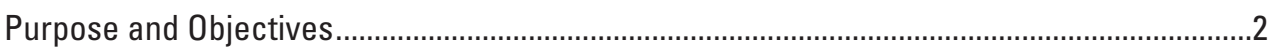

Description of the Study Area .......................................................................................

Characteristics of Bay Area Climate ....................................................................................

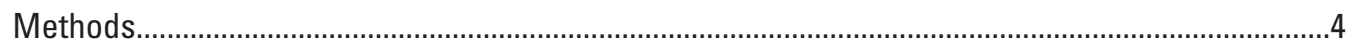

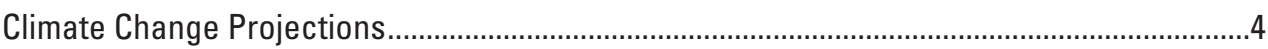

Basin Characterization Model..........................................................................................

Downscaling Climate Data for Model Application ....................................................................

Calibration to Measured Streamflow …………………......................................................11

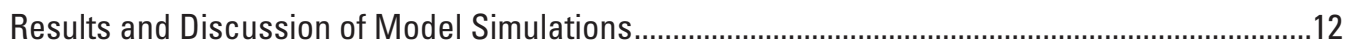

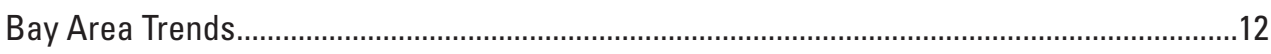

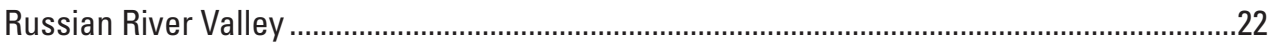

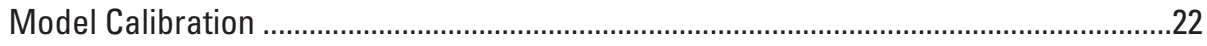

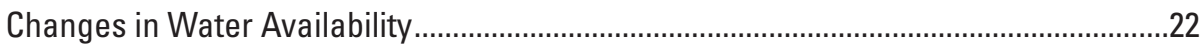

Landscape Effects .................................................................................................29

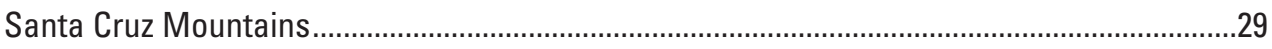

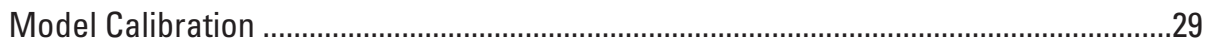

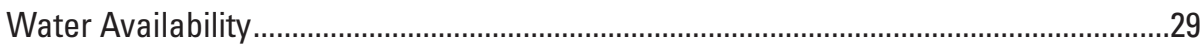

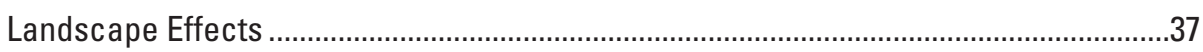

Hydrologic Comparison of Russian River Valley and Santa Cruz Mountains ...........................38

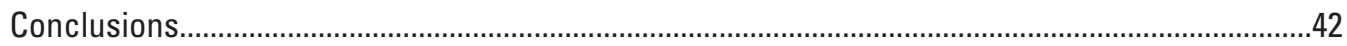

Implications for Resource Managers.............................................................................

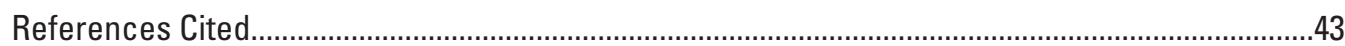

Appendix 1 Mean 30-Year Values for Climate and Water-Balance Components for Current and Four Future Projections for Major Water Supply Basins in the Russian River Valley, California ...

Appendix 2 Cumulative Frequency of Basin Discharge for All Basins in the Santa Cruz Mountains, California .......................................................................................................

Appendix 3 Mean 30-Year Values for Climate and Water-Balance Components for Current and Four Future Projections for Major Water Supply Basins in the Santa Cruz Mountains, California 


\section{Figures}

1. Map showing San Francisco Bay Area, California, basins .

2. Maps showing spatially distributed average annual precipitation, maximum air temperature, and minimum air temperature for San Francisco Bay area, California, basins $(A)$ during 1971-2000, and $(B)$ change in annual averages between 1971 and 2000 .

3. Measured global carbon dioxide (CO2) emissions compared to Intergovernmental Panel on Climate Change (IPCC) emissions scenarios.

4. Map showing surface geology and associated estimates of surficial bedrock permeability (K) for basins in the San Francisco Bay Area, California.

5. Map showing otal soil available water content (calculated at field capacity minus water content at wilting point multiplied by soil depth) for basins for basins in the San Francisco Bay Area, California.

6. Maps showing downscaled maps of maximum air temperature for June 2035 for basins in the San Francisco Bay Area, California, at spatial resolutions of $(A)$ 12-kilometers (km), (B) 4-km, and (C) 270-meters.

7. Graphs showing historical climate and four projections shown by decadal (10-year) average precipitation and maximum air temperature for basins in the San Francisco Bay Area, California.....

8. Graphs showing historic and projected precipitation and maximum air temperature depicted with 30-year histograms for 1911-2100 under the A2 scenario for the $(A)$ entire San Francisco Bay Area, $(B)$ Russian River Valley, and (C) Santa Cruz Mountains.

9. Maps showing the spatial distribution of runoff and recharge for basins in the San Francisco Bay Area, California, (A) during 1971-2000 and (B) its change between 1970-2000 and 2070-2100 for GFDL-A2 and PCM-A2 projections.

10. Spatial distribution of climatic water deficit for basins in the San Francisco Bay Area, California, for $(A)$ the 1971-2000 average and $(B)$ its percent change between 1970-2000 and 2070-2100 projected by GFDL-A2 and PCM-A2.

11. Map showing areas of mapped redwood forest in the San Francisco Bay Area, California, basins $(A)$ currently and $(B)$ bioclimatic distribution of climatic water deficit in areas of redwood forest for current and future 30-year periods by using the GFDL-A2 projection.

12. Map showing location of calibration basins, streamflow gages, and model nodes used by the Sonoma County Water Agency in the Russian River Valley, California .......23

13. Map showing comparison of measured basin discharge to discharge simulated using the Basin Characterization Model (BCM) for streamgages at Feliz Creek and Maacama Creek near Kellogg in the Russian Basin, California, including goodness-of-fit analyses of Nash-Surcliffe Efficiency error (E) and coefficient of determination $\left(\mathrm{r}^{2}\right)$.

14. Graphs showing cumulative frequency of basin discharge for two subbasins in the Russian Basin, California, for historic (1971-2000) and projected (2071-2100) 30-year periods from GFDL-A2 and PCM-A2

15. Graphs showing historic measurements and two projected discharge estimates in 3-year running averages for two subbasins in the Russian Basin, California, $1920-2100$

16. Graphs showing historical measurements and two estimated future projections of precipitation, potential evapotranspiration, recharge, and runoff shown by mean 30-year monthly averages for the Russian River Valley, California. 
17. Maps showing range of suitable habitat for redwood forest based on climatic water deficit describing the bioclimatic distribution of $(A)$ a historical and $(B)$ a future period from the GFDL-A2 projection in the Russian River Valley, California..........30

18. Map showing average climatic water deficit of the current bioclimatic distribution for redwood forest in the Russian River Vally, California, showing the middle 80 percent of range and the upper and lower 10 percent tails.

19. Map showing average climatic water deficit projected for 2071-2100 for the current bioclimatic distribution of redwood forest in the Russian river Valley, California, showing the middle 80 percent of range and the upper and lower 10 percent tails

20. Map showing calibration basins and streamgages, and urbanized and cultivated areas in the Santa Cruz Mountains, California

21. Graphs showing examples of comparison of simulated to measured basin discharge for streamgages at Zayante Creek at Zayante and West Branch Soquel Creek near Soquel, California, from 1959 to 1972

22. Graphs showing Cumulative frequency of basin discharge for two subbasins in the Sant Cruz Mountains, California, for 1971-2000 and for 2071-2100 as projected by GFDL-A2 and PCM-A2.

23. Graph showing basin discharge at Soquel Creek at Soquel, California, shown by historic and two projected 3-year running averages for 1920-2100.

24. Map showing recharge areas and associated contributing areas overlying historical recharge (1971-2000) estimate from the BCM for the Santa Cruz Mountains, California.

25. Map showing change in recharge between 1970-2000 and 2071-2100 for GFDL-A2 and PCM-A2 projections for the Santa Cruz Mountains, California

26. Graphs showing mean 30-year monthly averages for precipitation, potential evapotranspiration, recharge, and runoff for current and two future projections for the Santa Cruz Mountains, California.

27. Map of redwood forest cover and area of average climatic water deficit suitable for redwood forest habitat in the Santa Cruz Mountains, California, $(A)$ for the historical period and $(B)$ projected for 2071-2100 in areas in which redwood forest currently lives, showing the middle 80 percent of the distribution and the upper and lower 10 percent tails

Appendix 2, figures A2-01 through A2-06: Cumulative Frequency of Basin Discharge for All Basins in the Santa Cruz Mountains, California 


\section{Tables}

1. Streamgages in the Russian River Valley, California, used for Basin Characterization Model (BCM) calibration and the calibration fit statistics...................24

2. Streamgages in the Santa Cruz Mountains, California, used for Basin Characterization Model (BCM) calibration and calibration fit statistics.

Appendix 1-1. Mean 30-year values for climate and water-balance components for current and four future projections for major water supply basins in the Russian River Valley, California

Appendix 3-1. Mean 30-year values for climate and water-balance components for current and four future projections for major water supply basins in the Santa Cruz Mountains, California 


\section{Conversion Factors}

SI to Inch/Pound

\begin{tabular}{lcl}
\hline \multicolumn{1}{c}{ Multiply } & By & \multicolumn{1}{c}{ To obtain } \\
\hline millimeter (mm) & Length & \\
meter (m) & 0.03937 & inch (in.) \\
kilometer $(\mathrm{km})$ & 3.281 & foot (ft) \\
meter (m) & 0.6214 & mile (mi) \\
millimeter per year per meter (mm/yr) & 1.094 & yard (yd) \\
\hline
\end{tabular}

Temperature in degrees Celsius $\left({ }^{\circ} \mathrm{C}\right)$ may be converted to degrees Fahrenheit $\left({ }^{\circ} \mathrm{F}\right)$ as follows:

${ }^{\circ} \mathrm{F}=\left(1.8 x^{\circ} \mathrm{C}\right)+32$

Vertical coordinate information is referenced to the North American Vertical Datum of 1988 (NAVD 88)

Horizontal coordinate information is referenced to the North American Datum of 1983 (NAD 83)

Altitude, as used in this report, refers to distance above the vertical datum.

\section{Abbreviations}

$\begin{array}{ll}\text { AET } & \text { actual evapotranspiration } \\ \text { BCM } & \text { Basin Characterization Model } \\ \text { CDIAC } & \text { Carbon Dioxide Information Analysis Center } \\ \text { CWD } & \text { climatic water deficit } \\ \text { DEHS } & \text { Department of Environmental Health Services } \\ \text { DOE } & \text { Department of Energy } \\ \text { E } & \text { Nash-Sutcliffe efficiency coefficient } \\ \text { EIA } & \text { International Energy Agency } \\ \text { GCM } & \text { Global Climate Model } \\ \text { GFDL } & \text { Geophysical Fluid Dynamics Laboratory CM2.1 model } \\ \text { GIDS } & \text { Gradient and Inverse Distance Squared } \\ \text { ID } & \text { identification } \\ \text { IPCC } & \text { Intergovernmental Panel on Climate Change } \\ \text { NCAR } & \text { National Center for Atmospheric Research } \\ \text { NOAA } & \text { National Oceanic and Atmospheric Administration } \\ \text { MODIS } & \text { Moderate-resolution Imaging Spectroradiometer } \\ \text { PCM } & \text { Parallel Climate Model } \\ \text { PET } & \text { potential evapotranspiration } \\ \text { PRISM } & \text { Parameter-Elevation Regressions on Independent Slopes Model } \\ \text { r } & \text { coefficient of determination } \\ \text { SSURGO } & \text { Solid Survey Geographic } \\ \text { STATSGO } & \text { State Survey Geographic } \\ \text { USGS } & \text { U.S. Geological Survey } \\ & \end{array}$


This page intentionally left blank. 


\title{
Simulation of Climate Change in San Francisco Bay Basins, California: Case Studies in the Russian River Valley and Santa Cruz Mountains
}

\author{
By Lorraine E. Flint and Alan L. Flint
}

\begin{abstract}
As a result of ongoing changes in climate, hydrologic and ecologic effects are being seen across the western United States. A regional study of how climate change affects water resources and habitats in the San Francisco Bay area relied on historical climate data and future projections of climate, which were downscaled to fine spatial scales for application to a regional water-balance model. Changes in climate, potential evapotranspiration, recharge, runoff, and climatic water deficit were modeled for the Bay Area. In addition, detailed studies in the Russian River Valley and Santa Cruz Mountains, which are on the northern and southern extremes of the Bay Area, respectively, were carried out in collaboration with local water agencies. Resource managers depend on sciencebased projections to inform planning exercises that result in competent adaptation to ongoing and future changes in water supply and environmental conditions.
\end{abstract}

Results indicated large spatial variability in climate change and the hydrologic response across the region; although there is warming under all projections, potential change in precipitation by the end of the 21st century differed according to model. Hydrologic models predicted reduced early and late wet season runoff for the end of the century for both wetter and drier future climate projections, which could result in an extended dry season. In fact, summers are projected to be longer and drier in the future than in the past regardless of precipitation trends. While water supply could be subject to increased variability (that is, reduced reliability) due to greater variability in precipitation, water demand is likely to steadily increase because of increased evapotranspiration rates and climatic water deficit during the extended summers. Extended dry season conditions and the potential for drought, combined with unprecedented increases in precipitation, could serve as additional stressors on water quality and habitat.

By focusing on the relationship between soil moisture storage and evapotranspiration pressures, climatic water deficit integrates the effects of increasing temperature and varying precipitation on basin conditions. At the fine-scale used for these analyses, this variable is an effective indicator of the areas in the landscape that are the most resilient or vulnerable to projected changes. These analyses have shown that regardless of the direction of precipitation change, climatic water deficit is projected to increase, which implies greater water demand to maintain current agricultural resources or land cover. Fine-scale modeling provides a spatially distributed view of locations in the landscape that could prove to be resilient to climatic changes in contrast to locations where vegetation is currently living on the edge of its present-day bioclimatic distribution and, therefore, is more likely to perish or shift to other dominant species under future warming. This type of modeling and the associated analyses provide a useful means for greater understanding of water and land resources, which can lead to better resource management and planning.

\section{Introduction}

The climate has been changing in California at a relatively rapid pace for at least a decade (2000-2010), particularly in comparison to the previous 50 years (Flint and Flint, 2012). These changes have resulted in hydrologic and ecologic effects across the state, such as earlier springtime snowmelt, increased numbers of extended dry periods (Lundquist and others, 2009), and regional shifts in species distribution (Hellman and others, 2004). Projected changes in regional air temperature and precipitation due to increases in global air temperatures are likely to result in changes in local hydrology that will require information specific to the San Francisco Bay area (Bay Area) to manage resources. Preparing for climate change in terms of water supply, water quality, flooding, drought, and habitat requires local and regional information regarding potential changes to climate and the response of the hydrologic system and ecosystems. For management applications and decision-making, this information needs to be based on the best science available at the basin scale. 
Understanding the effects of future climate projections at the basin scale required downscaling from the 2-degree (approximately 250-kilometers) spatial scale that Global Climate Models (GCMs) currently output. Downscaling refers to statistical techniques that take model output that have coarse scales (hundreds of kilometers) and generate relevant data to much finer scales (hundreds of meters) than the original. New approaches to downscale the climate model projections to very fine scales for air temperature and precipitation (Flint and Flint, 2012) provide an opportunity to apply them to physically-based models that are grounded in empirical basin data. This provides the means to assess potential future climate effects at meaningful hydrological and ecological scales. Downscaling to the basin scale provides local scale information for planning management exercises. The fine-scale application captures local climatic and topographic variability that can help identify zones of both basin vulnerability and resilience in the face of climate change.

For effective adaptive management, collection of realtime field data of basin indices that provide information about changing conditions is necessary for testing the hypotheses that are demonstrated here through both historical data and future climate projections. Basin-scale climate and hydrology projections represent a range of outcomes that include variability and spatial distributions that mimic historical climate patterns. Models can be used to estimate ranges of natural variability, project the direction and magnitude of decade to century trends, and quantify model uncertainty. Modeled scenarios do not provide forecasts, nor are they intended to capture short-term changes in weather; instead, they indicate potential or likely long-term trends by using realistic scenarios that provide reasonable ranges of possible hydrologic outcomes due to a warming climate.

In the context of global climate projections, the San Francisco Bay area is located in a transition zone between warmer and wetter winters projected for Oregon and Washington and warmer and drier conditions projected for Baja California and Mexico (Knowles and Cayan, 2002; Cayan and others, 2008, 2009). While average precipitation is not projected to shift toward a specifically wetter or drier climate, GCM scenarios were selected that span historic precipitation conditions. Study results illustrated how projected increases in air temperatures for Bay Area basins could affect the hydrologic cycle-particularly the relative volumes of evapotranspiration, runoff, and recharge for both "wetter" and "drier" outcomes.

Basin-scale studies in the Russian River Valley (fig. 1, Russian Basin) and Santa Cruz Mountains (fig. 1, San Lorenzo-Soquel Basin) on the northern and southern extremes of the Bay Area, respectively, have been carried out in collaboration with local water agencies. These studies were intended to develop science-based projections, which resource managers can use as a basis for informed planning exercises with the goal of effective adaptation to ongoing and future changes in water supply and environmental conditions.

\section{Purpose and Objectives}

The purpose of this report is to provide an assessment of the effects of climate change on hydrologic and ecologic resources in the San Francisco Bay Area with specific emphasis on the Russian River Valley and the Santa Cruz Mountains. The study approach was to downscale regional climatic data and a selection of four future climate projections based on two emissions scenarios and two GCMs and to apply the downscaled historical climate and future projections to a hydrologic model for the region. For this regional application, hydrologic model inputs were refined, the model was calibrated to measured data, and simulations were developed for 20th century and 21st century hydrologic and environmental conditions.

\section{Description of the Study Area}

Communities in the Bay Area rely on various water sources, including imported water, surface storage, and groundwater. Snowmelt is not a significant component of the water cycle for the Bay Area, but it is a large contributor to imported water from regions north of the Russian River and from the Sierra Nevada mountains to the east.

For this study, the Bay Area was geographically extended to include all basins that drain into the San Francisco Bay as well as those that have adjacent geopolitical boundaries. This was done to facilitate a regional approach to managing land and water resources (basin boundaries defined by U.S. Geological Survey 8-digit hydrologic unit codes; fig. 1). This extension included 19 basins that are a complex mosaic of land forms, vegetation types, and land uses, and range from densely forested to highly urbanized and from mesic (moist) to xeric (dry) habitats. Coastal climatic influences extend throughout the western portions of the Bay Area, where higher precipitation and fog are found along the coast and throughout the valleys, and drier and warmer conditions prevail closer to the Central Valley. Ecologically, the Bay Area is considered a "hotspot" of biodiversity because of climatic and geomorphic diversity of the region (Loarie and Ackerly, 2004).

The Russian River Valley ranges from sea level to 1,260 meters (m) and includes portions of Sonoma and Mendocino counties. The Russian River is the second largest river flowing through the 10 Bay Area counties (the largest is the Sacramento River) and has a 177-kilometers (km) long mainstem. It is also home to the endangered Coho salmon, which has resulted in mandatory flow regulations to maintain minimum streamflows. Warm Springs Dam, built in 1982, and Coyote Dam, built in 1959, are the primary tools for controlling flow. The valley floor and many hillsides are dominated by wine grape agriculture. 


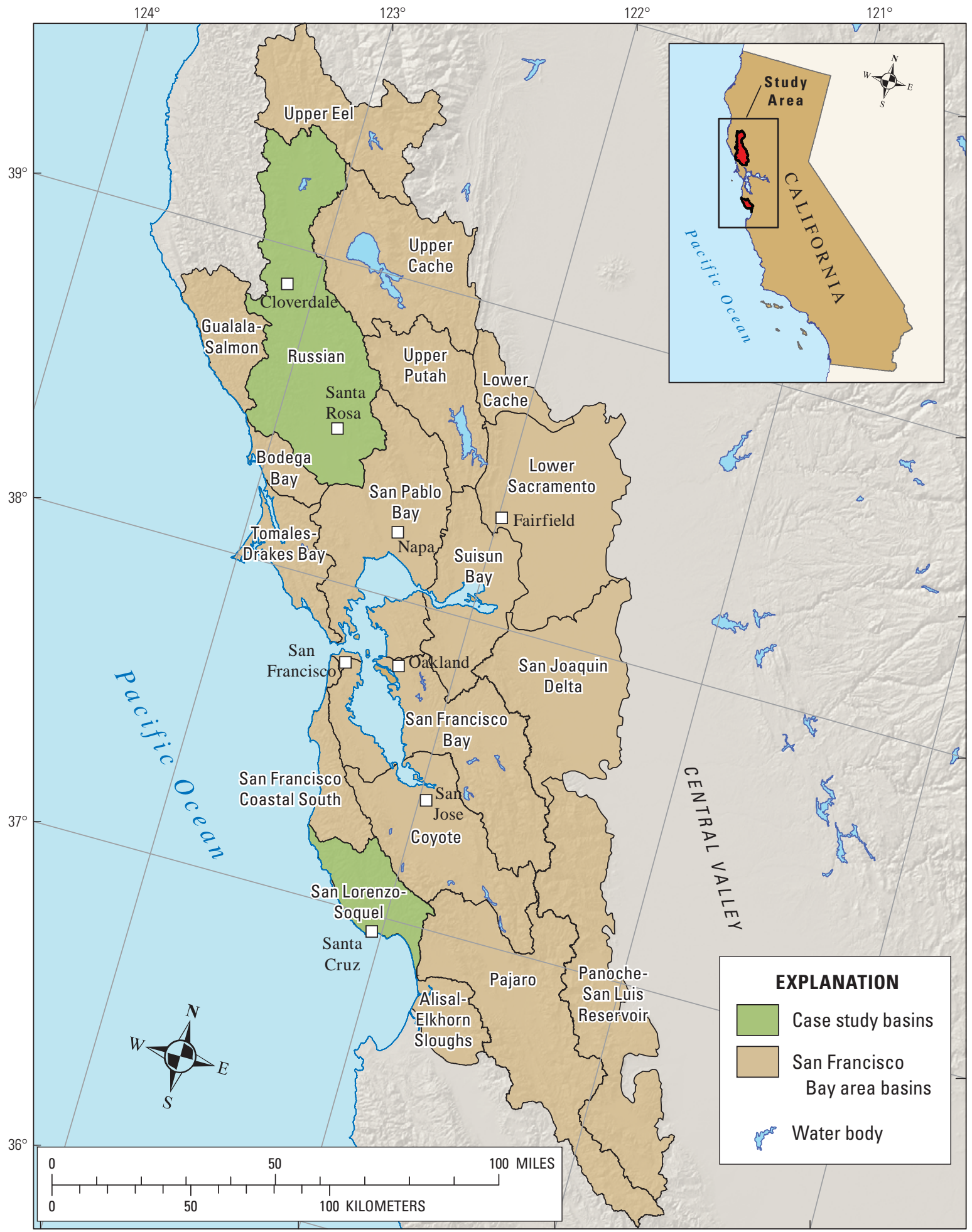

Digital elevation model from National Elevation Database, CAGIS, 2011

Figure 1. San Francisco Bay Area, California, basins. 
The Santa Cruz Mountains reside within Santa Cruz county and parts of San Francisco, San Mateo, Santa Clara, San Benito, and Monterey counties. For this study, only the basins that drain to the urbanized area around the city of Santa Cruz were considered for detailed analysis. The study area ranges from sea level to $1,150 \mathrm{~m}$ and has an average annual precipitation of 672 millimeters (mm), of which about 69 $\mathrm{mm}$ falls as snow. Like the Russian River Valley, this area is known for wine grape agriculture as well.

\section{Characteristics of Bay Area Climate}

Monthly climate data averaged for 1971-2000 for the Bay Area show high spatial and temporal variability (fig. 2). Average precipitation, and maximum and minimum air temperature from Parameter-Elevation Regressions on Independent Slopes Model (PRISM, a gridded climate dataset developed by Daly and others, 2004) are shown in figure $2 \mathrm{~A}$ for the Bay Area and illustrate the transition of cool and wet in the west to warm and dry in the east. Both the Russian River Valley and Santa Cruz Mountains basins receive more precipitation and have lower minimum air temperatures than most of the basins in the Bay Area. The Russian River and Santa Cruz basins also exhibit warmer maximum air temperatures than the coastal areas north of the Bay.

To illustrate general geographic patterns of climate change from 1971 to 2000, a linear regression was applied to the downscaled PRISM data added into water years for every grid cell (270-m) to calculate the magnitude and direction of observed changes in precipitation and air temperature (fig. 2B). The PRISM dataset has not been corrected for new and terminated stations or changes in measurement methods over time, which can lead to inaccuracies in the long-term changes depicted in spatial maps as well as in temporal changes in areally averaged climate. This analysis of climate trends from 1971 to 2000, however, is intended to demonstrate general spatial heterogeneity in climate change over time and to establish a baseline for future changes in climate in this region. The climate, represented by precipitation, and maximum and minimum air temperatures, changed during this period and continues to show variability, such that some areas have warmed and others have cooled. Increased precipitation is indicated along the entire coast and into the Russian River Valley, whereas eastern locations and the south bay had reduced precipitation. The distinct variability in the climatic changes indicates topographic controls that influence local climate patterns, such as adiabatic lapse rates, cold-air pooling, and shading from solar radiation, that could persist into the future and provide management opportunities.

\section{Methods}

\section{Climate Change Projections}

Global future climate projections created though the application of GCMs and distributed by the Intergovernmental Panel on Climate Change (IPCC) estimate future spatial patterns of temperature and precipitation in response to greenhouse gas forcing. GCMs generally are available for the continental United States at 2-degree spatial resolution (approximately 250-km resolution for the Bay Area; Intergovernmental Panel on Climate Change, 2001, 2007). A set of these projections has been downscaled to 12-km for the United States by researchers at the U.S. Geological Survey (USGS) and Scripps Institute of Oceanography by using the constructed analogs method of Hidalgo and others (2008). This method is a deterministic, linear approach that relies on the spatial patterns of historical climate data. The downscaling method of constructed analogues demonstrates a high level of skill, whereby it captures an average of 55 percent of the variance of measured monthly precipitation anomalies for the United States and more than 80 percent of the variance of average air temperature monthly anomalies (Hidalgo and others, 2008). These statistically downscaled $12-\mathrm{km}$ projections provided a basis for the spatial downscaling that was done in this study for basin-scale model application for the Bay Area.

The choice of models and emission scenarios was based on global climate models that have proven capable of simulating recent historical climate for California, particularly in terms of the distribution of monthly temperatures and the strong seasonal cycle of precipitation (Cayan and others, 2008, 2009). In addition, models were selected to represent a range of model sensitivity to greenhouse gas forcing. On the basis of these criteria, two GCMs were selected from among the IPCC models: the Parallel Climate Model (PCM), developed by National Center for Atmospheric Research (NCAR) and Department of Energy (DOE; see Washington and others, 2000; Meehl and others, 2003), and the National Oceanic and Atmospheric Administration (NOAA) Geophysical Fluid Dynamics Laboratory (GFDL) CM2.1 model (Stouffer and others, 2006; Delworth and others, 2006). The A2 greenhouse gas emissions scenario is defined as a medium-high scenario, where no changes are made in the current policies that affect carbon emissions. The B1 scenario represents a low, "mitigated emissions" scenario, where reductions are made to carbon emissions. These scenarios were based on implementation decisions made by the IPCC and are described in more detail in Nakićenović and others (2000). These models 


\section{A}

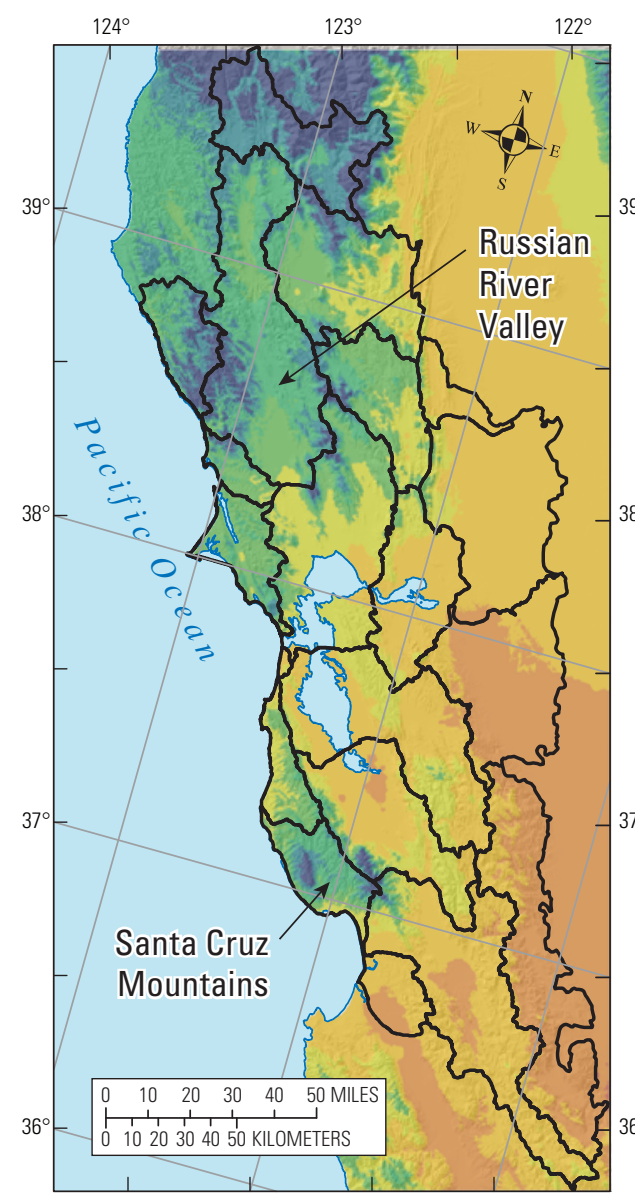

PRECIPITATION, IN MILLIMETERS PER YEAR

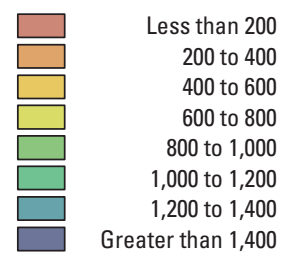

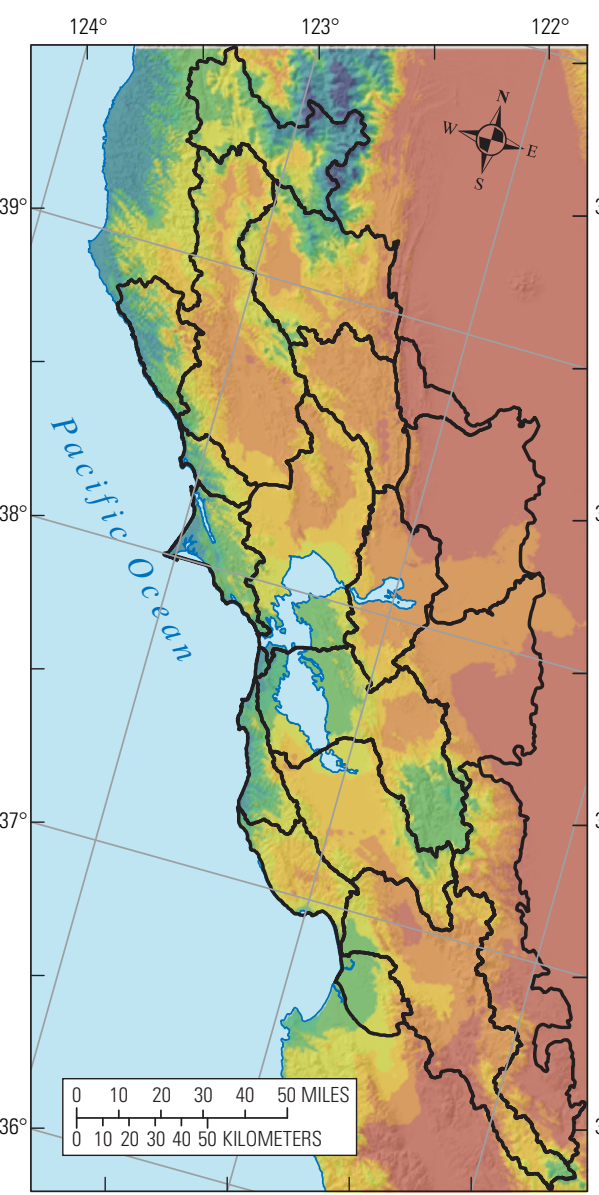

\section{EXPLANATION}

AVERAGE MAXIMUM AIR TEMPERATURE, IN DEGREES CELSIUS

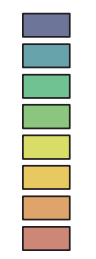

Less than 16

16 to 18

18 to 19

19 to 20

20 to 21

21 to 22

22 to 23

23 to 24

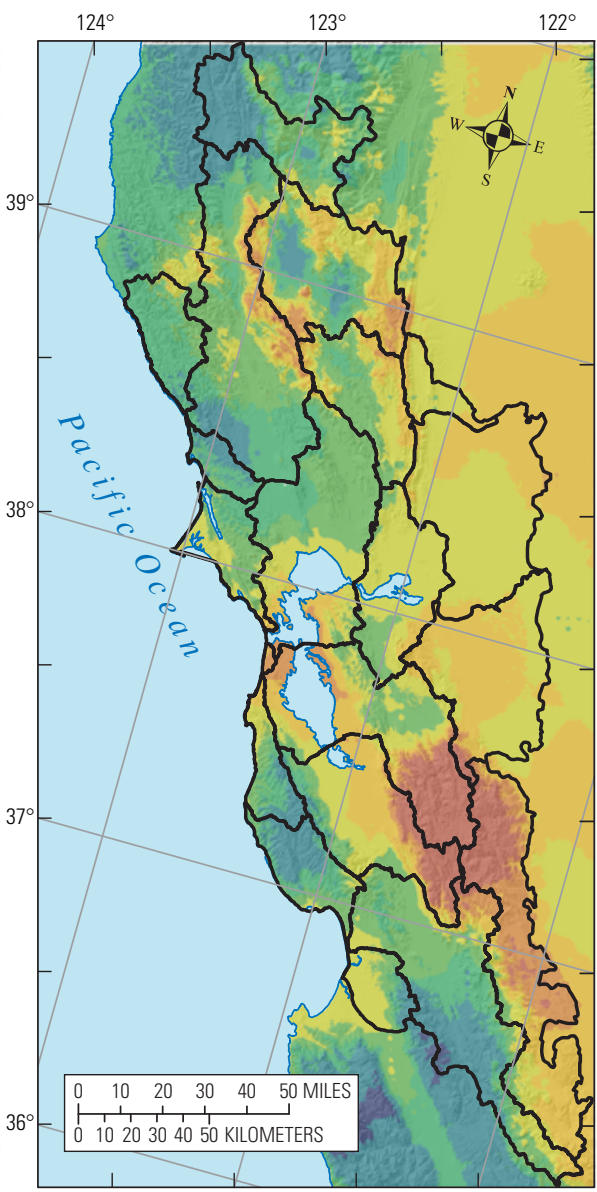

AVERAGE MINIMUM AIR TEMPERATURE, IN DEGREES CELSIUS

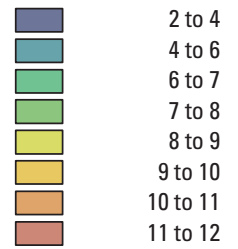

\}दु San Francisco Bay

Figure 2. Spatially distributed average annual precipitation, maximum air temperature, and minimum air temperature for San Francisco Bay area, California, basins $(A)$ during 1971-2000, and $(B)$ change in annual averages between 1971 and 2000. 
B

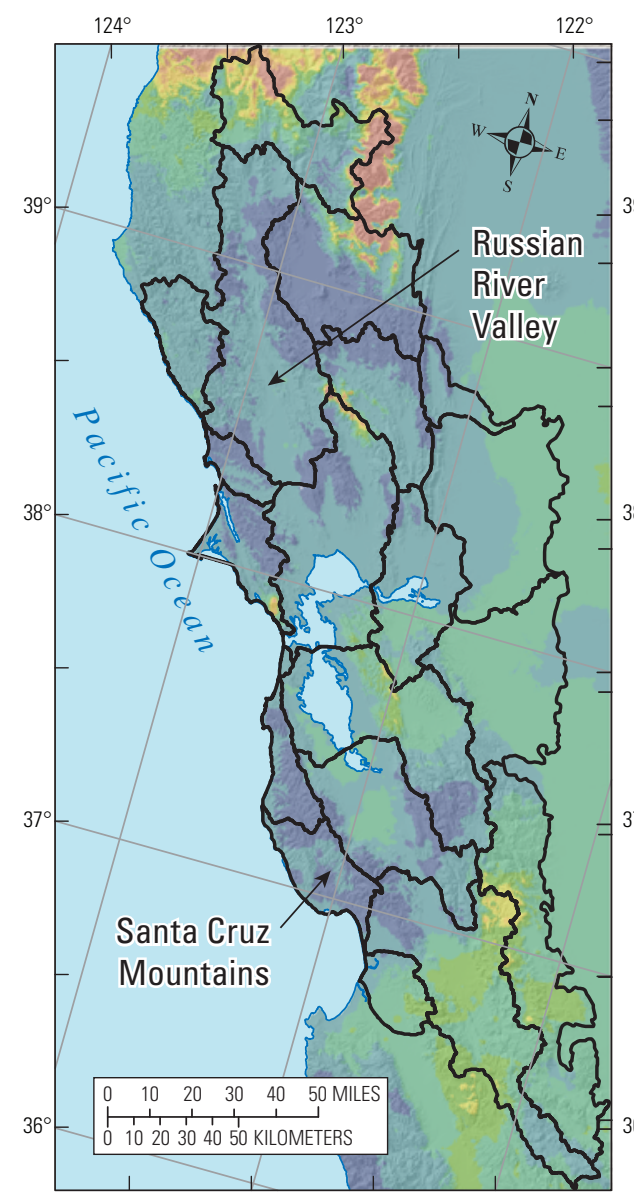

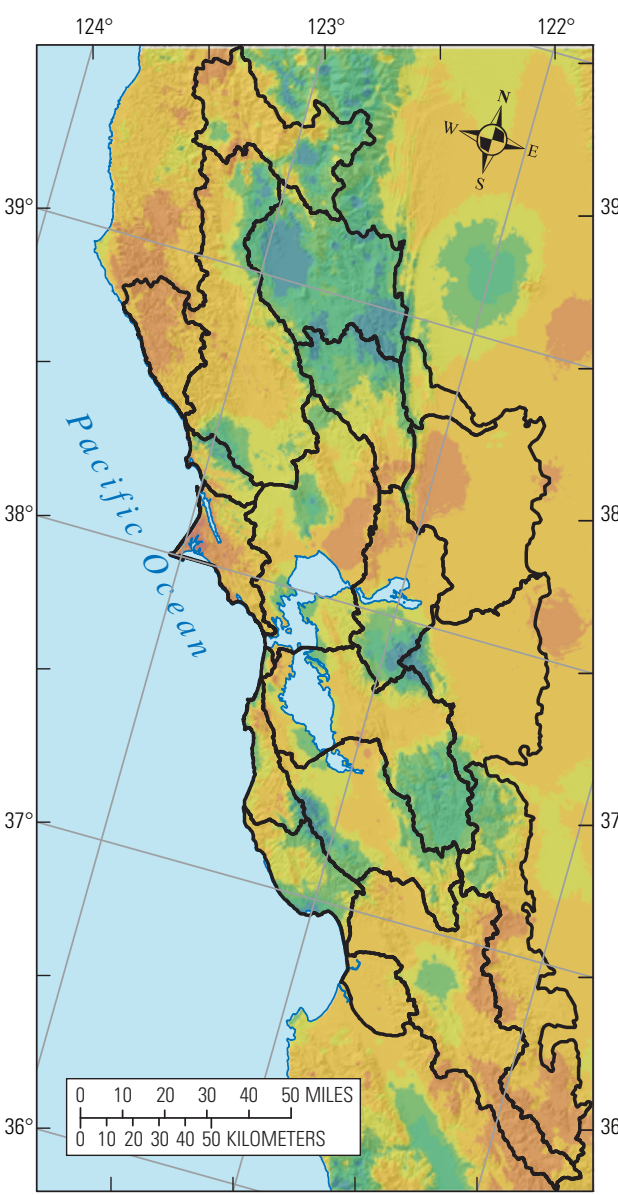

EXPLANATION

CHANGE IN PRECIPITATION, IN MILLIMETERS

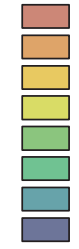

CHANGE IN MAXIMUM AIR TEMPERATURE,

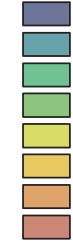

-2 to -1

-1 to -0.5

-0.5 to -0.1

-0.1 to 0.1

0.1 to 0.5

0.5 to 1

1 to 2 IN DEGREES CELSIUS

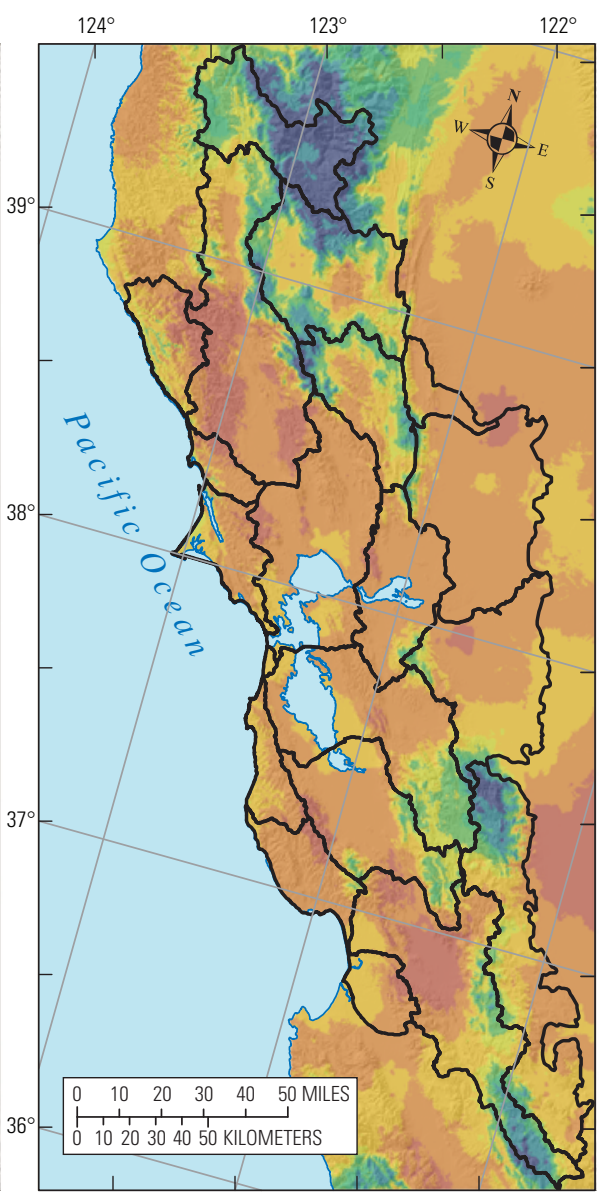

CHANGE IN

MINIMUM AIR TEMPERATURE, IN DEGREES CELSIUS Sf San Francisco Bay
area basins

Figure 2.-Continued 
tended to project conditions in California that are warm and wet (PCM) or even warmer and dry (GFDL). The suite of currently available emission scenarios as well as currently measured greenhouse gas emission rates are presented in figure 3, which shows that the A2 scenario is only more moderate than the fuel-intensive A1Fi scenario, and the B1 scenario is the most optimistic about future global greenhouse gas emissions. By using these scenarios, a range of climatic projections ensue. In this study, the two models projected two emissions scenarios each, which are abbreviated in this report as "GFDL-A2," "GFDL-B1," "PCM-A2," and "PCM-B1." Of the two scenarios used in this study, the A2 scenario most accurately reflects the measured data and was used in the model simulations.

\section{Basin Characterization Model}

Water-balance modeling can be used to determine the flow of water in and out of a basin. It can be used to evaluate spatially distributed basin variables, including precipitation, evapotranspiration, surface water runoff, infiltration, and groundwater recharge. A water-balance model was developed to reconstruct historical basin conditions and future conditions for scenarios in the Russian and San Lorenzo-Soquel (Santa Cruz Mountains) basins. Output from the model was used to evaluate effects of climatic changes on the hydrology of these basins for the historical period of the 20th century, 1900-2000, and the 21st century, 2000-2100.

The Basin Characterization Model (BCM) was used in this study to simulate basin conditions in the Russian River Valley and Santa Cruz Mountains. The BCM is a physicallybased model that uses gridded data to calculate water-balance components on the basis of data inputs for topography, soil composition and depth, underlying bedrock geology, and spatially-distributed values (measured or estimated) of air temperature and precipitation (Flint and Flint 2007a, 2007b). The BCM relies on a rigorous hourly energy-balance calculation using topographic shading, precipitation, and air temperature data to simulate potential evapotranspiration, which is aggregated to monthly values. Historical climate data were from the empirically-based PRISM monthly precipitation and air temperature database and maps (Daly and others, 2004). Maps of surface geology were used to estimate bulk bedrock and alluvium permeability (fig. 4), and available soil water content (fig. 5) was calculated from Solid Survey Geographic (SSURGO) soil databases of soil thickness, water content at wilting point and field capacity, and soil porosity (Natural Resources Conservation Service, 2006).

The BCM is calibrated regionally to measured potential evapotranspiration data and Moderate-resolution Imaging Spectroradiometer (MODIS) snow cover data (Flint and Flint, 2007b; Flint and others, 2011). Locally, the model also is calibrated to measured unimpaired streamflow data. The determination of whether excess water becomes recharge or runoff is governed in part by the underlying bedrock permeability. The higher the bedrock permeability, the higher the recharge and the lower the runoff calculated for a given grid cell. In small, gaged basins that have unimpaired flows, the bedrock permeability can be adjusted to calculate a total basin discharge that matches the measured basin discharge. The BCM does not route streamflow from grid cell to grid cell, but it can be used to identify locations and climatic conditions that produce excess water by quantifying the amount of water available as either runoff or recharge for each grid cell on a monthly basis. Post-processing is used to calibrate recharge and runoff for specific basins to account for gaining and losing streams and to match measured streamflow and estimate basin discharge. Because the model does not include basin or stream impairments, diversions, or urban runoff, the comparison between the calculated basin discharge from the model and the actual measured streamflow in these locations are de-emphasized in the calibration process.

Temperature and precipitation are two primary drivers of physical processes acting at the basin scale. BCM hydrologic variables sensitive to temperature include potential evapotranspiration (PET) and actual evapotranspiration (AET). BCM output parameters that are sensitive to quantities of precipitation include runoff and recharge. Climatic water deficit (CWD), defined in more detail in later sections, combines the effects of precipitation, temperature, solar radiation, and potential evapotranspiration by tracking changes in soil moisture over time.

The BCM is run in FORTRAN at the same resolution (grid size) as the digital elevation model, which is $270 \mathrm{~m}$ for the Bay Area, and requires that the geology and soils inputs, as well as the historical and future time series of grids of monthly climatic parameters, have the same grid size and grid points. Because of the fine scale of this model application, fine-scale differences in solar radiation, potential evapotranspiration, and soil properties can be resolved to the extent that such properties are known or can be estimated (such as north or south facing hillslopes and channel bottoms or ridgetops), thereby providing a more realistic and useful hydrologic interpretation.

\section{Downscaling Climate Data for Model Application}

Monthly-averaged precipitation and air temperature are available in a gridded map formatted at a 4-km spatial scale from PRISM for historical time spans from 1896 through 2009 (Daly and others, 2004). Spatial downscaling of the climate data was performed on coarse, 4-km resolution grids to produce fine, 270-m resolution grids. The approach used a model developed by Nalder and Wein (1998) that applies a spatial gradient and inverse distance squared (GIDS) weighting to monthly point data by developing multiple regressions for each fine-resolution grid cell for every month. By using the PRISM climate parameters and the 4-km resolution digital elevation model, parameter weighting is 


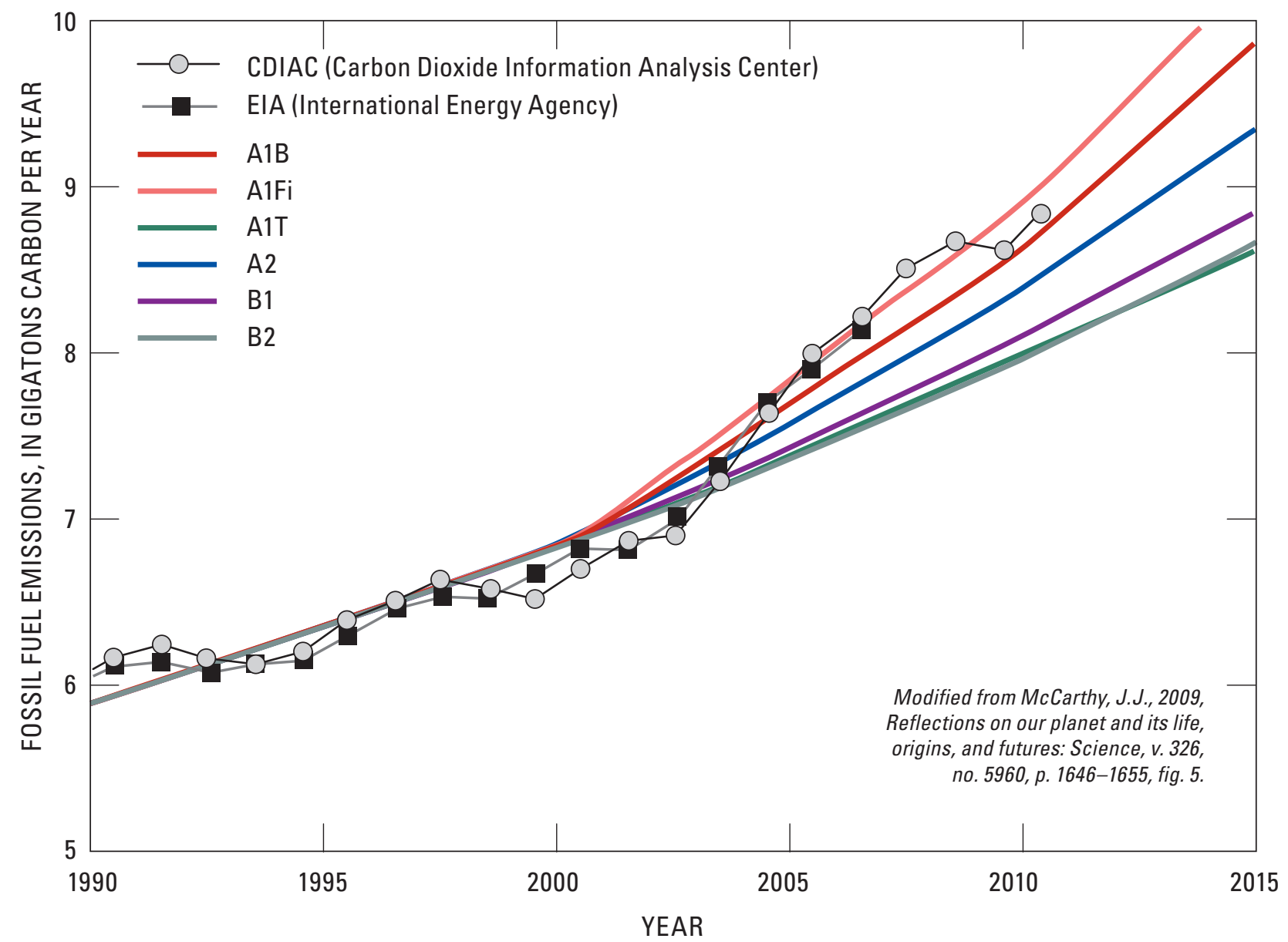

Figure 3. Measured global carbon dioxide $\left(\mathrm{CO}_{2}\right)$ emissions compared to Intergovernmental Panel on Climate Change (IPCC) emissions scenarios.

based on the location and elevation of the coarse-resolution cells surrounding each fine-resolution cell (Flint and Flint, 2012) to predict the climate parameter at the fine-resolution cell. To remove the "bullseye" effect often associated with certain interpolation schemes (that is, kriging, inverse distance squared, and others), the program was modified to have a search radius that is specified as equal to or greater than the size of the coarse-scale grid cell. For example, for the 12-km to 4-km downscaling, the search radius was set to $12-\mathrm{km}$; whereas, for the 4-km to $270-\mathrm{m}$ downscaling, the search radius was set to 4-km.

Global climate models simulate the baseline current climate (1950-2000) with no elevated carbon dioxide $\left(\mathrm{CO}_{2}\right)$ emissions and use various emissions beginning in 2000 to project the future climate. The model projections are trends in climate; they are not calibrated to match current climate, which results in a bias. To correct this bias so that the future projected trend begins at current climate conditions, the dataset requires adjustment so that the mean and standard deviation of the historical climate simulation matches measured climate for the baseline period. The baseline period for this study is defined as the PCM and GFDL model runs for
1950-2000, when climate change forcings are assumed absent from the model and, thus, represent pre-2000 atmospheric greenhouse gas conditions.

GCM projections represent trends in climate variables and do not necessarily match current climate. This bias needs to be corrected to reflect the current climate by using measured data. The four future climate projections were downscaled from the 12-km grid scale to $4 \mathrm{~km}$ in order to use the historical PRISM dataset for the purpose of bias correction. Figure 6 shows an example of selected grid scales of maximum air temperature for June 2035 for the Bay Area. The simulations for the baseline period were compared to the PRISM data from 1950-2000; for each month and for each grid cell, the scaling values were developed by following the method of Bouwer and others (2004). This method is described in detail in Flint and Flint (2012). Note that the dataset was adjusted so that baseline simulations matched the mean and standard deviation of the historical data. Once the bias correction was completed, the adjusted 4-km projections were further downscaled to a 270-m spatial resolution, as shown in fig. 6, by using the GIDS spatial interpolation approach for model application. 


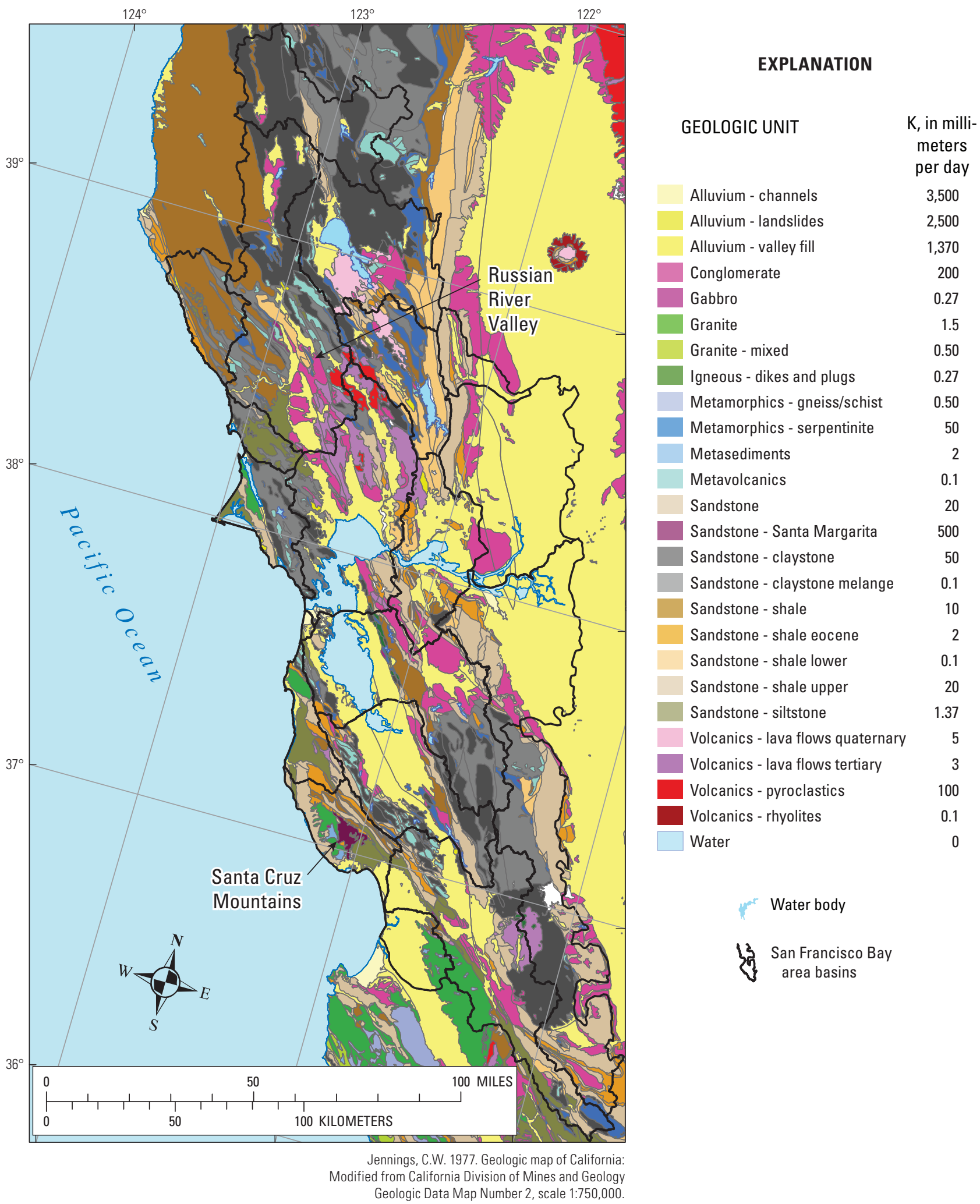

Figure 4. Surface geology and associated estimates of surficial bedrock permeability (K) for basins in the San Francisco Bay Area, California. 


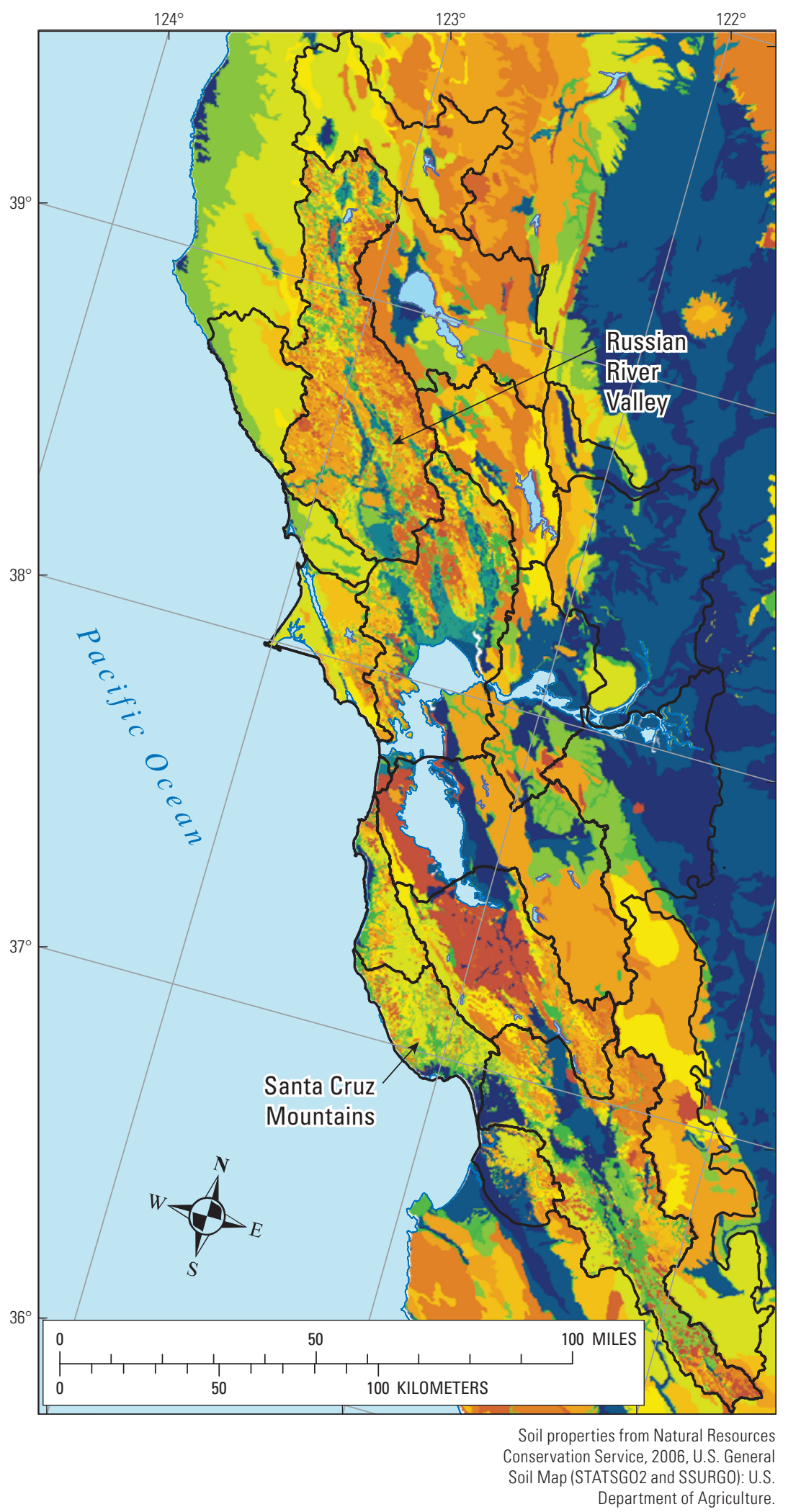

\section{EXPLANATION}

AVAILABLE WATER CONTENT, IN METERS

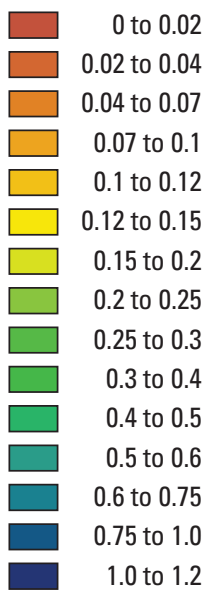

Water body

If San Francisco Bay

Figure 5. Total soil available water content (calculated at field capacity minus water content at wilting point multiplied by soil depth) for basins in the San Francisco Bay Area, California. 

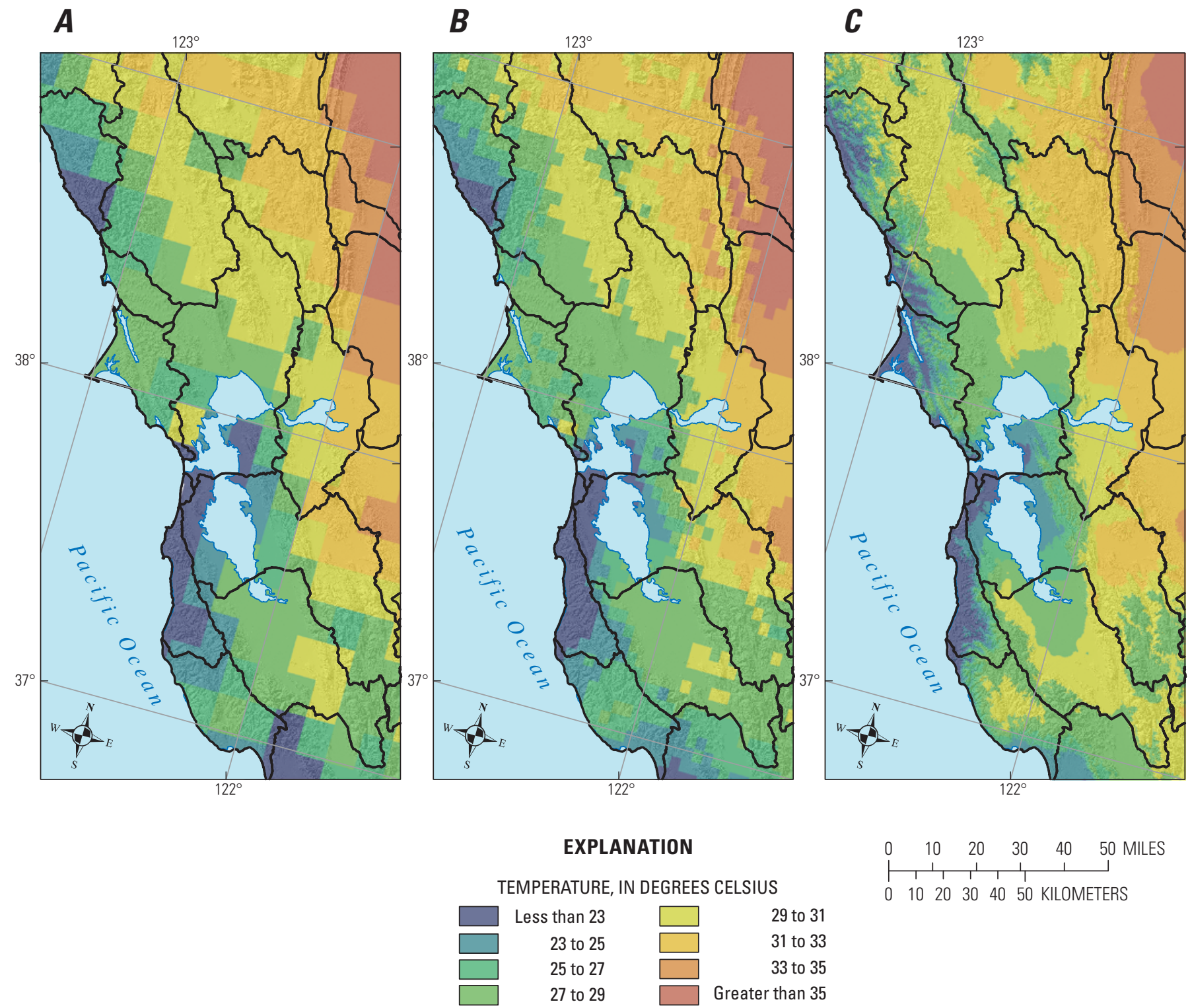

$\begin{array}{llllll}0 & 10 & 20 & 30 & 40 & 50 \\ \text { KILOMETERS }\end{array}$ resolutions of $(A)$ 12-kilometers $(\mathrm{km}),(B)$ 4-km, and (C) 270-meters.

\section{Calibration to Measured Streamflow}

Calibration of the BCM has been done regionally for the southwestern United States (Flint and others, 2010). To match basin discharge, regional geology maps were used to estimate the bulk bedrock permeability that partitions excess water into recharge and runoff. For the Bay Area, several geologic units were refined within existing layers to provide additional geologic resolution, including the subdivision of sandstone-claystone units to include claystone mélange having lower bulk bedrock permeability, the sub-division of sandstone-shale units to include Eocene and upper and lower units that have different physical properties and permeability, and the subdivision of lava flows into quaternary and tertiary units to allow for more variation in permeability across the volcanics (fig. 4). These refinements allowed the model to be more accurately calibrated to streamgages. Also, addition of SSURGO soils data to the Russian River Valley and the Santa Cruz Mountains provided finer spatial resolution for soil properties in those areas. The thickness of the soil ranged from 0 to $6 \mathrm{~m}$ in the Bay Area basins. Calibration of streamflow was achieved by adjusting the bedrock permeability, which can change the proportion of excess water that becomes recharge or runoff. 
The BCM does not include any water routing diversions or extractions, and therefore, comparison to measured streamflow must be on unimpaired streams - streams that are not subject to diversions, urban runoff, or agricultural withdrawals. Runoff and recharge are calculated in monthly time steps and compared to monthly measured streamflows. Soil and bedrock permeability were adjusted until the measured monthly volume for the period of record matched the BCM estimated discharge to within 5 percent. The local calibration procedure for each basin used the accumulated monthly runoff, $B C M_{\text {run }}$, and recharge, $B C M_{r c h}$, calculated by the BCM for all grid cells upstream of the streamgage. The total monthly recharge and runoff for all grid cells were used to calculate basin discharge to compare to measured streamflow. To account for stream channel losses and gains, a multiplier, Run scaler, that reduces runoff in order to better match peak flows and attempt to simulate loss of runoff to losing streams, was employed in the following:

$$
\text { Runoff }=\left(B C M_{\text {run }(i)} * \text { Run }_{\text {scaler }}\right)
$$

To calculate baseflow ( $\left.G W_{\text {shallow }}\right)$ that will extend streamflow through the dry season, the recharge values were accumulated and an exponent, ranging from 0.900 to 0.997 , was used to create recession and calibrate to low flows. Generally, regions with low summer flows, such as arid environments, have smaller baseflow exponents; whereas regions with larger groundwater components, such as the volcanics in the upper Klamath basin, have larger baseflow exponents. Finally, to simulate loss of recharge to the groundwater system, a multiplier, $R c h_{\text {scaler }}$, is used to reduce the recharge component that makes it to the streamgage:

$$
G W_{\text {shallow }}=\left[\left(B C M_{\text {rch }(i-1)}+B C M_{\text {rch }(i)}\right)^{\text {Exp }}\right] * R c h_{\text {scaler }}
$$

This value is generally very small in desert areas that have deep unsaturated zones and high in large basins with high baseflows. This allows for deep groundwater flow, $G W_{\text {deep }}$, to be estimated as follows:

$$
\begin{gathered}
G W_{\text {deep }}=\left[B C M_{\text {run }(i)} *\left(1-\text { Run }_{\text {scaler }}\right)\right]+ \\
{\left[\left(B C M_{r c h(i-1)}+B C M_{r c h(i)}\right)^{E x p} *\left(1-\text { Rch }_{\text {scaler }}\right)\right]}
\end{gathered}
$$

This equation is analogous to the recharge equation used in some groundwater flow models. Total basin discharge in the model is calculated by the following:

$$
\text { Discharge }=\text { Runoff }+G W_{\text {shallow }}
$$

The coefficients are iteratively adjusted to optimize the match between measured streamflow and calculated basin discharge and to increase the monthly coefficient of determination, $\mathrm{r}^{2}$; the yearly summed $\mathrm{r}^{2}$; and the NashSutcliffe efficiency coefficient, E (Nash and Sutcliffe, 1970). The Nash-Sutcliffe coefficient has been widely used to evaluate the performance of hydrologic models (Legates and McCabe, 1999) and is calculated as one minus the mean square error divided by the variance. As an absolute measure, rather than a squared difference, this coefficient is more conservative and provides a better way to compare goodnessof-fit for locations with widely different discharges. It is sensitive to differences in the observed and model-simulated means and variances, but is generally overly sensitive to extreme values, as is $\mathrm{r}^{2}$. If goodness-of-fit was not unique to a set of coefficients, the calibration was generally optimized to favor lower flow conditions for both the Russian and Santa Cruz models. All calibration parameters used to produce best fits between simulated and measured basin discharge were then used with simulated recharge and runoff to calculate future basin discharge.

\section{Results and Discussion of Model Simulations}

\section{Bay Area Trends}

Decadal (10-year) averages of precipitation and maximum air temperature in the Bay Area showing historical and future climate generated by the GCMs are presented in figure 7. The long term variability in precipitation is demonstrated by droughts in the 1920s, the 1970s, and the late 1990s. Maximum air temperature in the Bay Area has steadily risen over the last century by 1 degree Celsius $\left({ }^{\circ} \mathrm{C}\right)$, and all model and scenario projections indicate it will continue to rise. Projections of precipitation differed between models; the PCM model generally showed higher precipitation, and the GFDL model generally indicated lower, regardless of emissions scenario. The air temperature projections for the 21st century showed increases from 2 to $4^{\circ} \mathrm{C}$ in the Bay Area, but the B1 emissions scenario estimates were less than from the A2 scenario. It is worth noting that this range is well within historical variability of air temperature for most locations in the Bay Area, but also that persistence in habitats and species is unlikely to be correlated to variability in temperature. Instead, habitats and species are more likely to adapt and persist on the basis of long term average air temperatures.

The projected increases in variability of precipitation under the A2 scenario and the projected rise in air temperature are demonstrated by 30-year averages for 1911-2100 (fig. 8). Because a larger standard deviation conveys greater variability, and a wider range indicates greater extremes, in figure 8, the Bay Area study area as a whole shows the greatest variability and range in precipitation and maximum air temperature during this period ( fig. $8 A$ ); the Russian River Valley shows the least variability (fig. $8 B$ ), but its range in 

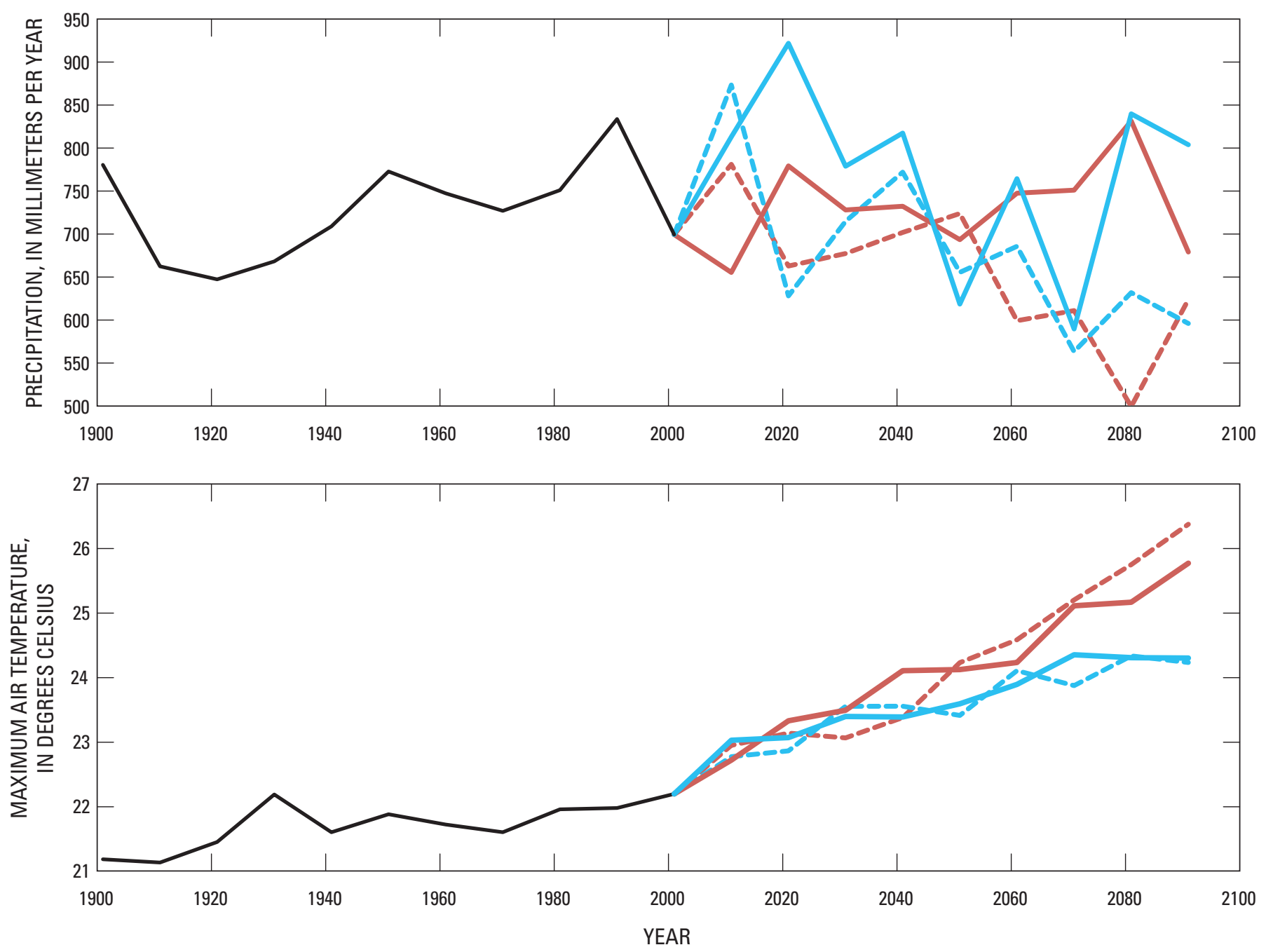

EXPLANATION

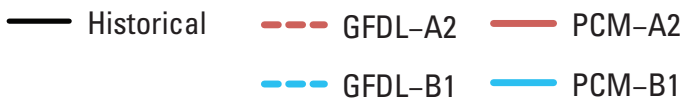

Figure 7. Historical climate and four projections shown by decadal (10-year) average precipitation and maximum air temperature for basins in the San Francisco Bay Area, California.

both precipitation and maximum air temperature exceed that of the Santa Cruz Mountains, which generally shows greater variability but lesser extremes (fig. $8 \mathrm{C}$ ). It is likely that the Russian River Valley, which is inland from the coast, is subject to more variability in precipitation due to the orographic effects on precipitation, whereas coastal climate conditions likely moderate variability in the Santa Cruz Mountains. The average maximum air temperature is lower in the Santa Cruz Mountains compared to the Russian River Valley because of its proximity to the coast. While there is little difference in the upper and lower range of the precipitation for the Santa Cruz Mountains, the Russian River Valley has a longer tail to the upper extreme, indicating that this area receives a greater number of storms characterized by above average conditions than the Santa Cruz Mountains. In both areas, air temperature tails are skewed low, indicating periodic extremes in low temperature, in contrast to high temperature. Projected precipitation in all basins increases slightly for the PCM model and decreases for the GFDL model, while maximum air temperature increases in all projections. Based on these 30-year averages, there is no evidence for changes in variability over time in the region, but the low precipitation coinciding with the historic drought of the 1930s is realized in the GFDL-A2 projection for the end of the century for all locations, especially Santa Cruz. 
A

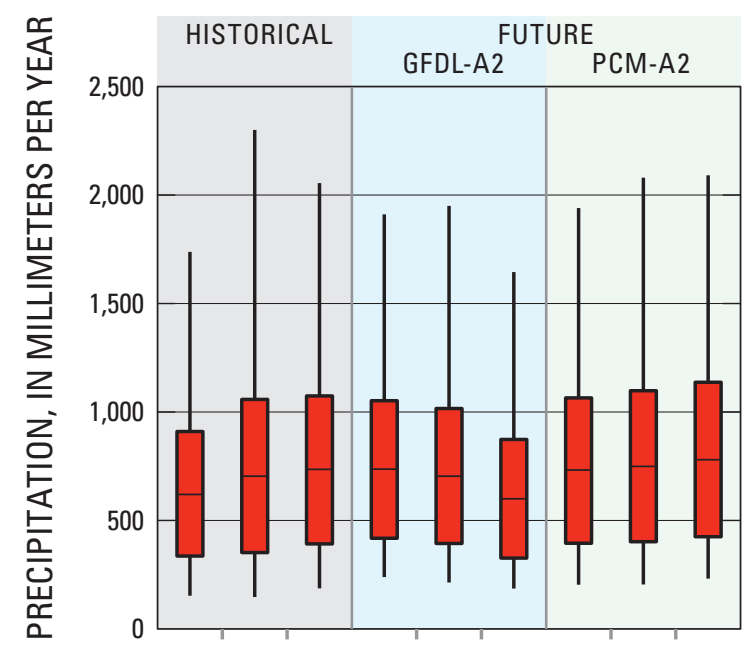

B

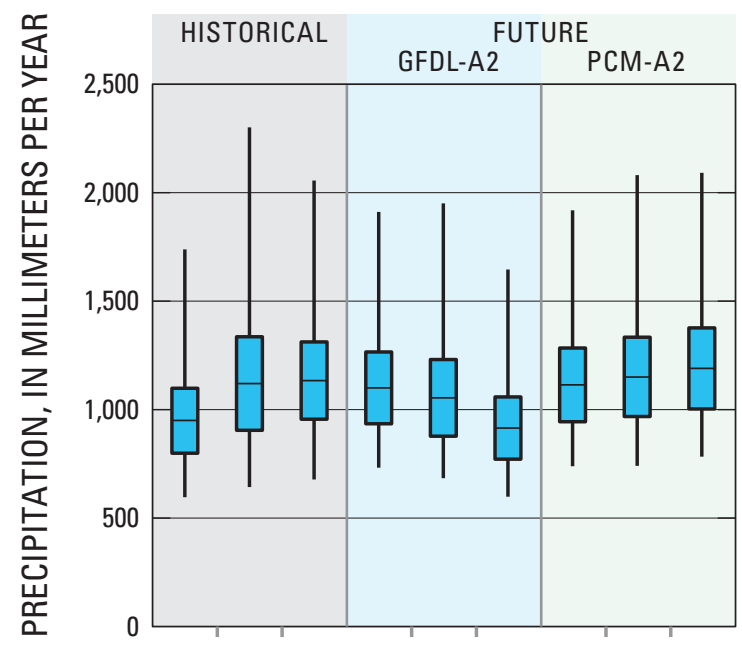

C

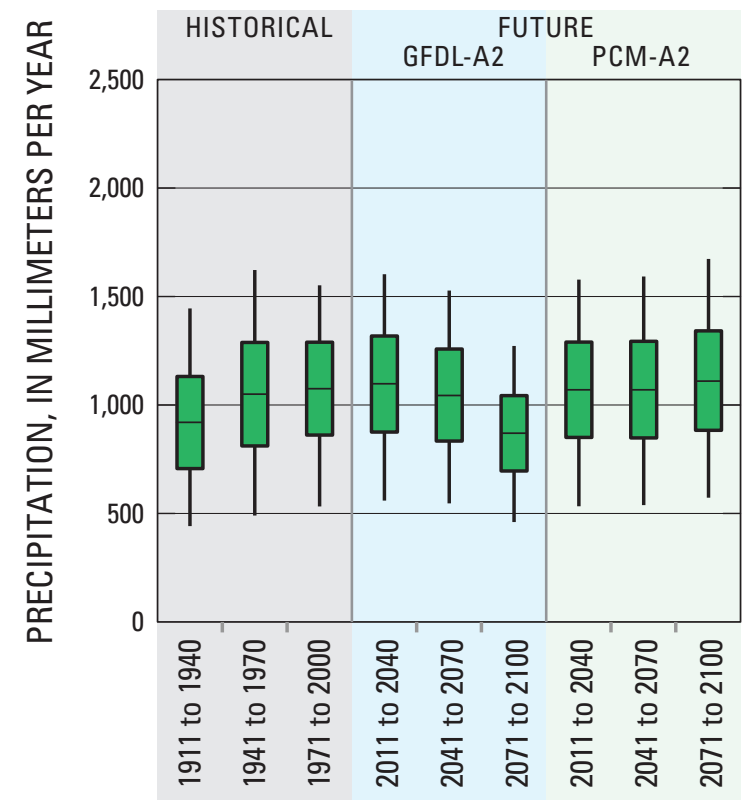

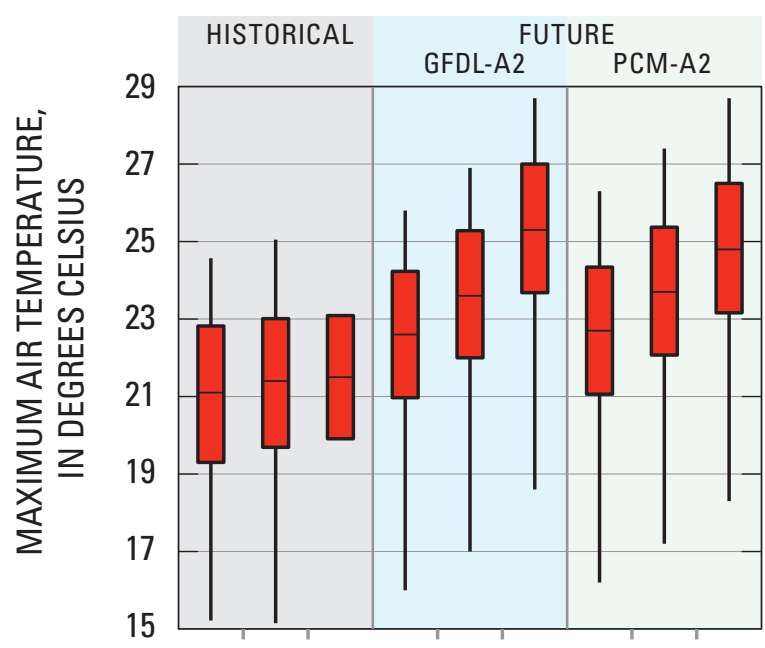
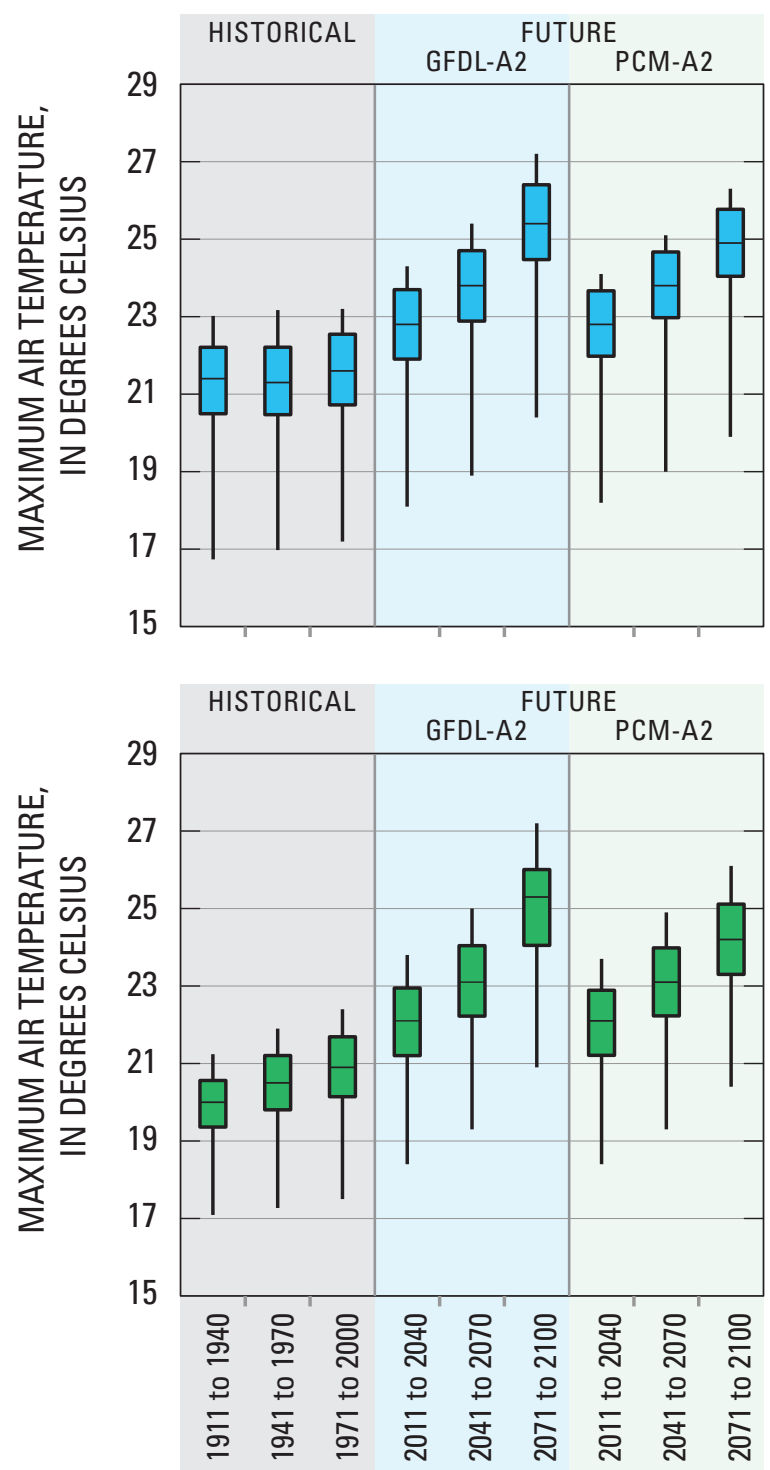

Figure 8. Historic and projected precipitation and maximum air temperature depicted with 30-year histograms for 1911-2100 under the A2 scenario for the $(A)$ entire San Francisco Bay Area, $(B)$ Russian River Valley, and $(C)$ Santa Cruz Mountains. The horizontal black bar represents the mean, the boxes represent the standard deviation, and the tails represent the range around the mean. 
The sequence of maps shown in figure 9 depicts the average spatial distribution of runoff and recharge for the historical period (1971-2000; fig. 9A), and the difference between 1971-2000 and 2071-2100 for runoff and recharge in $\mathrm{mm} /$ year for the two models under the A2 scenario (fig. 9B). Model calibrations for these BCM results are discussed in the following sections describing the hydrologic model results for the Russian River Valley and Santa Cruz Mountains. Figure $9 A$ shows the northern basins are dominated by runoff, whereas the southern coast is dominated by recharge. Little to no runoff or recharge is generated in the Central Valley or in large valley basins because excess water is stored in the deep soils.

The maps showing the change in runoff and recharge by the end of the 21st century ( $f g .9 B$ ) illustrate the relative vulnerability and resilience of the basins to future changes in climate. Vulnerability is indicated by locations that have large changes in hydrologic response to change in climate, whereas resilience is indicated by locations that have little change in hydrologic response to change in climate.

The most notable difference among the maps is between models where the PCM projects less hydrologic response than the GFDL (fig. 9B), which supports earlier observations. There are subtle trends in the mountains of the region that could lead to dramatic changes in runoff or recharge. Declines in runoff and recharge for the GFDL model are particularly large in the mountains of the northern basins, where they reach 300 millimeters per year ( $\mathrm{mm} / \mathrm{yr}$ ), and along the coast in the mountains near Santa Cruz, where there are decreases of nearly $250 \mathrm{~mm} / \mathrm{yr}$ (fig. 9B). Even the PCM model, which projected a general increase in precipitation, shows declines in recharge up to $200 \mathrm{~mm} /$ year in the Santa Cruz area.

The CWD is defined by Stephenson (1998) as the amount by which potential evapotranspiration (PET) exceeds actual evapotranspiration (AET). It integrates the effects of solar radiation, evapotranspiration, air temperature, and precipitation to calculate changes in soil moisture and AET. CWD can be thought of as the amount of additional water present in the soils that would evaporate or transpire in response to temperature forcing. This calculation is an effective estimate of drought stress on soils and plants, which recent studies indicate could serve as an effective control on vegetation cover types in the Bay Area (Will Cornwell, Ackerly Lab, Department of Integrative Biology, University of California, Berkeley, written commun., 2012). In a Mediterranean climate, CWD can also be thought of as a surrogate for water demand from irrigation needs, and it quantifies the supplemental amount of water needed to maintain current vegetation types, whether natural cover or agricultural crops.

Calculations of CWD incorporate changes in soil moisture storage to estimate the AET. As a result, deep soils provide storage of winter precipitation and maintain lower deficits during the summer dry season, whereas shallow soils are limited in their storage capacity, so excess winter precipitation is lost to runoff, which results in greater annual deficits. The historic average annual CWD (1971-2000) is shown for the Bay Area in figure 10A, where low CWDs are apparent along the coast, particularly in the northern coastal regions, in contrast to greater deficits in the eastern basins along the edge of the Central Valley. Soils in excess of about 3 meters in channels in the Russian River Valley have lower deficits, and the shallow soils in the south Bay Area have high deficits similar to the drier Central Valley. Percent change in CWD between 1971-2000 and 2071-2100 under the A2 scenario (fig. 10) illustrates the effect of higher precipitation projected by the PCM model, yet nearly all locations show increases in CWD. There are some very small areas where soils that are more than 5-m deep do not limit storage when there is excess precipitation, and increases in CWD are limited to about 2-5 percent. These same locations, however, have large increases in CWD under the GFDL-A2 scenario (fig. 10B). Smaller changes in the CWD (fig. 10B) indicate the ability of some locations to withstand change in their hydrologic response to future climate changes. This resilience to climate change results from a combination of topographic features and aspect, soils, and geology that, when overlain by the larger scale climate, illustrates a range of variability that can be used to prioritize responses and potential management approaches.

In order to evaluate the effects of future climate changes on CWD in terms of potential effects on specific plant species, the value of average CWD (1971-2000) for every grid cell currently mapped as redwood forest (fig. 11A) in the Bay Area was determined (Bay Area Open Space Council, 2011). These values are represented by a cumulative probability plot (fig. 11B) that describes a bioclimatic distribution that represents the range of environmental conditions under which redwoods currently live. This process was repeated for the currently mapped locations for future 30-year periods projected by GFDL-A2. The A2 scenario was used because it most closely represents the currently measured greenhouse gas emissions (fig. 3). The current locations of redwood forest showed increases in CWD in the future: by 2040, at the 50 percent probability level, the CWD increases by about 4 percent; by 2070, the CWD increases by about 14 percent; and by 2100 , the CWD increases by about 23 percent. By the end of the century, 30 percent of the cells show increases in CWD values that exceed those of current redwood forest locations, thus describing a novel climate in this region for this species. This bioclimatic distribution approach can be applied to specific locations to assess how potential changes in CWD could affect vegetation distribution in the future. Examples for the case study locations in the Russian River Valley and Santa Cruz Mountains are presented in the following sections. 

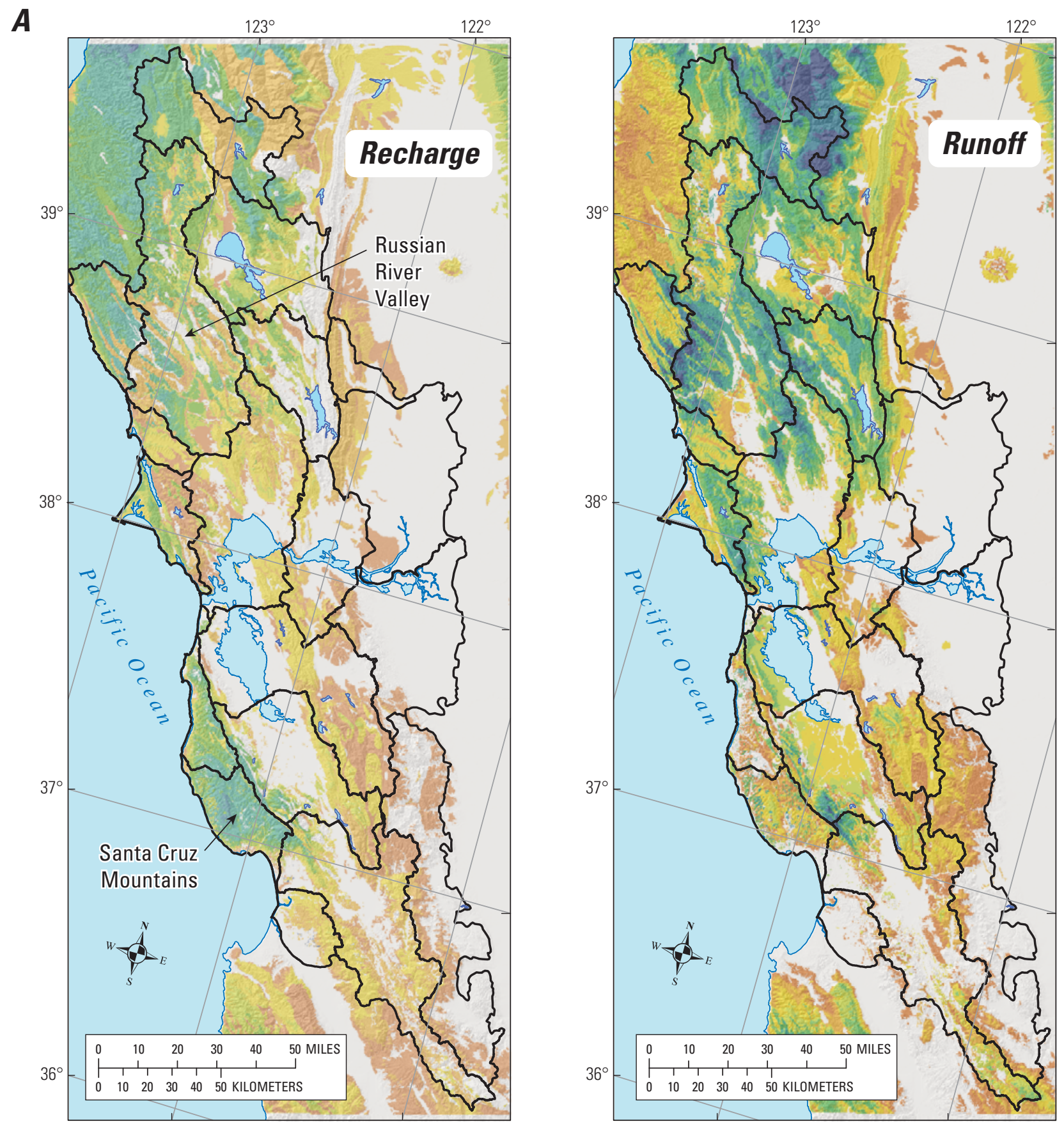

\section{EXPLANATION}

RECHARGE OR RUNOFF, 1971 TO 2000,

IN MILLIMETERS PER YEAR

Iร San Francisco Bay
area basins

\begin{tabular}{|c|c|}
\hline 0 to 20 & 300 to 400 \\
\hline 20 to 50 & 400 to 500 \\
\hline 50 to 100 & 500 to 750 \\
\hline 100 to 200 & 750 to 1,000 \\
\hline 200 to 300 & 1,000 to 1,800 \\
\hline
\end{tabular}

Figure 9. The spatial distribution of runoff and recharge for basins in the San Francisco Bay Area, California, $(A)$ during 1971-2000 and $(B)$ its change between 1970-2000 and 2070-2100 for GFDL-A2 and PCM-A2 projections. 
B

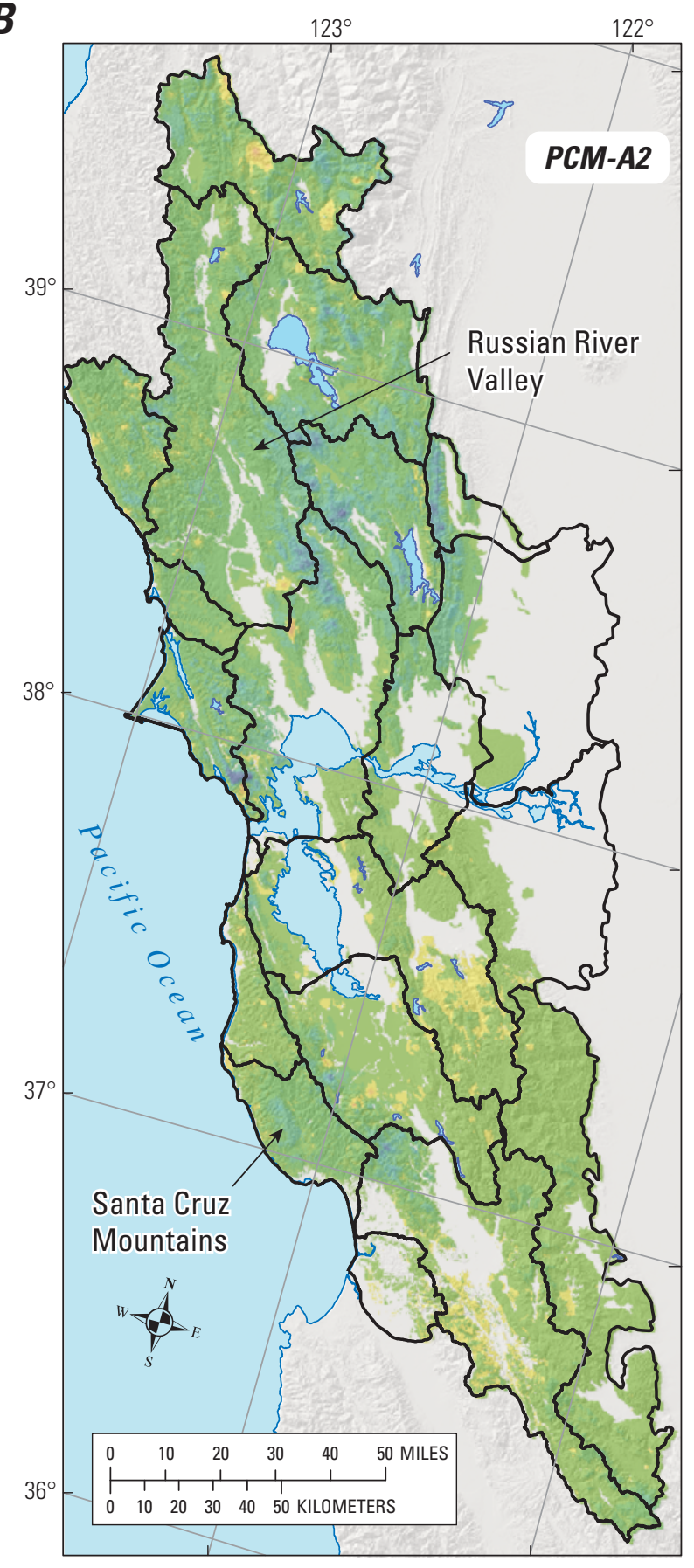

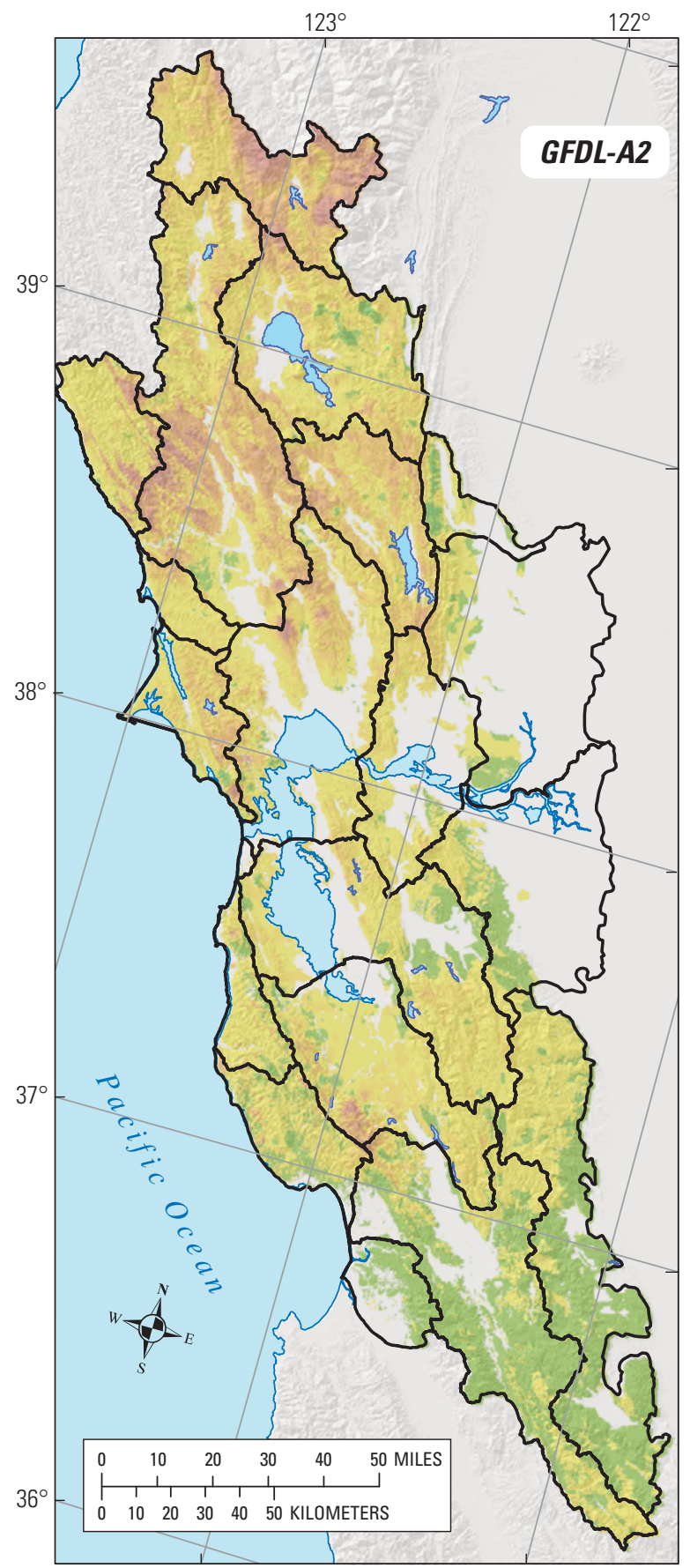

\section{EXPLANATION}

CHANGE IN RUNOFF, IN MILLIMETERS PER YEAR

\begin{tabular}{|c|c|c|c|c|}
\hline 300 to 400 & $\square$ & 50 to 100 & $\square$ & -100 to -150 \\
\hline 250 to 300 & 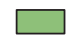 & 0.1 to 50 & & -150 to -200 \\
\hline 200 to 250 & 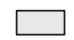 & -0.1 to 0.1 & & -200 to -250 \\
\hline 150 to 200 & ᄃ & -0.1 to -50 & & -250 to -300 \\
\hline 100 to 150 & & -50 to -100 & & \\
\hline
\end{tabular}

Figure 9.-Continued 
$\boldsymbol{B}$

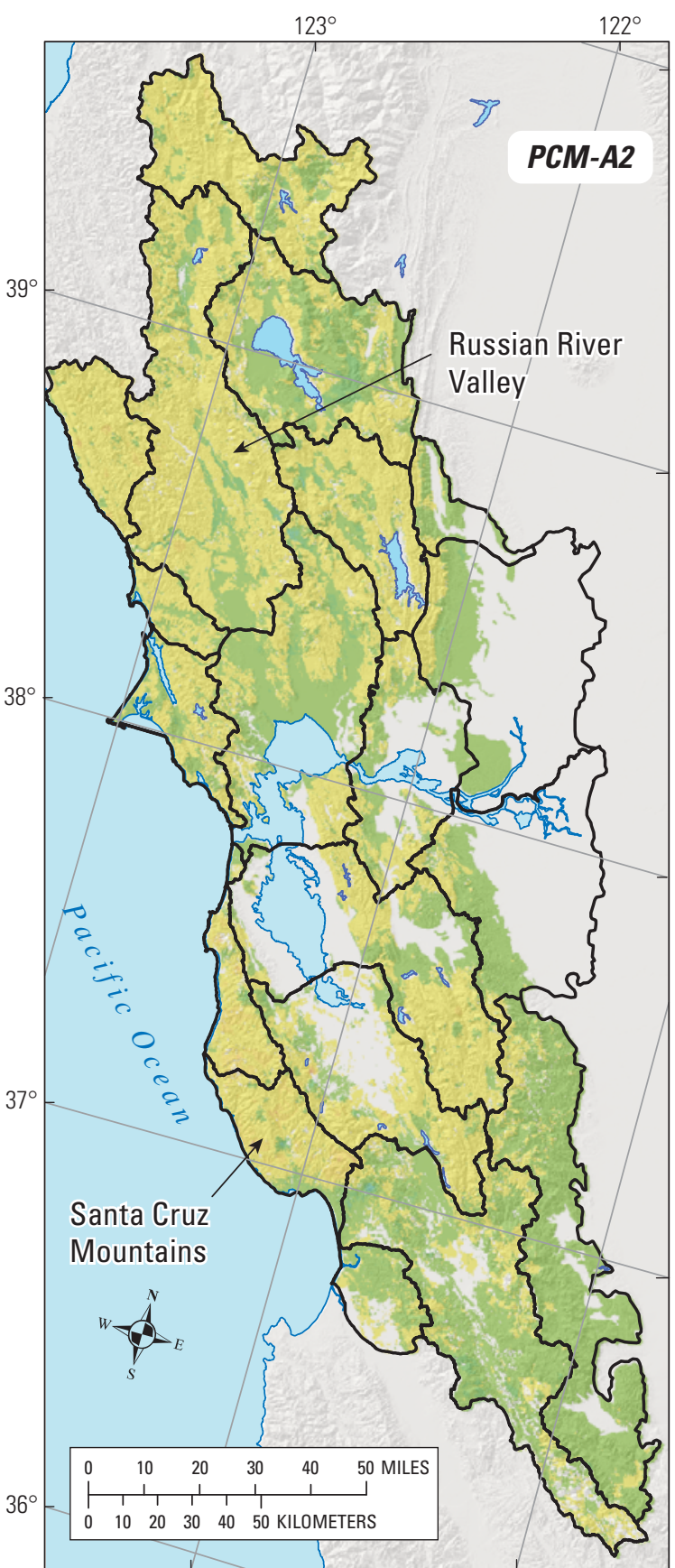

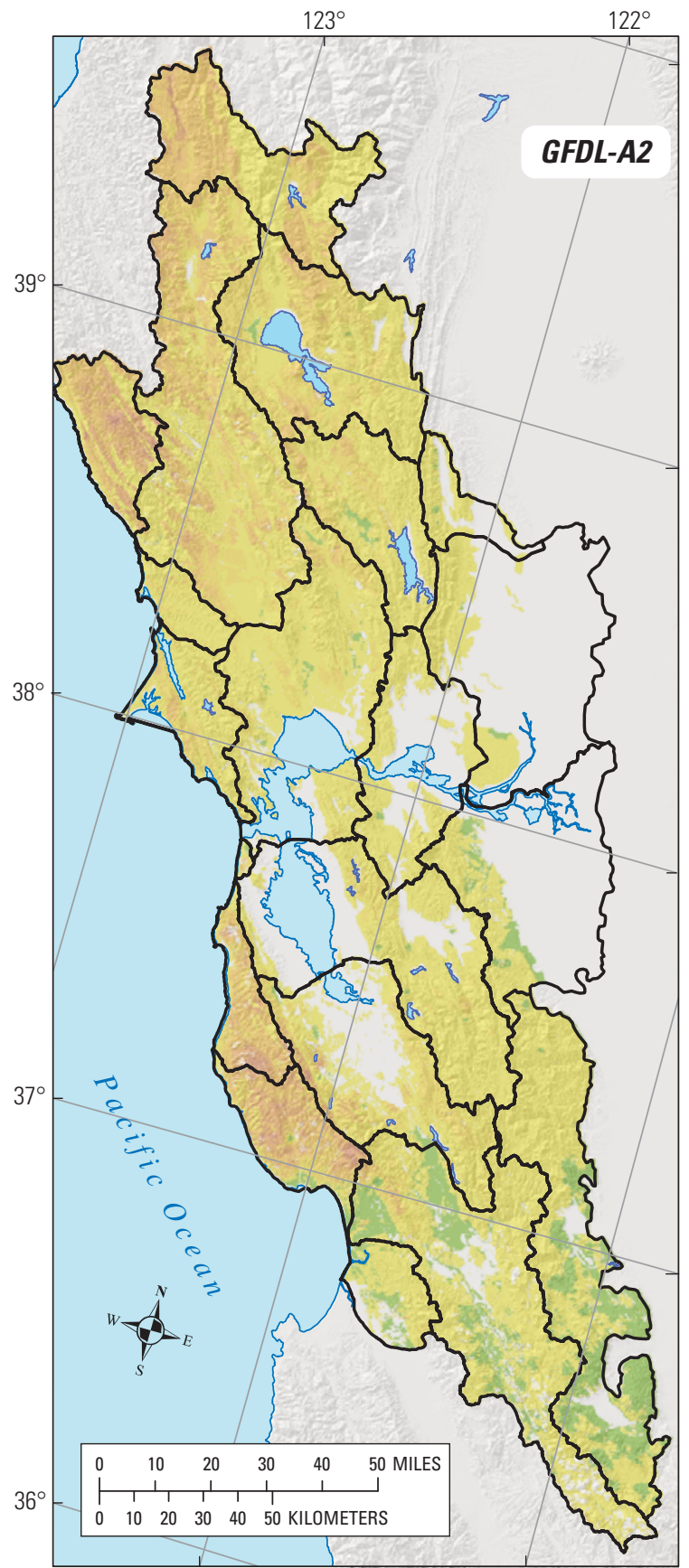

EXPLANATION

CHANGE IN RECHARGE, IN MILLIMETERS PER YEAR

300 to $400 \quad \square \quad 50$ to $100 \square-100$ to -150

250 to $300 \quad \square \quad 0.1$ to $50 \quad \square \quad-150$ to -200

200 to $250 \square \quad \square \quad 0.1$ to $-0.1 \square-200$ to -250

150 to $200 \square-0.1$ to $-50 \quad \square \quad-250$ to -300

100 to $150 \square-50$ to -100

Figure 9.-Continued 
$\boldsymbol{A}$

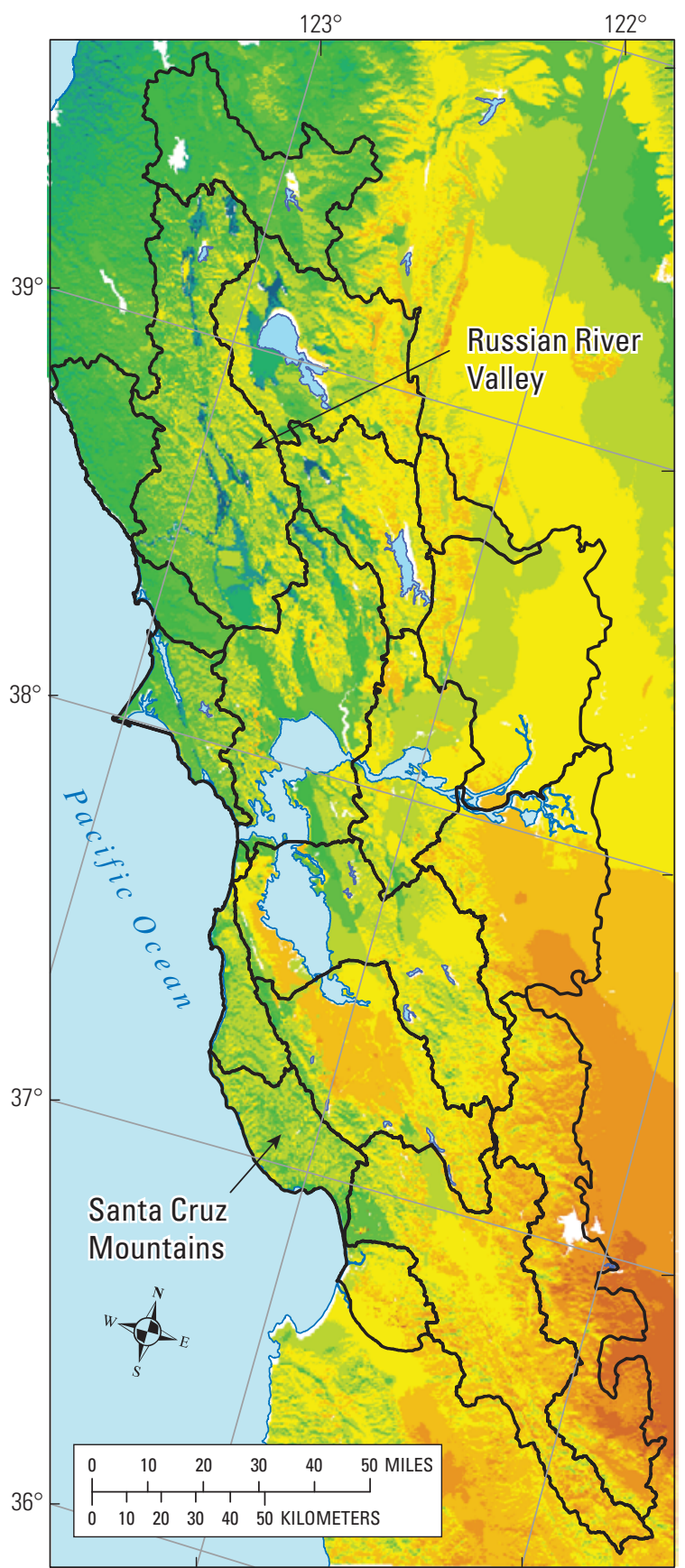

\section{EXPLANATION}

CLIMATIC WATER DEFICIT, 1971 to 2000 , IN MILLIMETERS PER YEAR

$>200$ to $300 \square>800$ to 900 $>300$ to 400 $>400$ to 500 $>500$ to 600 $>600$ to 700 $>700$ to 800 $>900$ to 1,000 $>1,000$ to 1,100 $>1,100$ to 1,200 $>1,200$ to 1,300 $>$ is greater than

Figure 10. Spatial distribution of climatic water deficit for basins in the San Francisco Bay Area, California, for $(A)$ the 1971-2000 average and $(B)$ its percent change between 1970-2000 and 2070-2100 projected by GFDL-A2 and PCM-A2. 
B

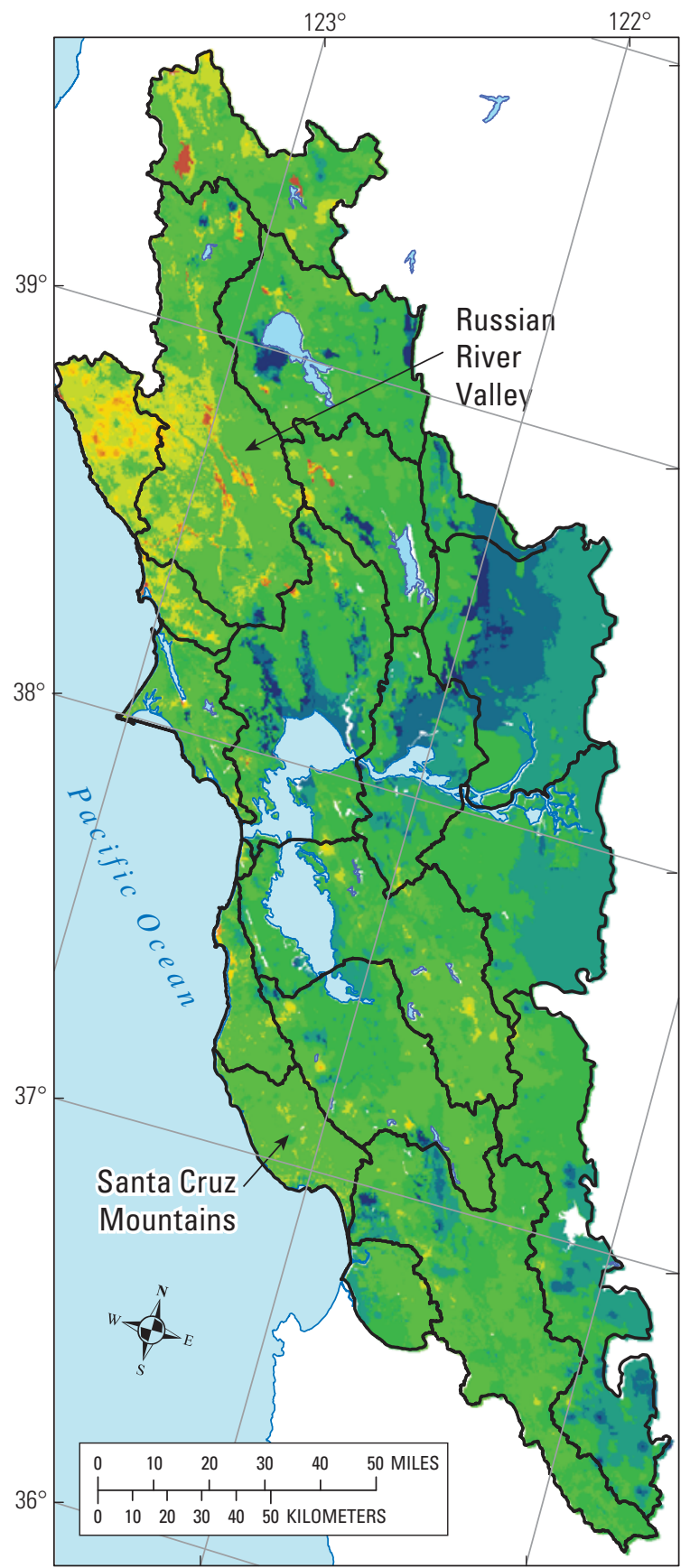

PCM-A2

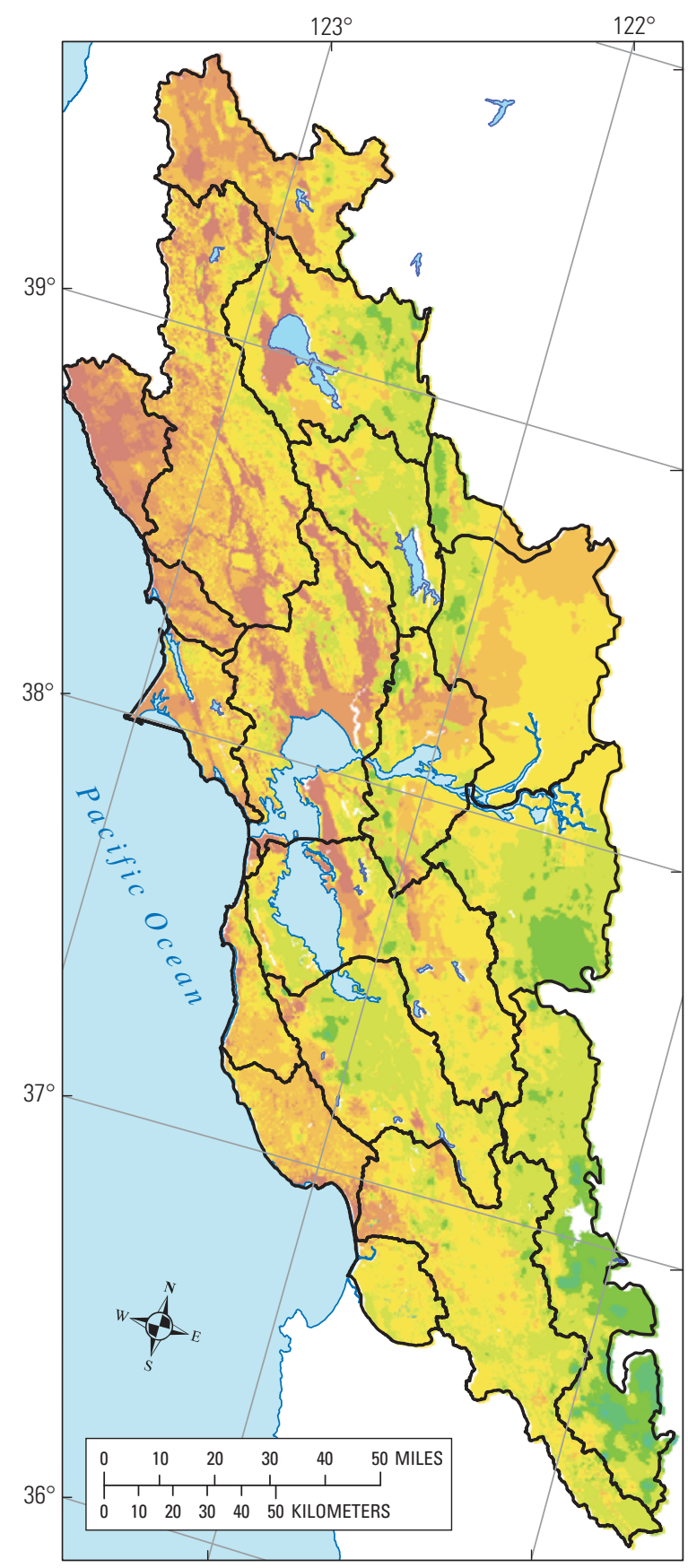

GFDL-A2

\section{EXPLANATION}

PERCENT CHANGE IN CLIMATIC WATER DEFICIT

\begin{tabular}{|r|r}
-4 to -8 & 12 to 16 \\
0 to -4 & 16 to 20 \\
4 to 0 & 20 to 24 \\
4 to 8 & 24 to 30 \\
\hline 8 to 12 & $-\square 0$ to 40
\end{tabular}

Figure 10.-Continued 


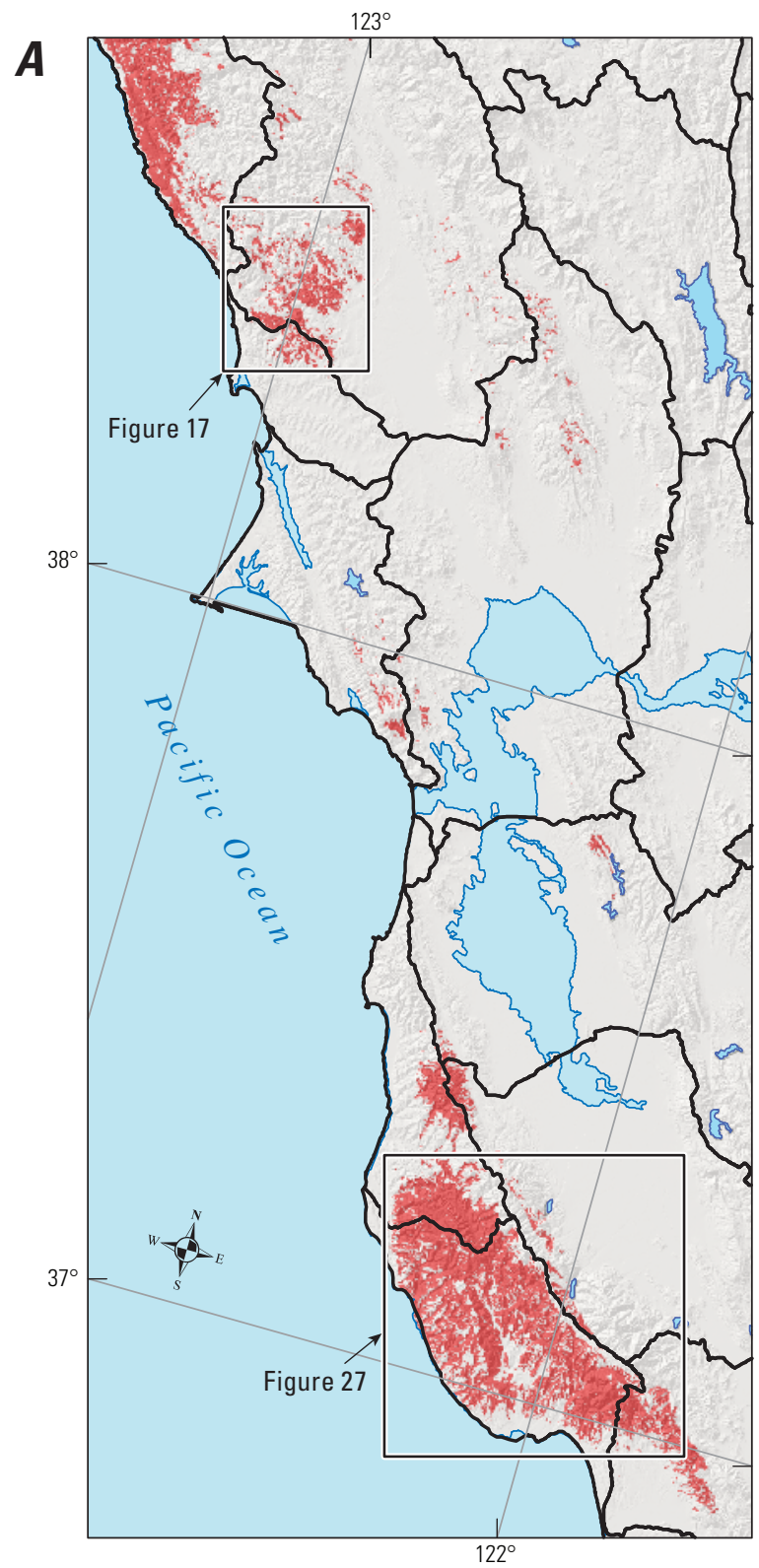

\section{EXPLANATION}

$\square$ Area of Redwood forest

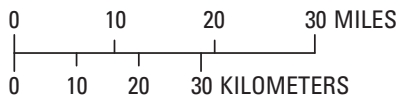

$\boldsymbol{B}$

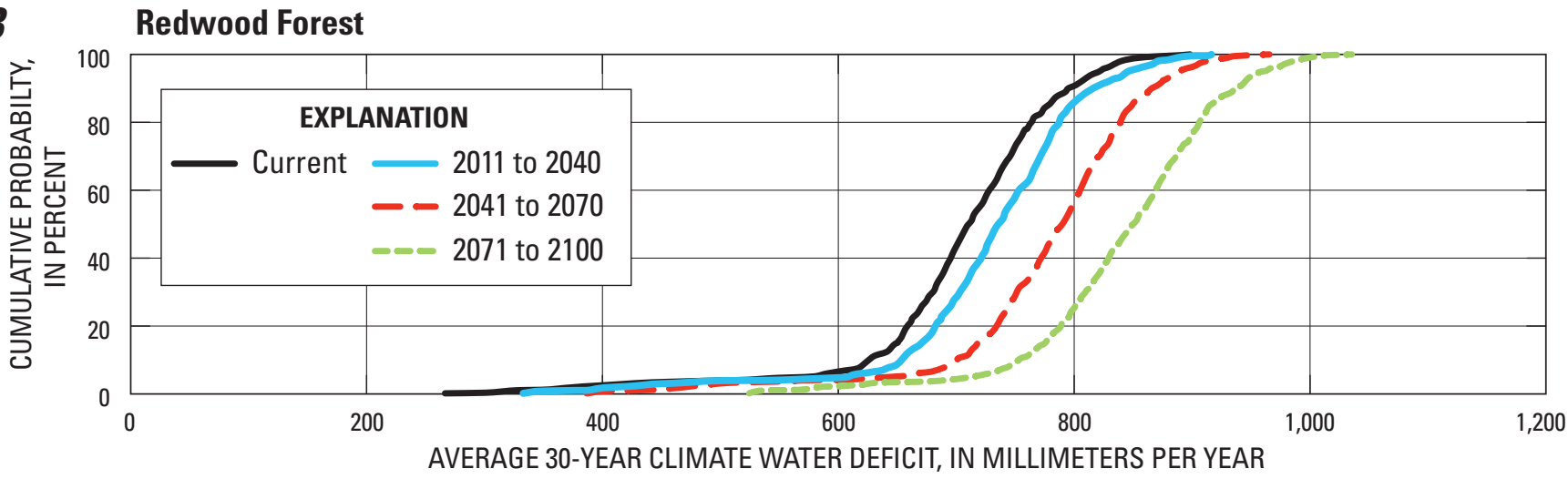

Figure 11. Areas of mapped redwood forest in the San Francisco Bay Area, California, basins $(A)$ currently and $(B)$ bioclimatic distribution of climatic water deficit in areas of redwood forest for current and future 30-year periods by using the GFDL-A2 projection. 


\section{Russian River Valley}

\section{Model Calibration}

The BCM model for the Russian River Valley was specifically calibrated to 17 streamgages (fig. 12; table 1 ) to provide an understanding of current and future unimpaired flow conditions for nine flow nodes (fig. 12) that correspond to unimpaired flow inputs for the Sonoma County Water Agency water management model. The basin receives imported water from the Eel River that flows from Lake Pillsbury. Changes in future water availability from this basin, therefore, have the potential to affect the Russian River as well. The two primary sources of stored water in the basin are Lake Mendocino in the East Fork Russian River basin and Lake Sonoma in the Dry Creek basin. Other important subbasins are the headwaters of the Russian River (basin above Map Identification 2) and the Mark West Creek basin that contains the large urbanized cities of Santa Rosa, Cotati, and Rohnert Park.

Generally, calibration results were good and values for monthly and yearly regression coefficients, $\mathrm{r}^{2}$, averaged 0.84 and 0.90 , respectively, and Nash-Sutcliffe efficiency values, E, averaged 0.72 (table 1). Figure 13 shows calibration results for two subbasins on the basis of measured flow at the gages: Maacama Creek (USGS gage ID 114763900), which had an E value of 0.83, and Feliz Creek (USGS gage ID 11462700), which had a relatively poor E value of 0.52 . Feliz Creek had a much shorter period of record, and several peaks were not accurately simulated, which likely accounted for the lower E value. Aside from short records, it is difficult to assess the reason for lack of fit in several subbasins, particularly when the peaks are matched in some years but not in others. It could be that impairments, such as small diversions or impoundments for local agriculture, cannot be accounted for by using the BCM, which results in variation in goodness-offit among the subbasins. Two gages on the western border of the Russian River Valley near Feliz Creek, Dry Creek near Yorkville and Warm Springs near Asti, also had relatively poor E values of 0.47 and 0.44 , respectively, and peak yearly discharge values were consistently underestimated, which indicates a poor estimate of bedrock permeability in that region. Low flows, however, matched measured streamflows for these subbasins.

Several factors complicate the calibration of the BCM to measured streamgage data, and the subsequent interpretation of the calibration results is subject to several caveats. Because the model does not route streamflow, there are subsequent uncertainties associated with the monthly time step of the BCM. The discharge in large basins, or basins with long groundwater flow paths that result in long travel times, is less likely to match the measured timing of streamflow. Thus, the yearly regression coefficient, $\mathrm{r}^{2}$, is a more robust measure compared to the monthly $\mathrm{r}^{2}$. As noted previously, whether a streamgage represents unimpaired conditions in a subbasin and the nature of impairment are the most uncertain factors in the assessment of calibration statistics. Another consideration, however, is whether there are subsurface interbasin flows, such as in Big Sulphur Creek (Map identification 10; table 1), which receives naturally upwelling groundwater from areas outside of the Russian Basin to the east. The BCM underestimated flows to the gages, and it was necessary to multiply the groundwater fraction of the total basin discharge by a factor of three to optimize the calibration, which indicates sources of groundwater from outside the basin.

\section{Changes in Water Availability}

The response of hydrologic variables, including runoff, recharge, and streamflow, is highly sensitive to variation in precipitation. This is shown over time and between GCMs. The range and variability of estimated precipitation regimes indicated by the two models are evident in figure 8. Changes in spatially distributed runoff and recharge shown in figure 9 for the Russian River Valley during the 21st century range from increases of approximately $250 \mathrm{~mm} / \mathrm{yr}$ to decreases of $250 \mathrm{~mm} / \mathrm{yr}$, which are reflected in estimates of future basin discharge. Cumulative frequency calculations of basin discharge are shown in figure 14 for two streams for historical and future conditions. For any given frequency, basin discharge is lower for both streams in the GFDL-A2 projection, and high flows are not projected to exceed those of the historical period. On the other hand, the PCM-A2 projects discharge similar to or slightly higher than historical conditions for all but the highest flows, which are projected to far exceed historical flows for both streams by the end of the 21st century.

Low flows and potential droughts are shown in figure 15 for 90 historical years and 90 future years in two streams by using a 3-yr running average. Water managers generally declare drought conditions after 3 successive years of dry conditions, and droughts in the early-1930's, late 1940's, mid-1970's, and late 1980's are evident in these figures. In figure 15, this is represented by an arbitrary dotted line indicating a lower discharge threshold potentially characterizing drought conditions for these two streams. In the future, discharges fall below this line somewhat more frequently than historically, particularly for the last 30 years of the century under the GFDL-A2 projection, when there is a multi-decadal drought. 


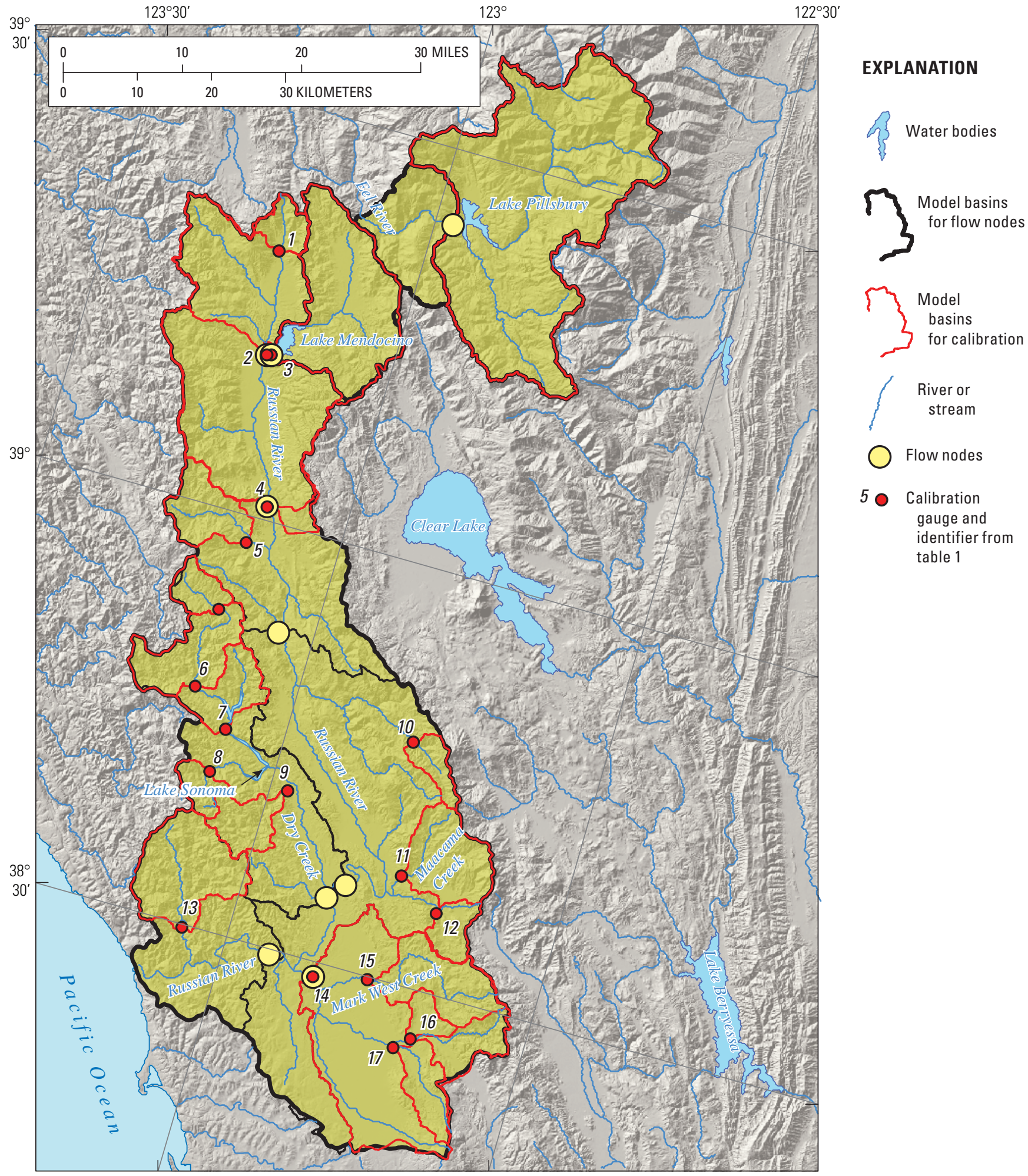

Figure 12. Location of calibration basins, streamflow gages, and model nodes used by the Sonoma County Water Agency in the Russian River Valley, California. 


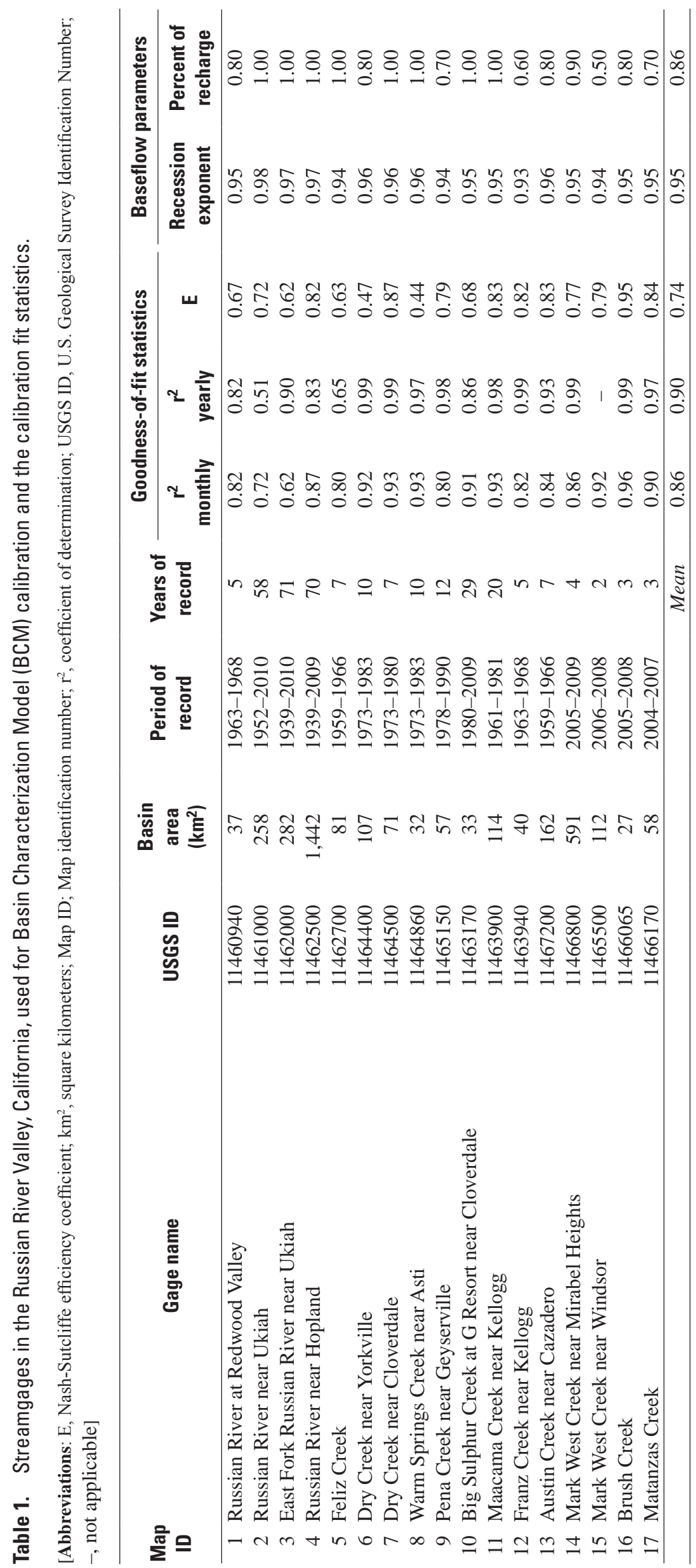



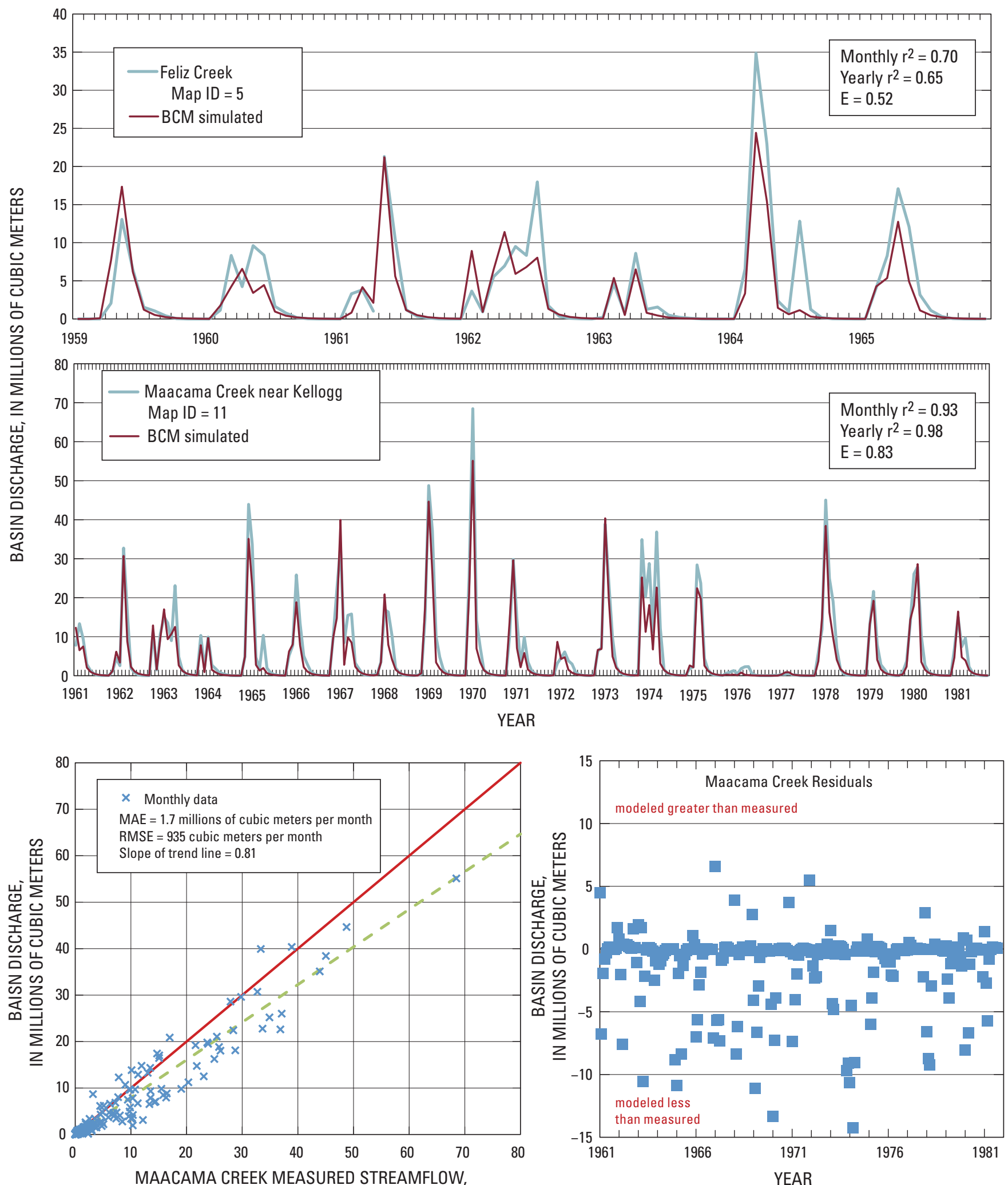

Figure 13. Comparison of measured basin discharge to discharge simulated using the Basin Characterization Model (BCM) for streamgages at Feliz Creek and Maacama Creek near Kellogg in the Russian Basin, California, including goodness-of-fit analyses of Nash-Surcliffe Efficiency error (E) and coefficient of determination $\left(r^{2}\right)$. Mean absolute error (MAE), root mean squared error (RMSE), and regression residuals were also evaluated for Maacama Creek. 

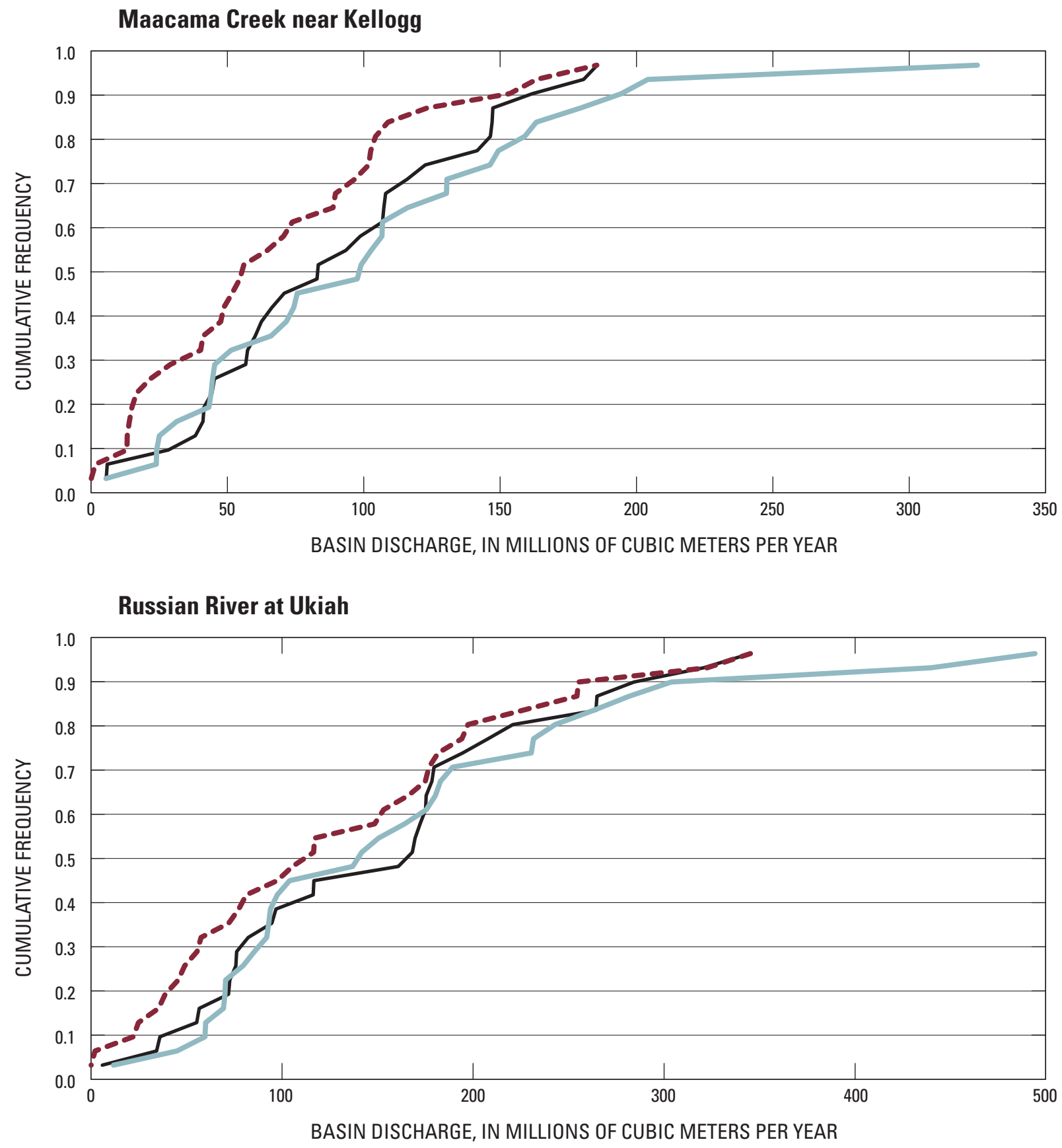

\section{EXPLANATION}

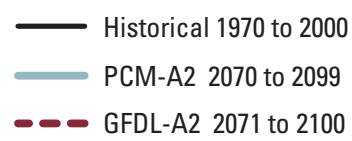

Figure 14. Cumulative frequency of basin discharge for two subbasins in the Russian Basin, California, for historic (1971-2000) and projected (2071-2100) 30-year periods from GFDL-A2 and PCM-A2. 


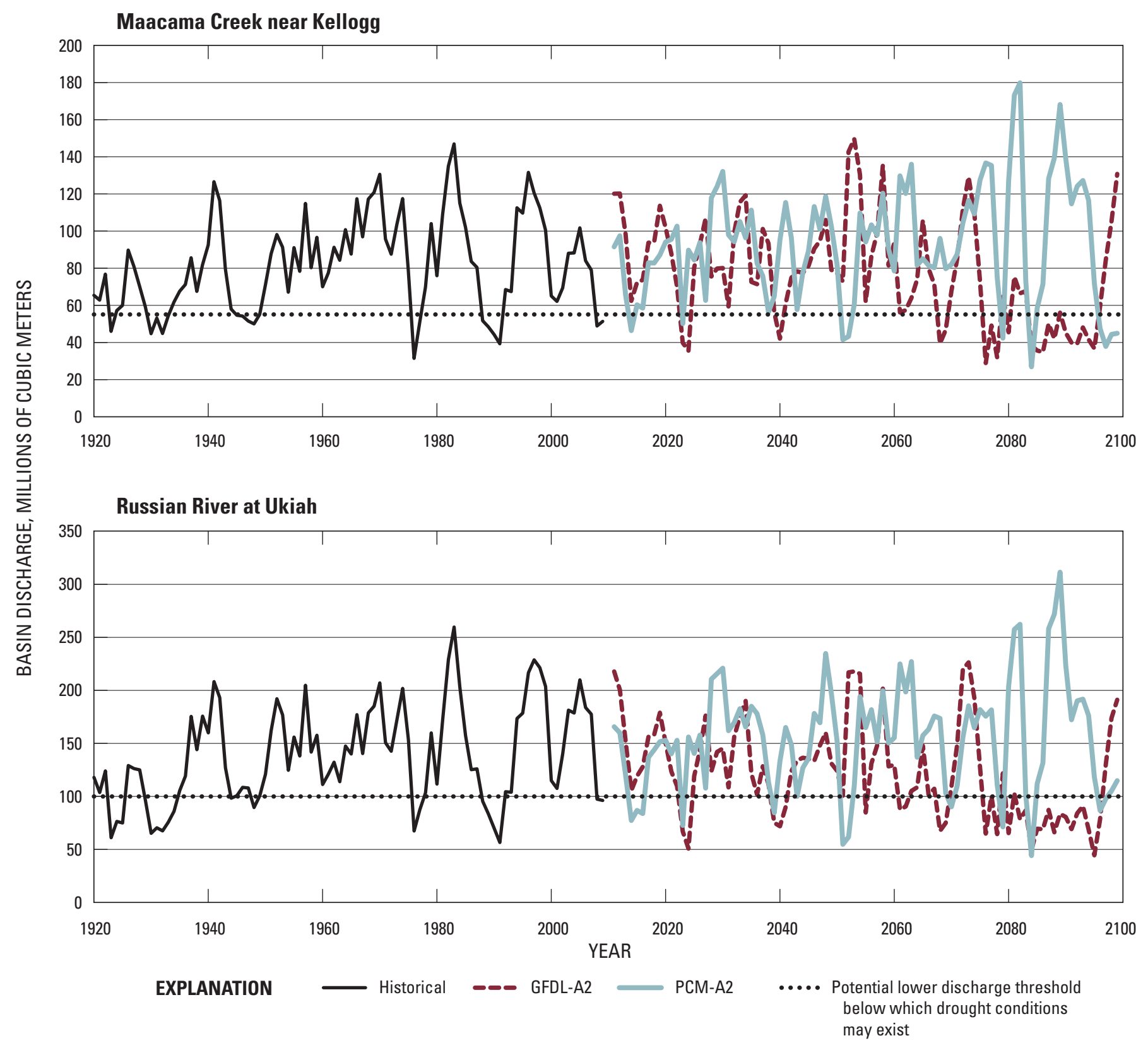

Figure 15. Historic measurements and two projected discharge estimates in 3-year running averages for two subbasins in the Russian Basin, California, 1920-2100.

The seasonal timing of the water-balance components precipitation, potential evapotranspiration, recharge, and runoff are shown in figure 16 by monthly average $30-\mathrm{yr}$ plots of historical conditions at the end of the 20th century and projected conditions for the end of the 21st century. Averaged over the whole Russian River Basin, precipitation appears to shift from peaking in January to peaking in February in the future, and both projections show less fall (October-November) and spring (April-May) precipitation. Potential evapotranspiration shows no shifts in timing, and both projections indicate higher potential evapotranspiration as a result of higher air temperatures, particularly in the summer. Recharge and runoff, which are strongly influenced by precipitation, also shift peaks from January to February and show fall precipitation at about half of historical values. In the GFDL-A2 projection, spring recharge also is lower than historical, but in the PCM-A2 projection, recharge is greater than historical values during February and March but lower again during April. Both projections indicate a shorter wet season by the end of the 21st century. 


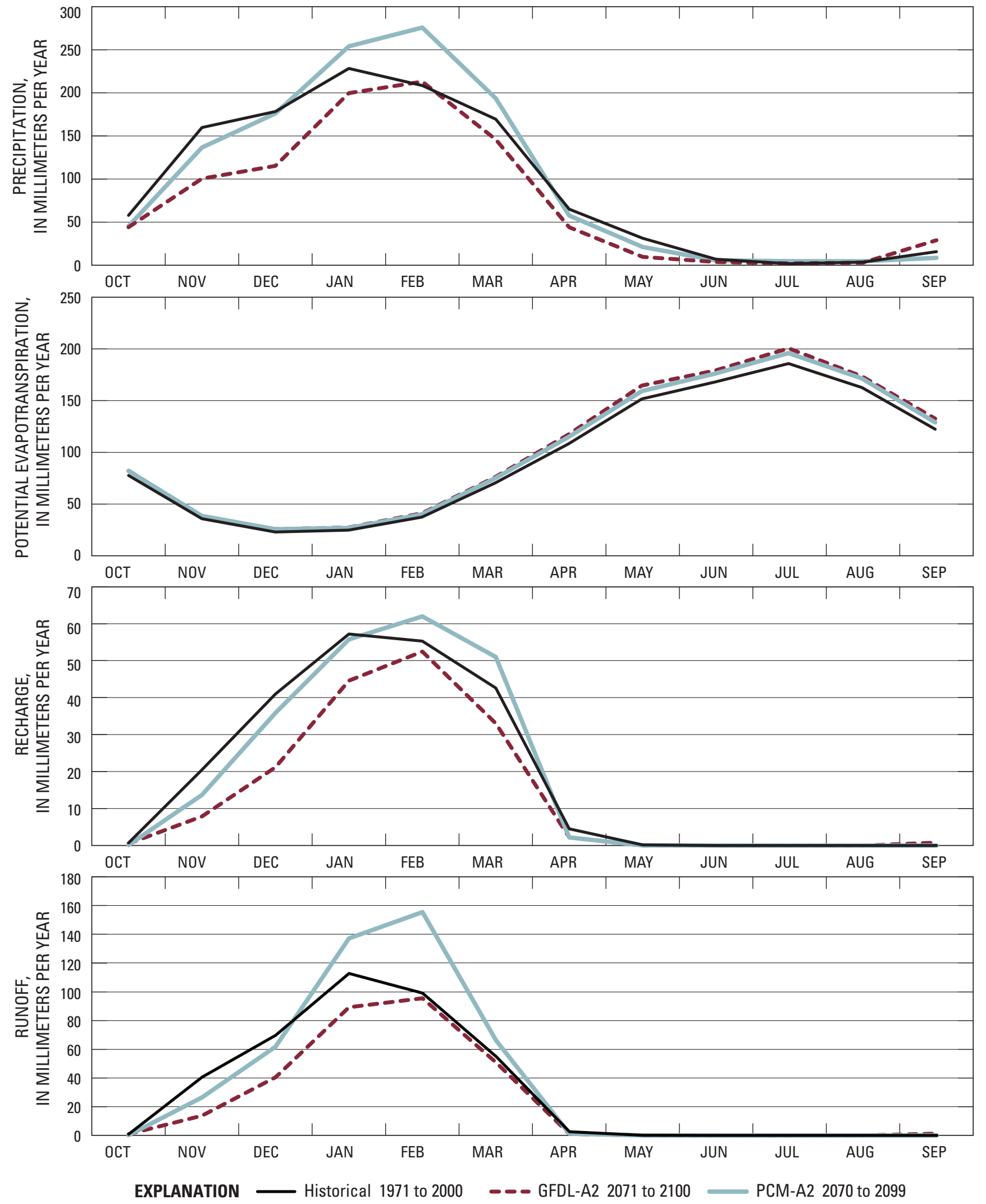

Figure 16. Historical measurements and two estimated future projections of precipitation, potential evapotranspiration, recharge, and runoff shown by mean 30-year monthly averages for the Russian River Valley, California. 
Historical values for 1971-2000 and quantitative estimates of projected climate and hydrology for major water supply basins in the Russian River Valley for all four projections are provided as mean values for 30 -yr periods of all components of the climate and water balance in appendix 1. All drainages discharging to Mark West Creek and Dry Creek, the headwaters of the Russian River, the west and east forks of the Russian River, and locations draining into the Lake Pillsbury basin are included.

\section{Landscape Effects}

Regardless of the direction of the precipitation or water supply in the future for the Russian River Valley, the dominant feature of climate change is the increase in air temperature, which is reflected in the climatic water deficit (CWD). Changes in CWD are shown in figure 10 for both projections, where slight reductions in deficit are apparent for the wetter PCM model, but most locations experience an increase in CWD by the end of the century. The effects of change in CWD on the area covered by redwood forest, the signature species in much of the Russian River Valley, can provide an excellent example of potential climate change effects on the landscape.

First, the range of CWD under which the redwoods currently live, based on the bioclimatic distribution determined for 1971-2000 (fig. 11), was defined as suitable habitat conditions. All species' ranges have extreme edges of suitability within their distribution, where conditions are adequate although not optimal, and we defined the upper and lower 10 percent of the distribution as the extremes. Excluding this upper and lower 10 percent, all locations in the region surrounding the lower Russian River channel that have an average 30-year CWD between $640-800 \mathrm{~mm} /$ yr for 1971-2000 are shown in figure 17A. Suitable redwood habitats include south facing slopes and most ridge tops somewhat inland of the Pacific Ocean and exclude many channel bottoms. The same view at the end of the 21st century (fig. 17B) shows the suitable habitat moved to the north facing slopes and nearer the coast and includes more channel bottoms. When the current locations of redwood forest are overlain on the current (1971-2000) distribution of suitable habitat (fig. 18), there is sparse redwood cover in the upper end of the distribution, where there is the highest water deficit, but the low end of the distribution is somewhat better represented by several pockets where CWD is quite low. By the end of the 21st century (fig. 19), the middle of the suitable CWD distribution moved to areas that were previously characterized as low CWD, and locations in the upper 10 percent of the CWD distribution were no longer suitable habitat. Also, a much greater proportion of the area was now in the upper 10 percent of suitable CWD. Interestingly, there were areas of redwood forest cover where CWD did not change in the future so that habitat continued to overlay the historical distribution.
These were located along the Russian River channel, where deeper soils and lower energy loading provide resilience to change. This example of the changing location of redwood forest habitat provides information about the locations of the most vulnerable of the current redwood forest habitat, and where management can focus the most advantageous use of resources to preserve future redwood forest.

\section{Santa Cruz Mountains}

\section{Model Calibration}

The calibration of the BCM for the Santa Cruz Mountains required further refinement of the geologic map to include the distinctly groundwater-dominated Santa Margarita sandstone in the center of the Santa Cruz basin (fig. 4). As shown in figure 9, the drainage basin of the Santa Cruz Mountains is susceptible to changes in recharge, regardless of model projection, in comparison to most drainage basins in the Bay Area. Calibration of the BCM for this area was complicated by the urbanization surrounding or upstream of many of the streamgages (fig. 20). Of the 17 gages to which the model was calibrated, 8 had some degree of urbanization or agriculture (fig. 20; table 2). This resulted in either reductions in measured flow due to withdrawals of groundwater, which is reflected in lower streamflow, or direct streamwater use, so that flows appeared overestimated by the BCM, or as urban runoff appearing as increases in peak flows, so that flows seemed underestimated by the BCM. Two subbasins, the highly urbanized Carbonera Creek in upper Branciforte Creek basin and Bean Creek just north of Carbonera Creek, only had peak flow gages and were not used in the model calibration. Two gages that had little to no known impairments, Zayante and West Branch Soquel Creeks, are shown in figure 21. Simulated and measured discharge for these two creeks compared favorably, as indicated by relatively high E values (table 2). Goodness-of-fit of simulated basin discharge to measured discharge is shown in table 2 for all gages, and has an average monthly $\mathrm{r}^{2}$ of 0.74 , yearly $\mathrm{r}^{2}$ of 0.84 , and average $\mathrm{E}$ values of 0.65 . Model calibration was optimized for low-flow periods that are dominated by baseflow. Poor fits $(\mathrm{E}=0.23)$ are shown for Boulder Creek, where simulated low flows matched measured low flows, but peaks were mostly underestimated, likely as a result of urban runoff.

\section{Water Availability}

Future projection analyses assume that current land uses are maintained constant, and therefore, changes in water availability are solely a function of changes in climate, and inaccuracies in calibration fits are, therefore, disregarded in the analysis. 


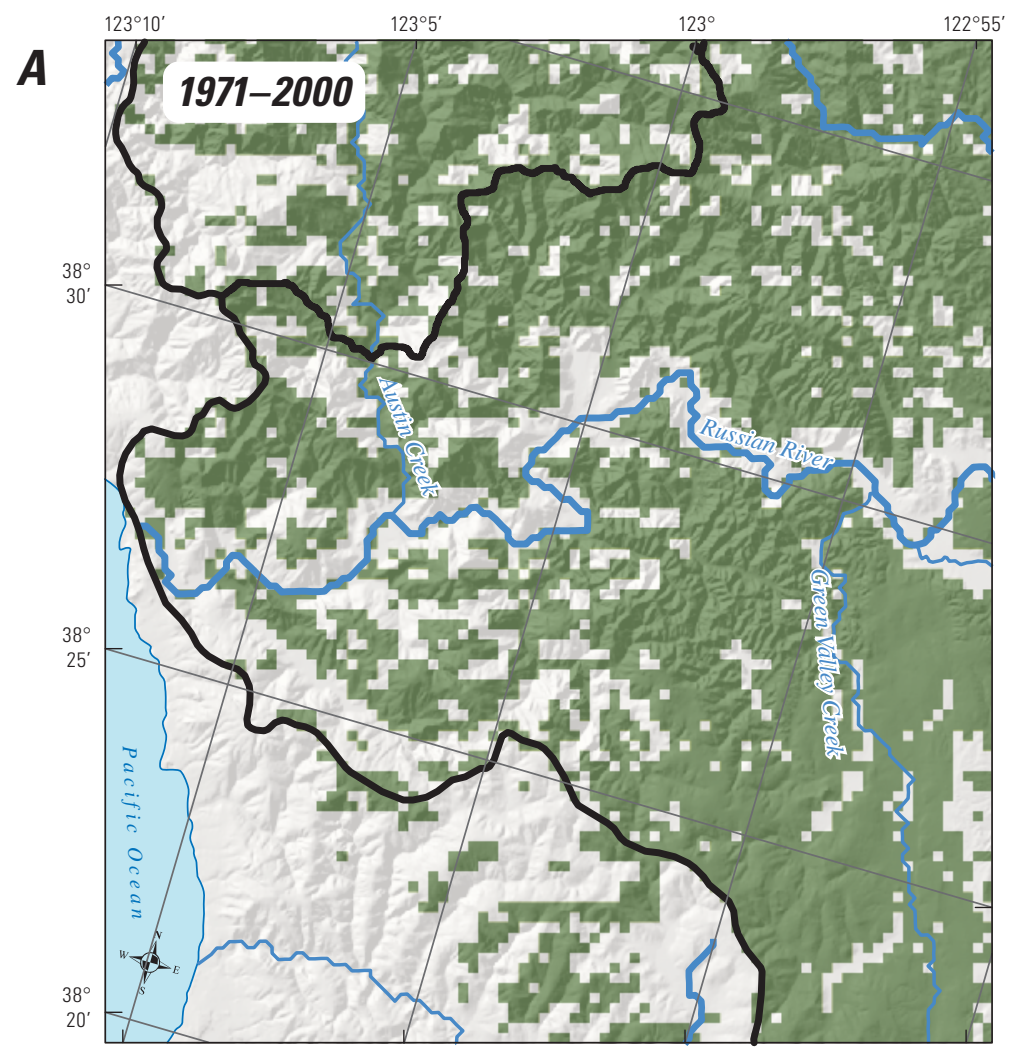

\section{EXPLANATION}

Suitable climatic water deficit
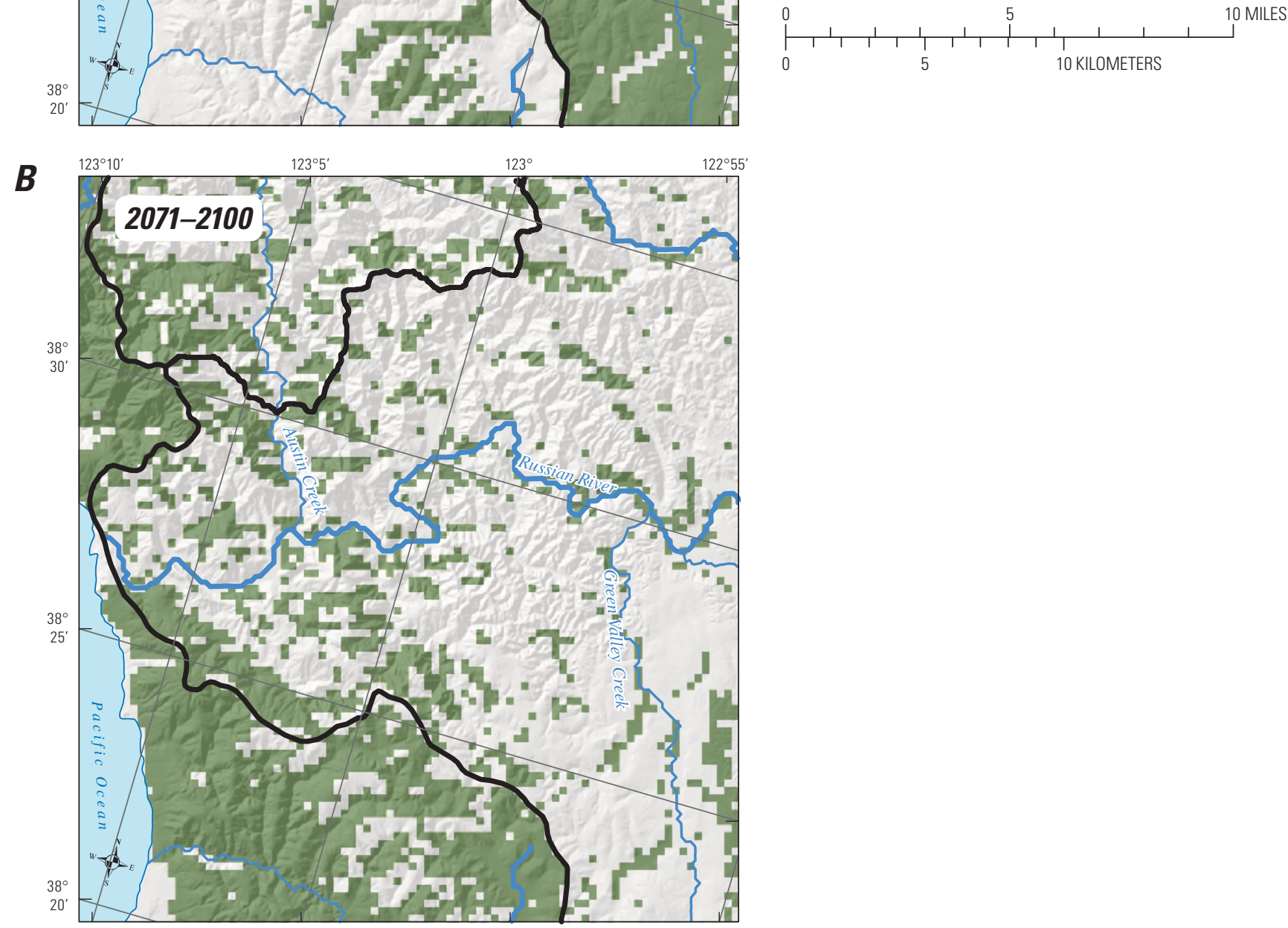

Figure 17. Range of suitable habitat for redwood forest based on climatic water deficit describing the bioclimatic distribution of $(A)$ a historical and $(B)$ a future period from the GFDL-A2 projection in the Russian River Valley, California. 


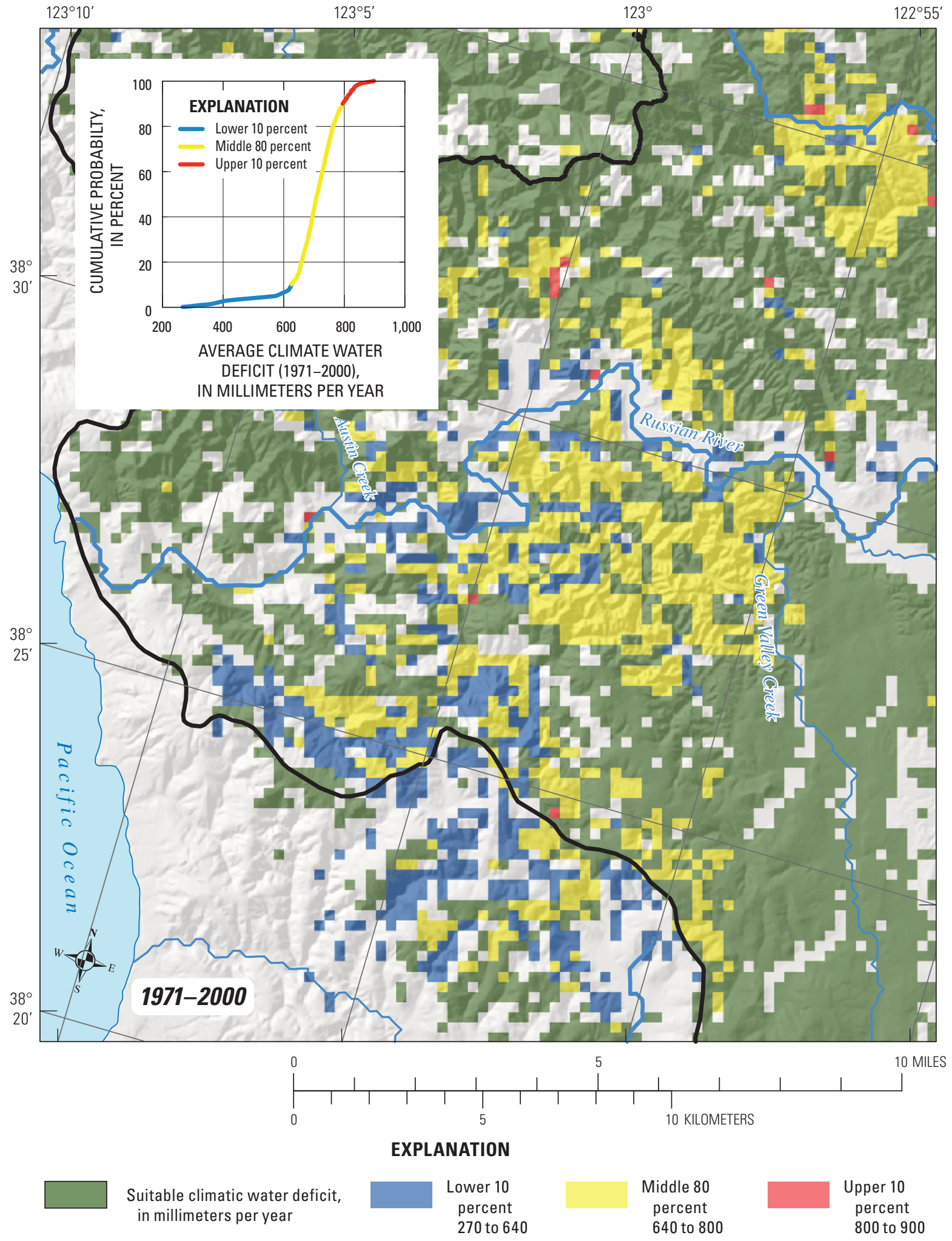

Figure 18. Average climatic water deficit of the current bioclimatic distribution for redwood forest in the Russian River Vally, California, showing the middle 80 percent of range and the upper and lower 10-percent tails. 


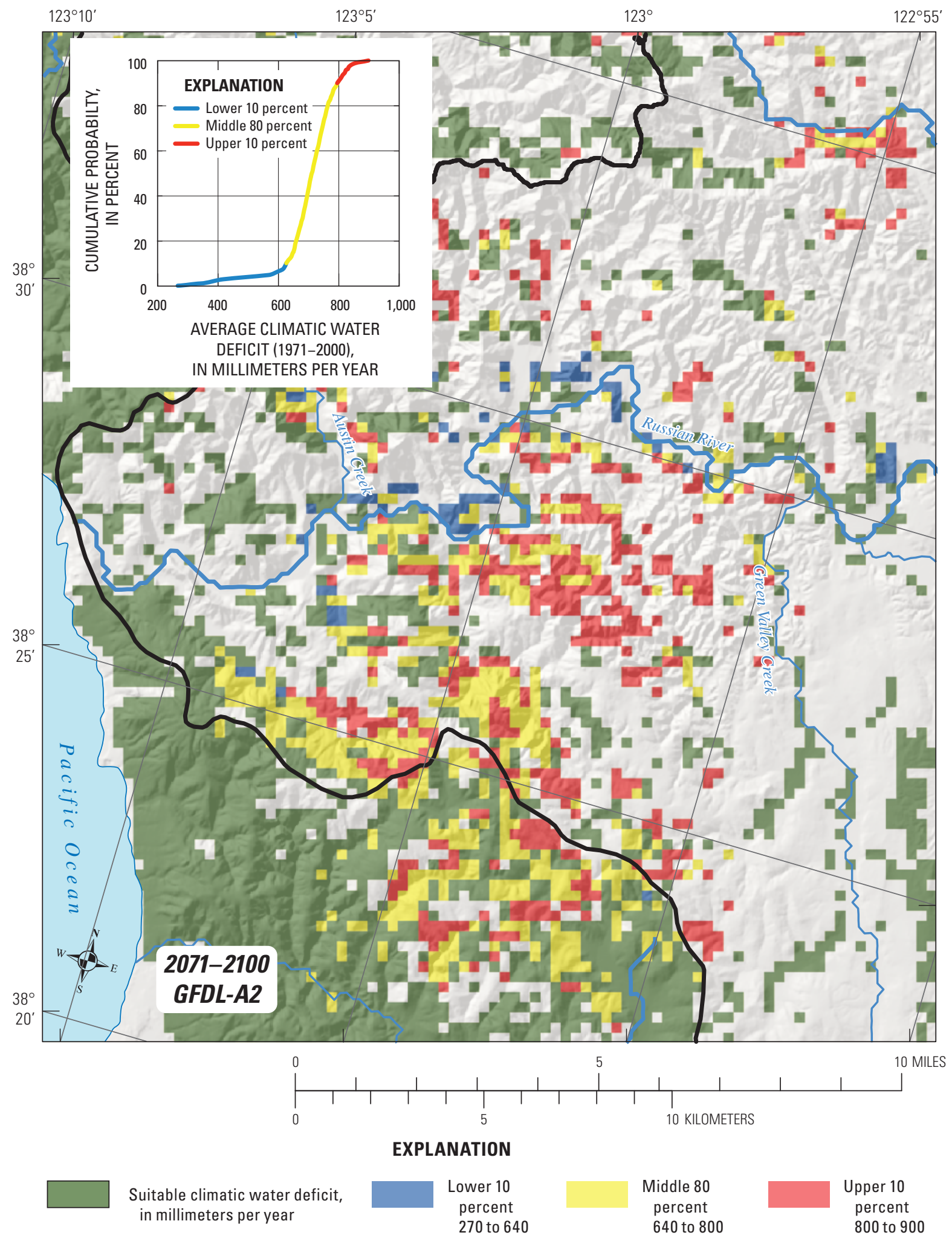

Figure 19. Average climatic water deficit projected for 2071-2100 for the current bioclimatic distribution of redwood forest in the Russian river Valley, California, showing the middle 80 percent of range and the upper and lower 10-percent tails. 


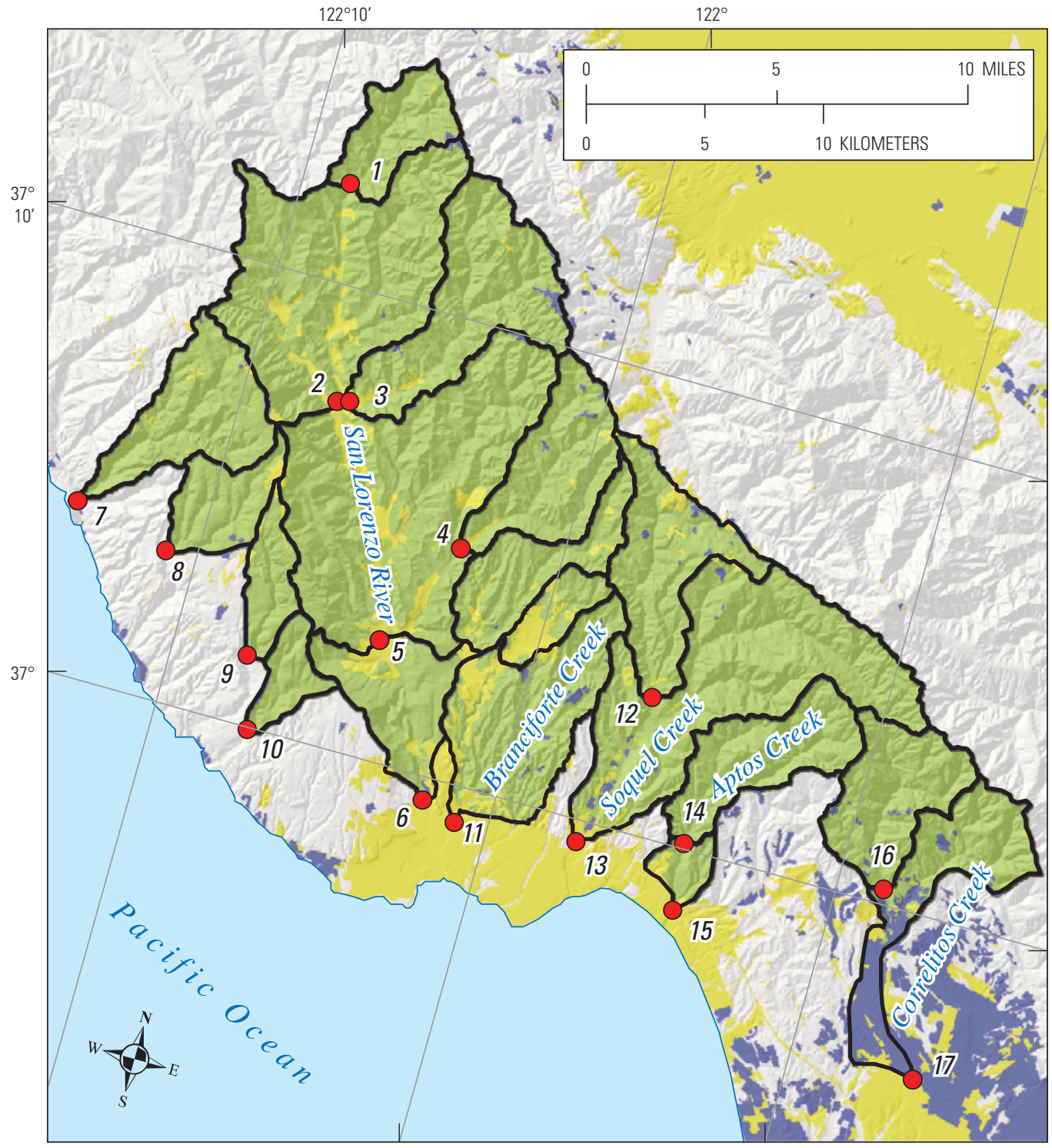

LAND USE

EXPLANATION
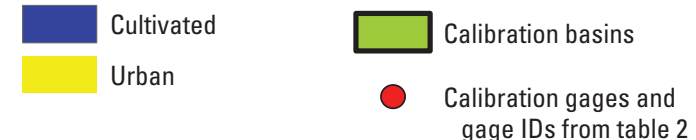

Figure 20. Calibration basins and streamgages, and urbanized and cultivated areas in the Santa Cruz Mountains, California.

Changes in streamflow as a function of climate change are illustrated as cumulative frequency curves of basin discharge for historical and future conditions for 30-year periods at the end of the 20th and 21st centuries (fig. 22). There is variation across the region, and the GFDL-A2 projection showed a greater effect on Zayante Creek than the San Lorenzo River, likely related to the larger amount of groundwater flow in the San Lorenzo River basin. In this projection, for both streams, all flows except the very highest are lower than historical flows, and the highest flows exceed historical flows by about $20-30$ percent. In the PCM-A2 projection, low flows are somewhat lower than historical flows, whereas the top 40 percent of flows are higher than historical. This reflects the increase in precipitation projected by the PCM model that is illustrated in figure 8 . Similar patterns are shown for all other calibration basins in appendix 2 . 


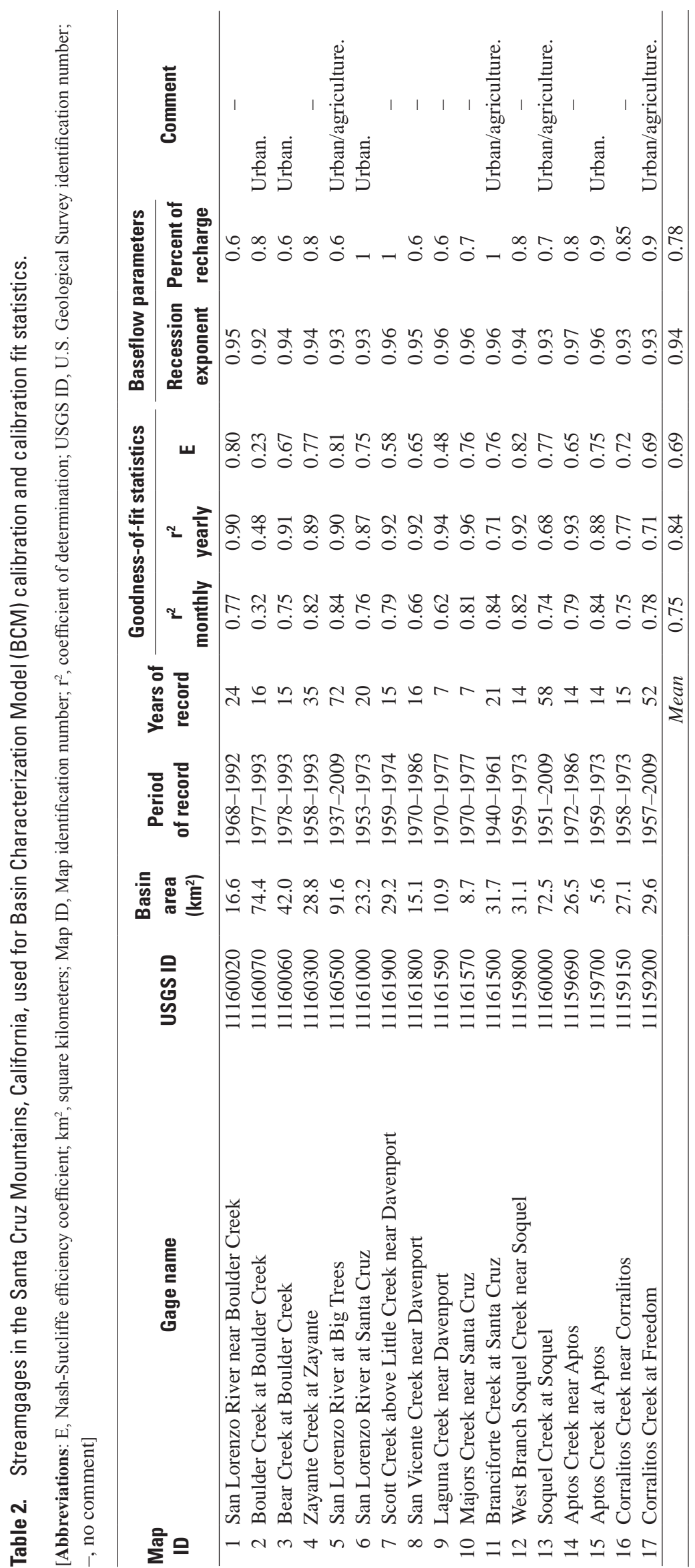




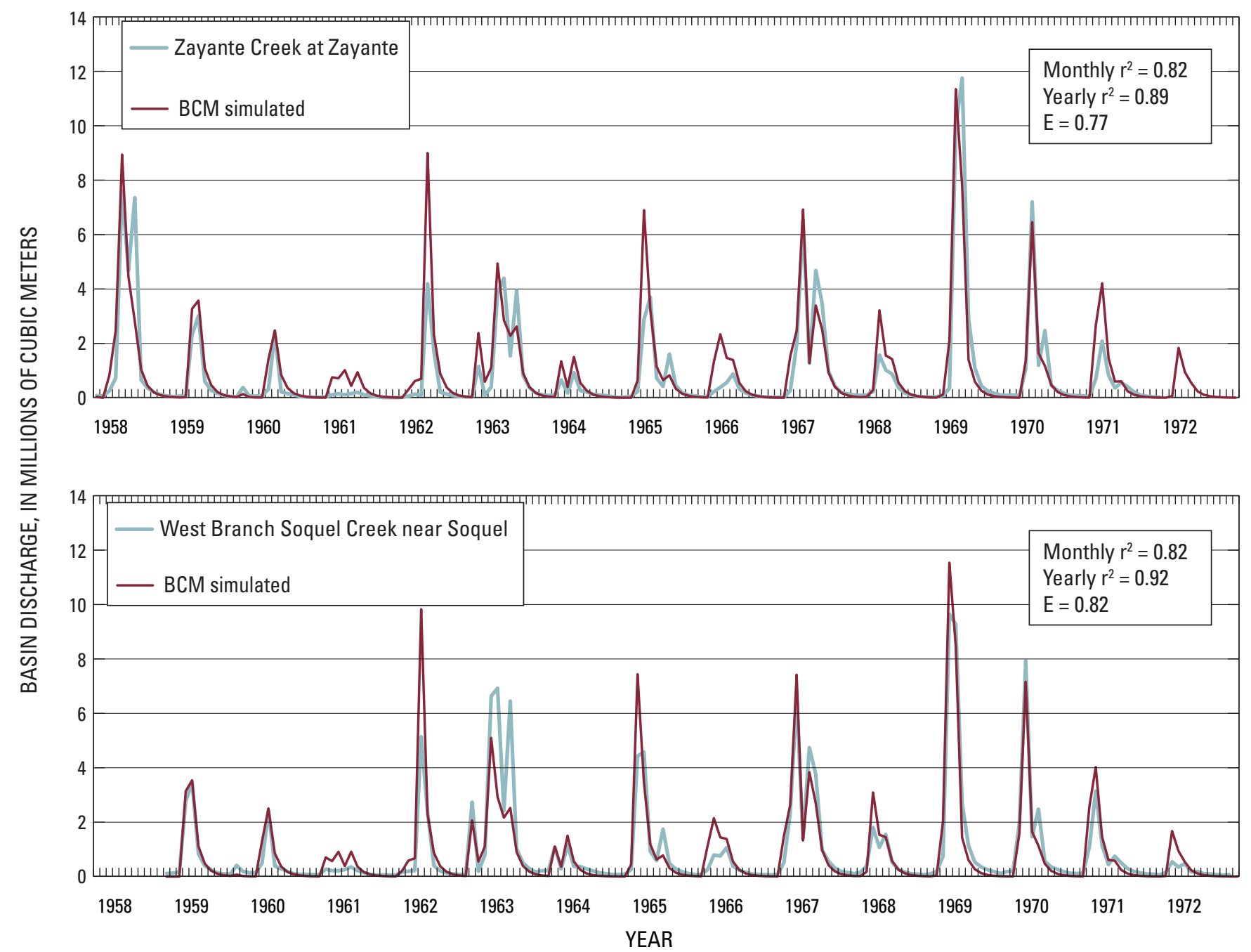

Figure 21. Examples of comparison of simulated to measured basin discharge for streamgages at Zayante Creek at Zayante and West Branch Soquel Creek near Soquel, California, from 1959 to 1972.

Potential effects of droughts are shown for Soquel Creek by using a 3-year running average for 90 years of historical basin discharge and 90 years of future discharge (fig. 23). As 3 sequential years of dry conditions are often declared a drought, this approach serves to illustrate any changes in future drought conditions. A dotted line is used to indicate a lower discharge threshold under which conditions could be considered a drought. Historically, about 4 to 5 droughts occurred in 90 years. Future projections include more than one drought every decade, with a multi-decadal drought for GFDL-A2 at the end of the 21st century.

The Santa Cruz drainage basin is dominated by groundwater and recharge zones, which are illustrated in figure 24 as outlined areas that are mapped recharge zones overlying the average annual recharge for 1971-2000 calculated by the BCM. Without routing, the BCM does not depict the recharge zones to be in the washes but in the locations where high precipitation, shallow soil, and permeable bedrock coincide. In this case, the high elevation locations in the Soquel Creek basin indicate high recharge. Whereas there can also be runoff that is generated at high elevations that ends up recharging in channels, the BCM does not indicate the processes that control lateral flow. The map does highlight the zone with the greatest recharge as the Santa Margarita sandstone (see geology map fig. 4) in the San Lorenzo River basin, which is coincident with the mapped recharge zones. Potential changes in recharge are shown in figure 25 as the change in recharge between 1971-2000 and 2071-2100. There is a reduction in recharge over most of the region, from 10-15 percent for the PCM model to 30 percent for the GFDL model for the A2 scenario, although slight increases occur in the San Lorenzo River basin recharge zone, as well as along the coastal plain, under both projections. 


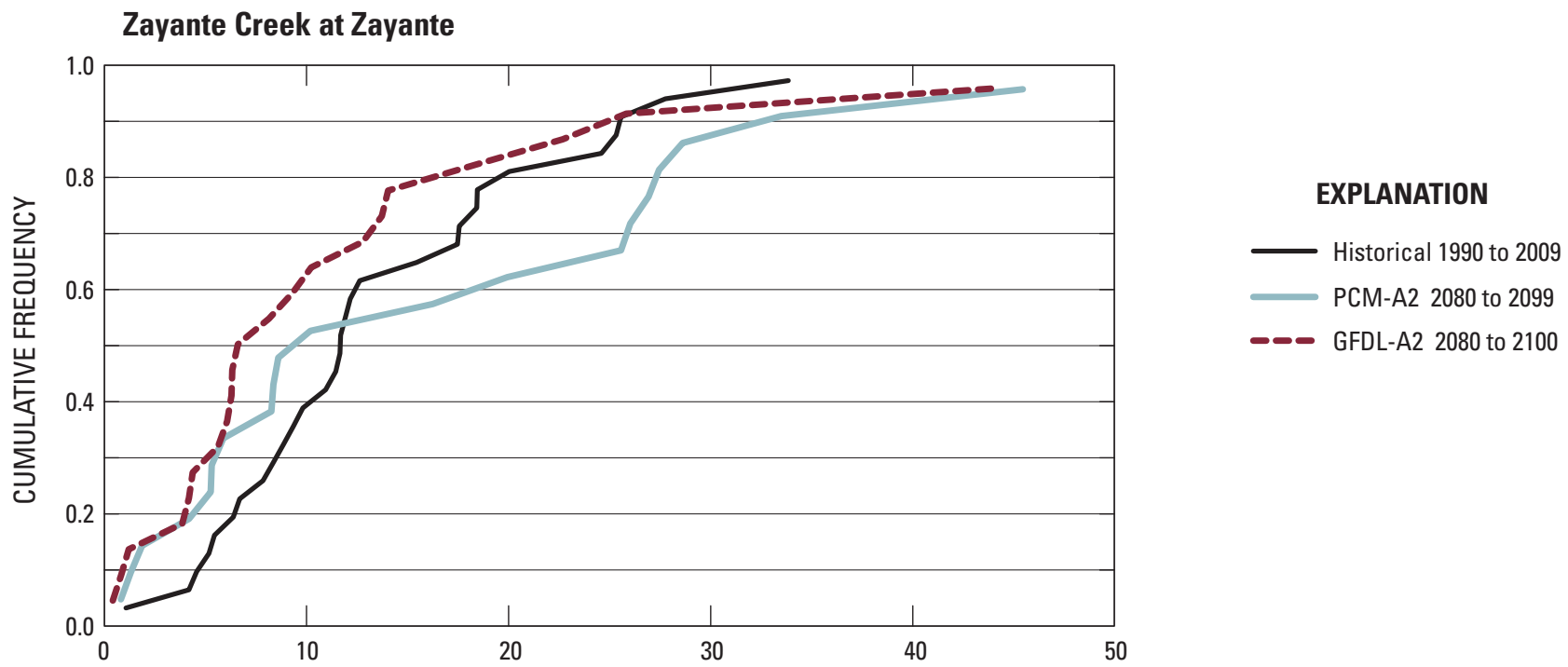

San Lorenzo River at Big Trees

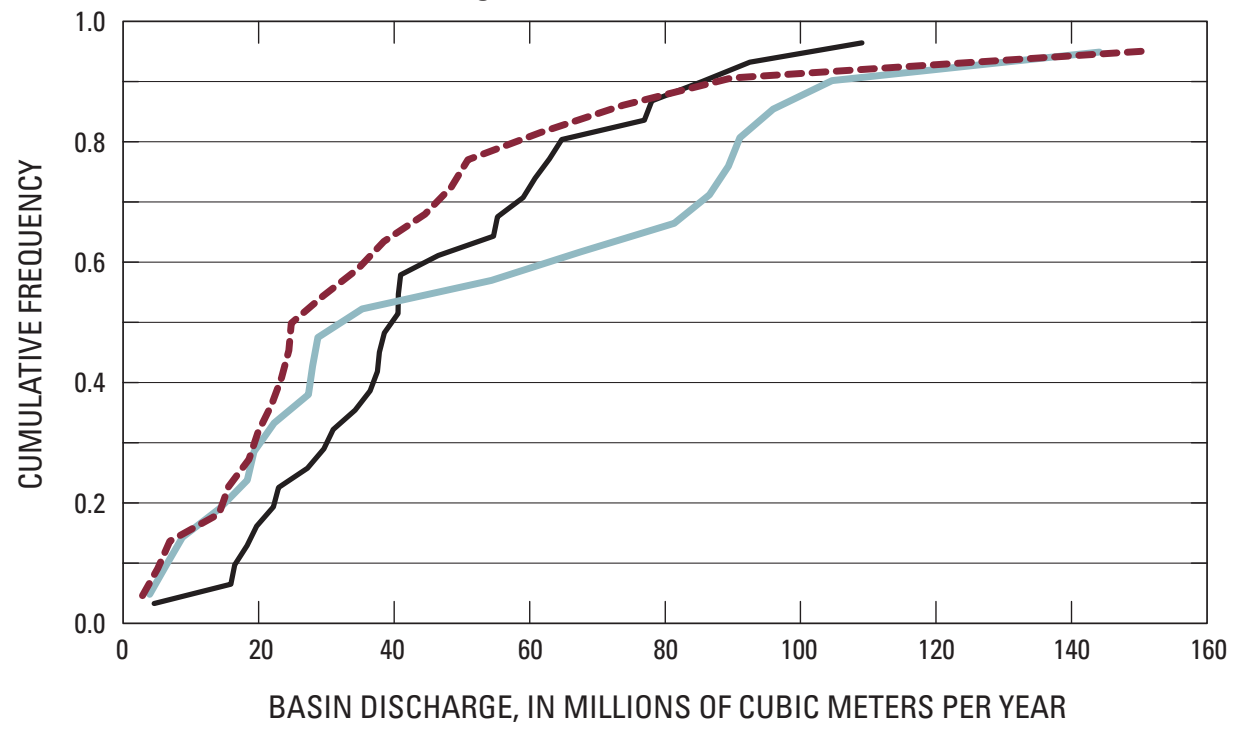

Figure 22. Cumulative frequency of basin discharge for two subbasins in the Sant Cruz Mountains, California, for 1971-2000 and for 2071-2100 as projected by GFDL-A2 and PCM-A2.

Seasonal changes in average monthly climate and hydrologic conditions between the ends of the 20th and 21st centuries are illustrated in figure 26. There is a shift in peak precipitation from January to February for both future projections, and both projections indicate less precipitation in the fall (November-December) and spring (March-April) in the future. Increases in seasonal potential evapotranspiration are projected, particularly in the summer months (JuneSeptember). Similar to precipitation, recharge shifts from a peak in January to a peak in February and shows large decreases in the fall under both projections, although the PCM shows increases and the GFDL decreases in March, which match their projected differences in precipitation. Runoff shows a pattern in timing that differs from precipitation for the GFDL-A2 projection, however, where there is no shift in monthly timing, but there is a reduction in runoff in the fall and spring. The PCM-A2 projection shows a much greater increase in runoff during the winter months, and the peak shift from January to February reflects projected changes timing of precipitation as well as increased runoff in the spring. 


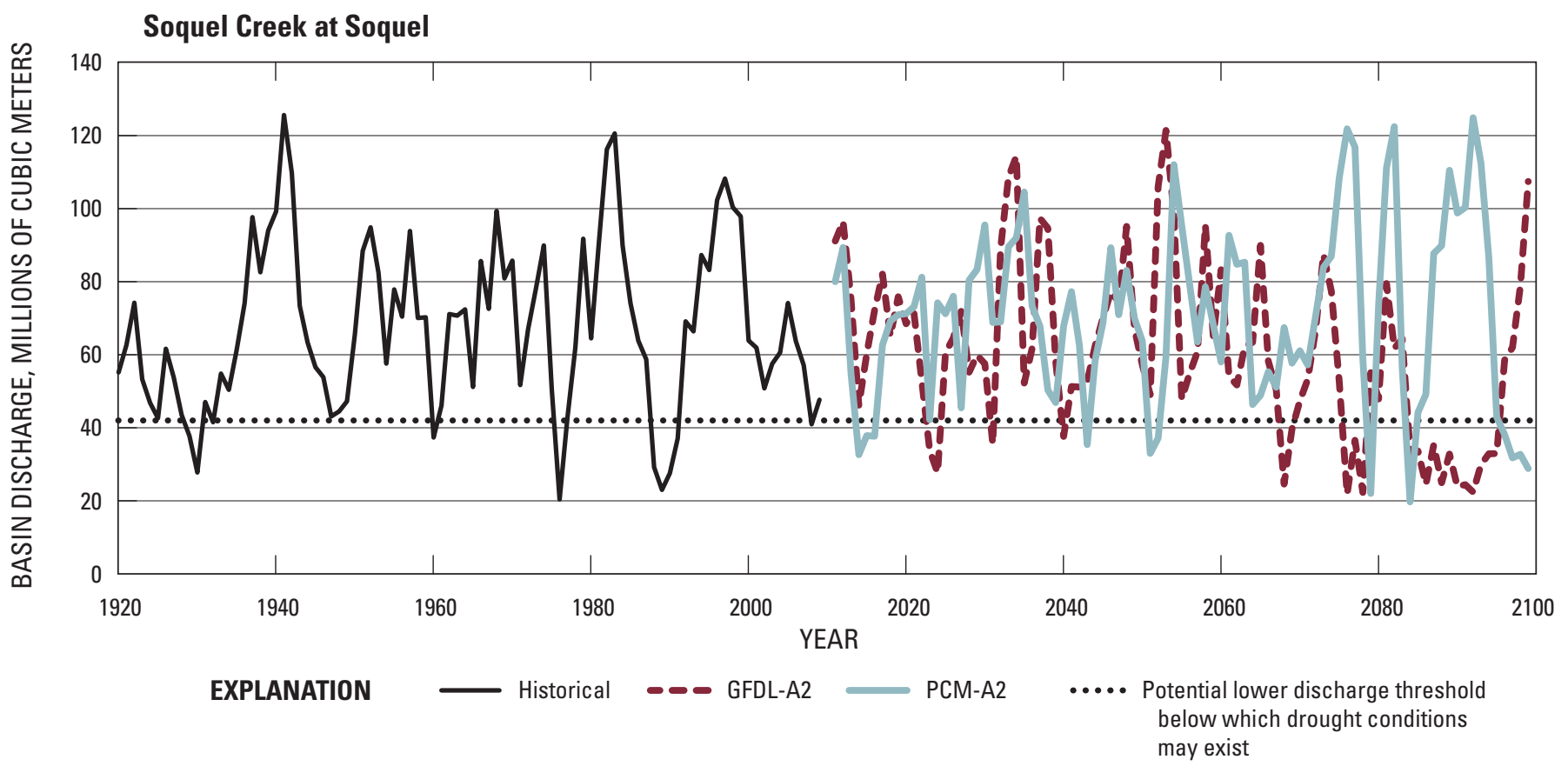

Figure 23. Basin discharge at Soquel Creek at Soquel, California, shown by historic and two projected 3-year running averages for $1920-2100$.

To provide quantitative values of historical and future estimates of climate and hydrology for major water supply basins in the Santa Cruz Mountains, mean values for 1971-2000 and 30-yr future periods for four projections for all components of the climate and water balance are shown in appendix 3. All drainages discharging to the San Lorenzo River, Branciforte Creek, Soquel Creek, Aptos Creek, and Correlitos Creek are included.

\section{Landscape Effects}

Increases in air temperature dominate the effects of climate change on the landscape, regardless of future changes in precipitation or water supply in the Santa Cruz Mountains. This is apparent through the application of CWD shown in figure 10, which is projected to increase from 4 to 25 percent in the Santa Cruz region, where redwood forest is the dominant vegetation type in the mountains (fig. 27A). The effect of potential changes in CWD on redwood forest distribution provides an excellent example of climate change effects on landscape. Based on the bioclimatic distribution for redwood forest ( $f$ ig. 11 ) and its range of suitable CWD, the historic (1971-2000) suitable habitat for redwood forest is found across the landscape (fig. 27A).
Because the A2 emissions scenario most closely matches the current measured greenhouse gas emission (fig. 3), the GFDL-A2 projection for 2071-2100 can be used to generate the distribution CWD showing suitable habitat in figure 27B. In this projection, there are no locations where CWD is in the lower 10 percent of the CWD distribution considered suitable for redwood forest, and there are some locations that exceed even the upper 10 percent of the CWD distribution. All locations suitable only to the upper 10 percent of the distribution are living at the extreme edge of their suitable range. Compared to the originally mapped redwood locations, suitable habitat for the middle 80 percent of the population is diminished to only locations on the north and northeast facing slopes. The GFDL-A2 example shows a dramatic effect on the redwood forests in this region. It also provides general locations that could receive management priorities for successful preservation. Certainly, multiple projections should be evaluated in future research efforts in this region to gain a better understanding of the range of potential changes to the landscape. 


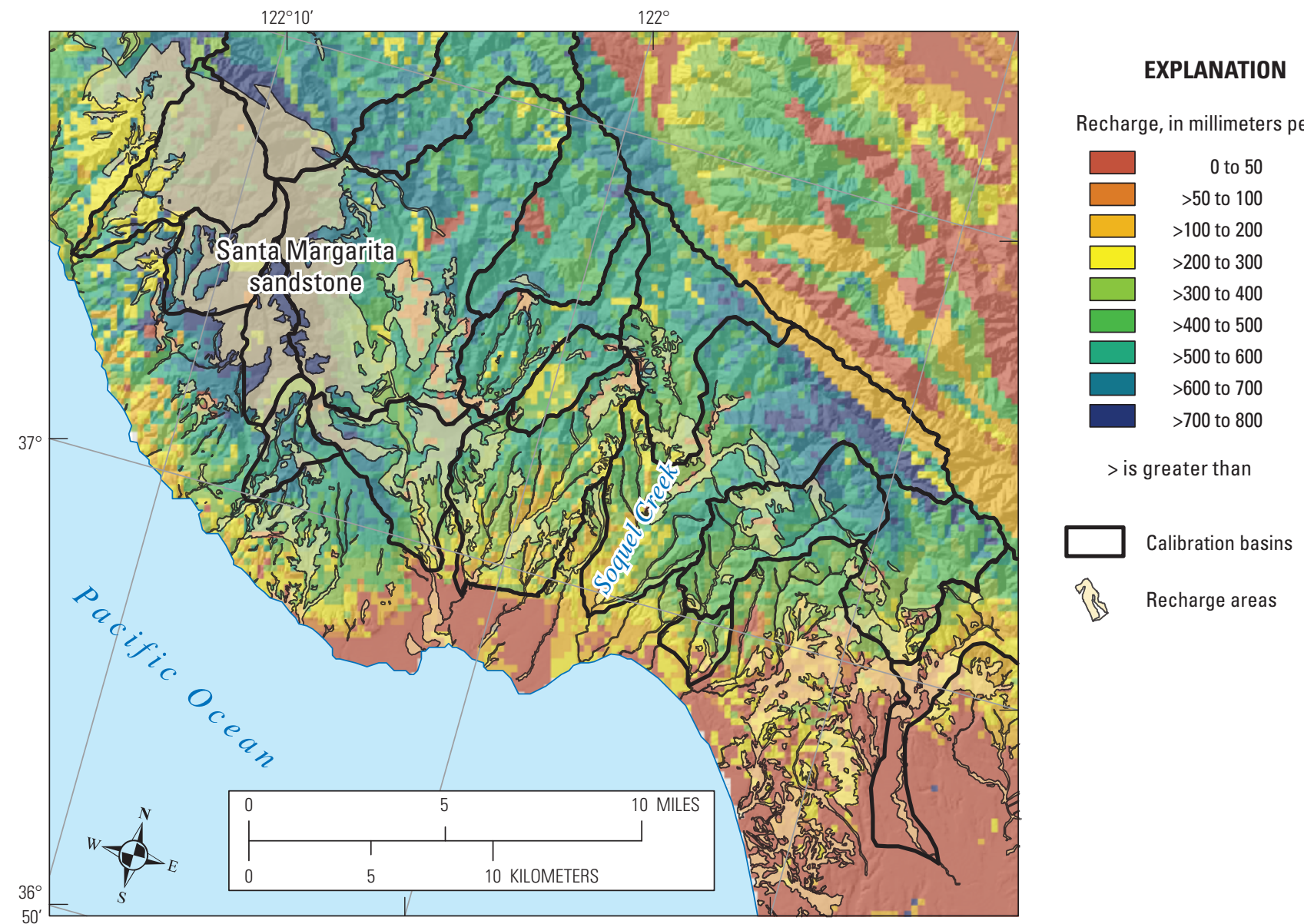

Figure 24. Recharge areas and associated contributing areas overlying historical recharge (1971-2000) estimate from the BCM for the Santa Cruz Mountains, California.

\section{Hydrologic Comparison of Russian River Valley and Santa Cruz Mountains}

By virtue of their respective positions in the regional landscape, the Russian River Valley and Santa Cruz Mountains have differing climate, geologic controls on the proportion of precipitation that becomes recharge or runoff, and land cover and land uses that result in variable hydrologic and environmental conditions that provide different options for managing and optimizing water resources. Both regions have strong coastal characteristics that moderate precipitation, and both showed increased precipitation during the last 30 years. Also, both areas have shown distinct warming trends in maximum and minimum air temperatures. Much more variability is found in the historical climate record for the Russian River Valley, however, than in the Santa Cruz Mountains, which lie directly on the coast. This can be explained partially by fog conditions and patterns along the coast. The presence of coastal fog in the coast redwood region has declined 33 percent over the 20th century (Johnstone and Dawson, 2010); however, it is unknown if this trend is likely to continue. The state-of-the-art in fog research and the ability to represent fog with climate models are improving rapidly, and historical maps of coastal fog for the Bay Area region have been assembled by Johnstone and Dawson (2010) to assist in developing process models that can be used to apply fog conditions to hydrologic models. Projections of coastal fog and its effects on hydrologic response, however, are not yet available.

The Russian River Valley is characterized by more alluvial fill in channels and valleys, whereas the Santa Cruz Mountains have more urbanized valleys and are characterized by more permeable bedrock. All of the physical and climatic features work in concert to produce the different hydrologic responses in the regions. 
$\boldsymbol{A}$

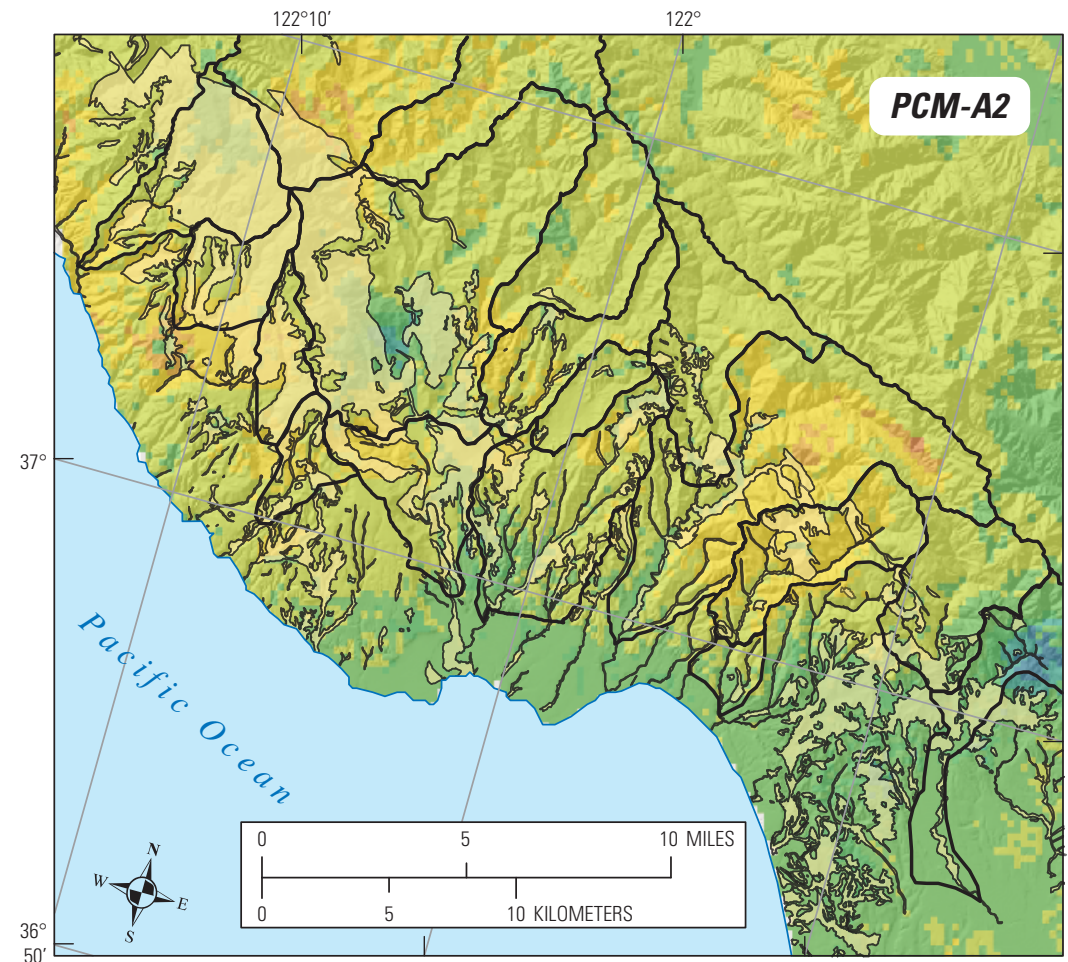

B

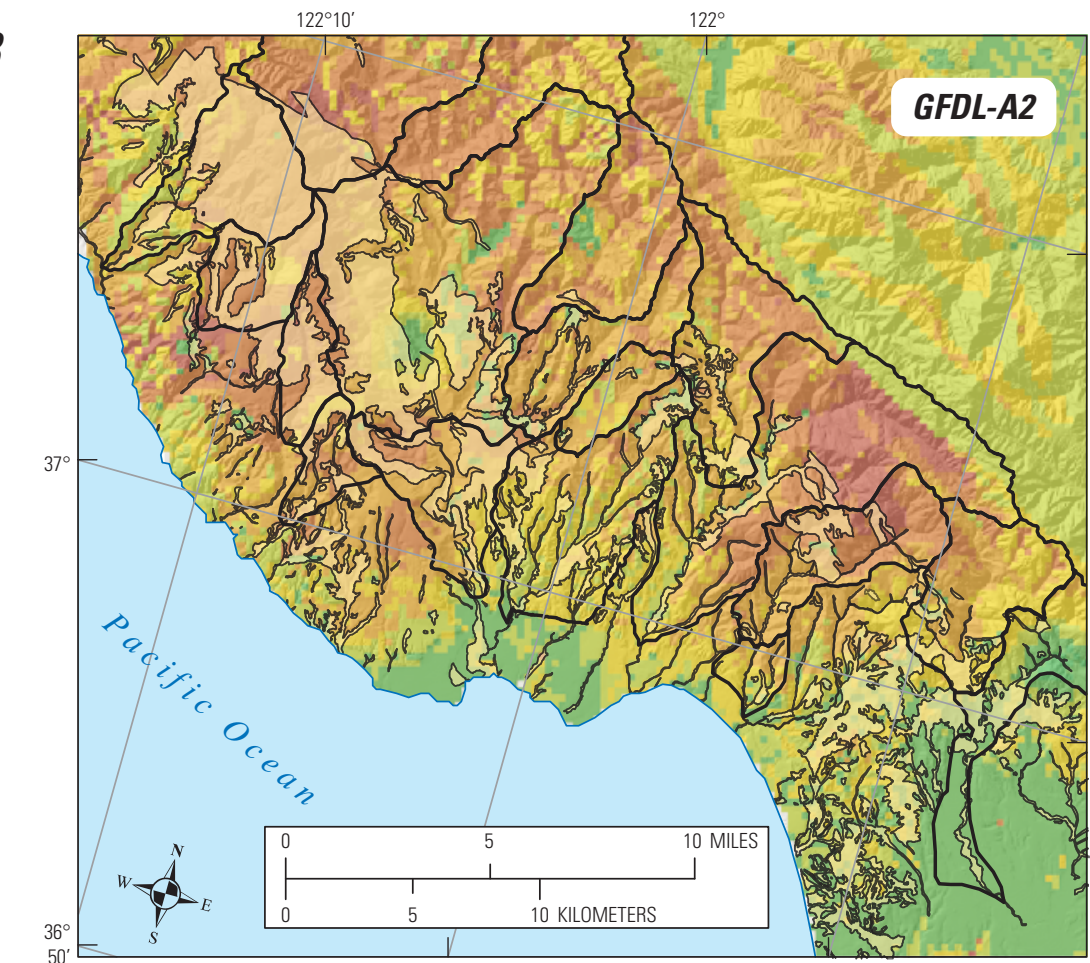

\section{EXPLANATION}

CHANGE IN RECHARGE, IN MILLIMETERS PER YEAR

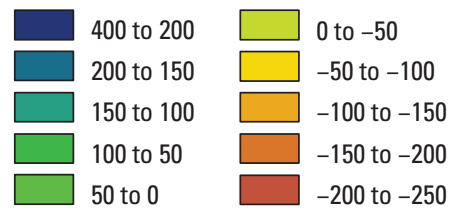

Calibration basins

? Recharge areas

Figure 25. Change in recharge between 1970-2000 and 2071-2100 for GFDL-A2 and PCM-A2 projections for the Santa Cruz Mountains, California. 

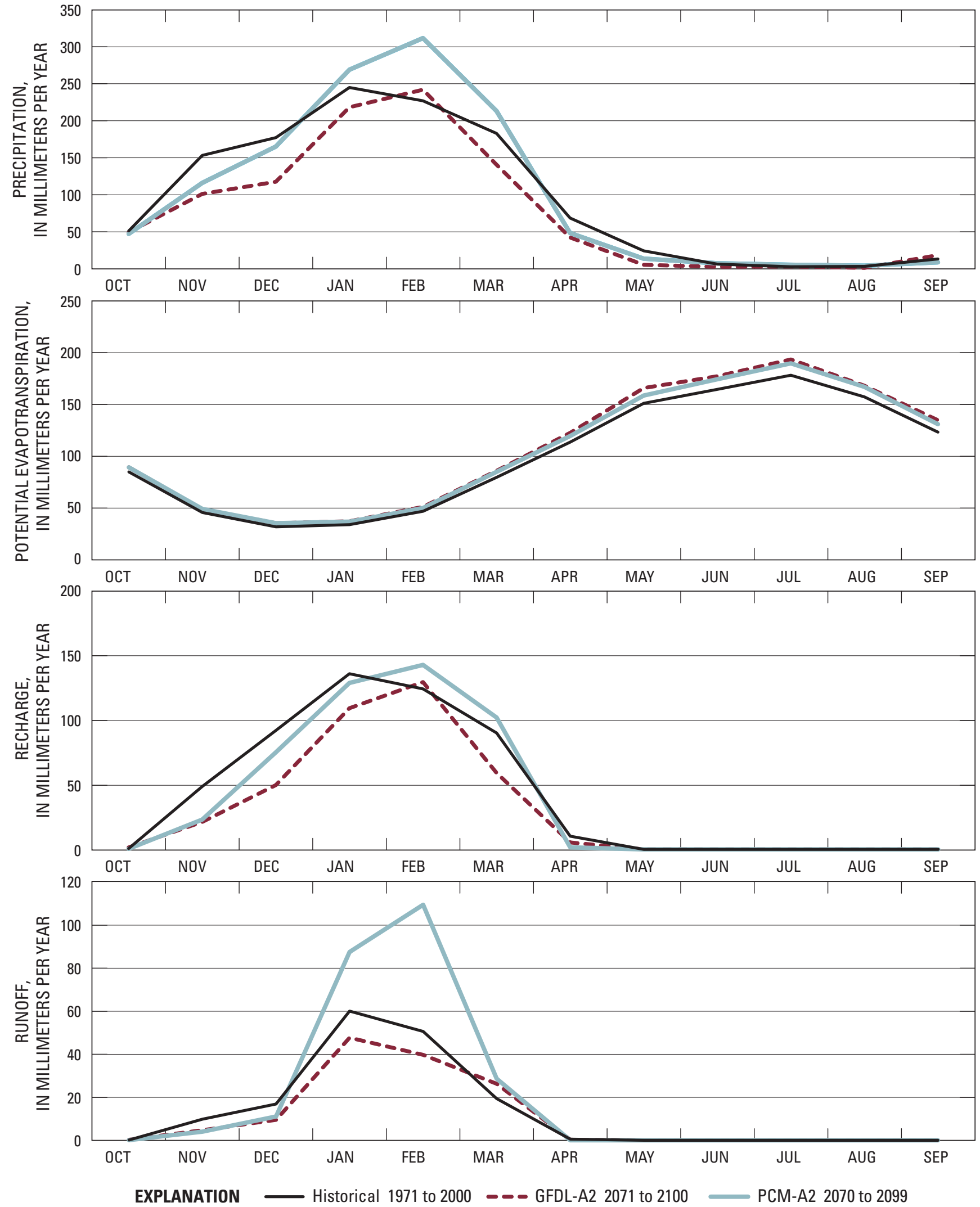

Figure 26. Mean 30-year monthly averages for precipitation, potential evapotranspiration, recharge, and runoff for current and two future projections for the Santa Cruz Mountains, California. 


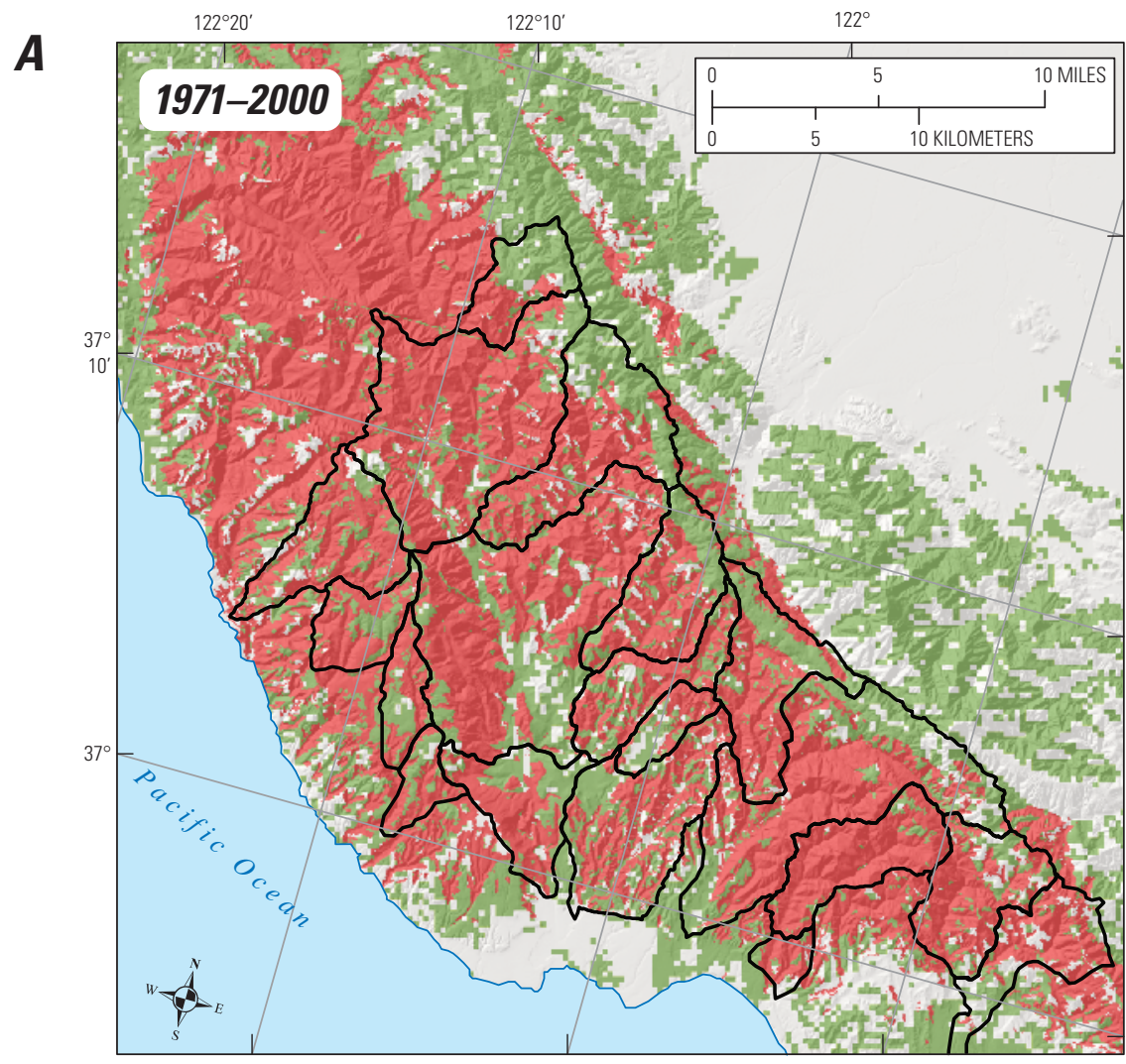

\section{EXPLANATION}

Distribution of suitable climatic water deficit

Distribution of mapped redwoods

B

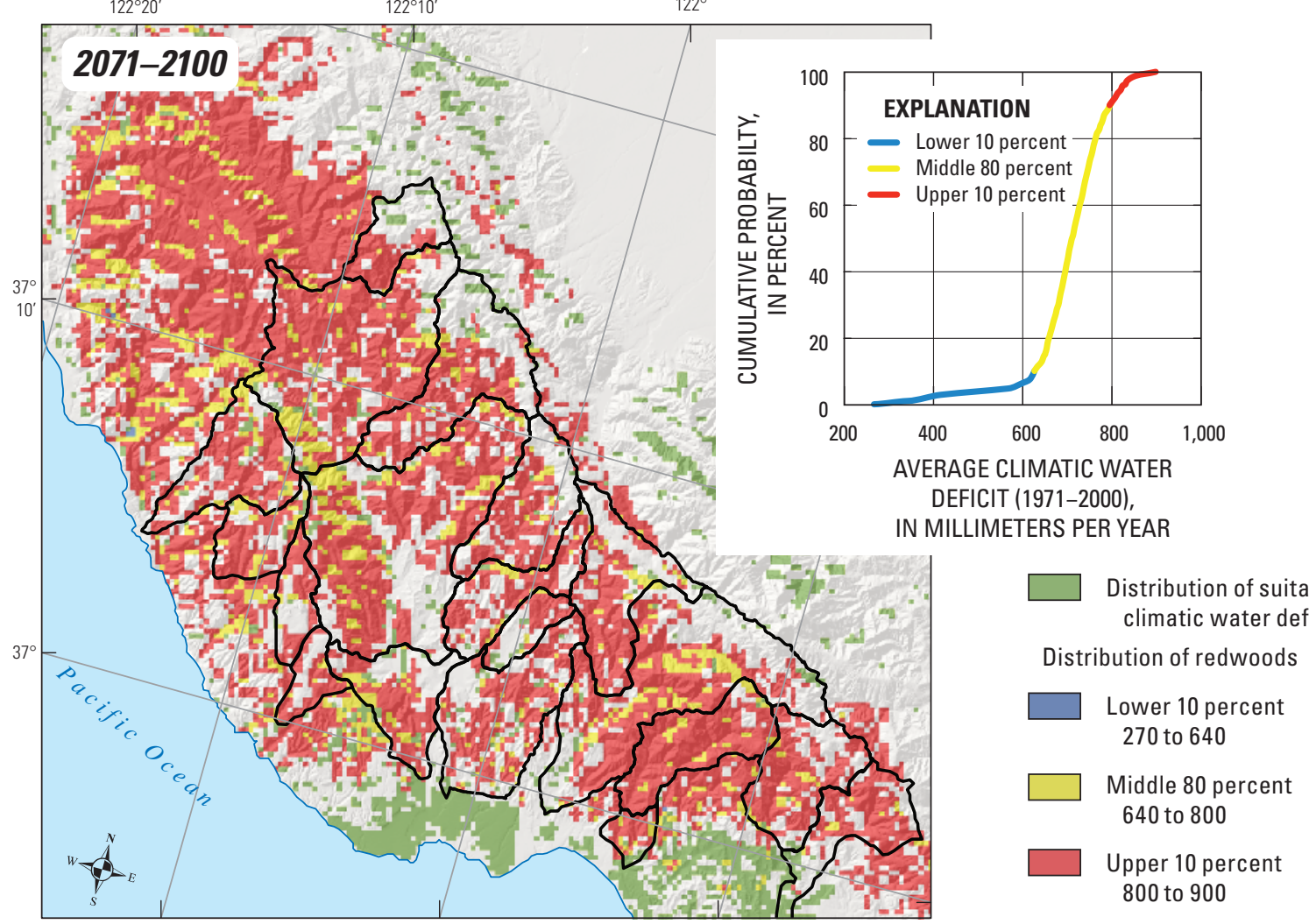

Figure 27. Redwood forest cover and area of average climatic water deficit suitable for redwood forest habitat in the Santa Cruz Mountains, California, $(A)$ for the historical period and $(B)$ projected for 2071-2100 in areas in which redwood forest currently lives, showing the middle 80 percent of the distribution and the upper and lower 10-percent tails. 
Future changes in basin discharge appear to be more dramatic in the Russian River Valley (fig. 15) than the Santa Cruz region (fig. 23) because the PCM-A2 projection is wetter there and the multi-decadal drought projected by the GFDL-A2 appears more extended in the Russian River Valley at the end of the century as well. More obvious differences in hydrologic responses to changes in climate though are related to the dominance of runoff in the Russian River Valley compared to the dominance of recharge in the Santa Cruz Mountains. The sensitivity of the Santa Cruz Mountains to changes in recharge is apparent in figure 9, where both moderate increases and dramatic decreases are projected in the future. The partitioning of precipitation into recharge and runoff is shown in figures 16 and 26, where approximately equal precipitation and potential evapotranspiration the Russian River Valley result in an average monthly peak recharge of $57 \mathrm{~mm} / \mathrm{yr}$, while the Santa Cruz Mountains have a peak recharge of $135 \mathrm{~mm} / \mathrm{yr}$. This contrasts with runoff, which peaks at about $112 \mathrm{~mm} / \mathrm{yr}$ for the Russian River Valley and at 58 for the Santa Cruz Mountains. The differences between the regions are also apparent in the changes in seasonal timing, where there are greater declines in fall and spring recharge, and a difference in the February runoff projections between the models resulting from differing winter patterns for Santa Cruz.

The effects of climate change on the landscape by the end of the century related to declines in redwood forest also differ between the two regions (figs. 19 and 27). Redwood forests are the dominant species in the Santa Cruz Mountains and cover over 90 percent of the non-urbanized landscape; based on the GFDL-A2 projection, by the end of the 21st century, a large proportion of locations currently occupied by redwood forest will increase in CWD to the upper extreme of suitable habitat, and less than 10 percent of redwood forest will remain within the middle 80 percent of their suitable CWD distribution. In contrast, the redwood forest in the Russian River Valley is a less extensive land cover, and it diminishes to just under half of its original range for the middle 80 percent of its bioclimatic distribution.

\section{Conclusions}

The San Francisco Bay Area has already experienced a warming trend over the 20th century, and monthly maximum temperatures have increased approximately $1^{\circ} \mathrm{C}$ between 1900 and 2000. The spatial distribution of climate change to date is variable, showing a trend toward warming of valley bottoms and, in some cases, cooling of montane areas. In general, coastal influences mitigate the warming trend, and effects are more pronounced with increasing distance from the Pacific coast or the bay. Projected temperature trends showed greater agreement than projected precipitation trends. The two climate models used in this study represent a range of potential future precipitation from longer drought conditions in the GFDL-A2 projection to a wetter future (approximately 20 percent more precipitation) in the PCM-A2 projection.

Hydrologic models predict reduced early and late wet season runoff during the next century, which potentially results in an extended dry season in both climate models. Projections that estimate increased precipitation show it concentrated in midwinter months, December and January, a trend that could increase risk of floods. In both the wetter and drier futures, potential evapotranspiration and associated climatic water deficit (CWD) are projected to steadily increase as much as 30 percent between the 2071-2100 period in comparison to the 1971-2000 period, which means approximately 200 millimeters of additional water needed on average to maintain current soil moisture conditions in some locations to maintain the current CWD levels. Summers are projected to be longer and drier in the future than in the past regardless of precipitation trends.

While water supply could be subject to increased variability (that is, reduced reliability) resulting from higher variability in precipitation, water demand is likely to steadily increase relative to increased rates of evapotranspiration and climatic water deficit during extended summers. Extended dry-season conditions and potential for extended drought combined with unprecedented precipitation events could serve as additional stressors on water quality and habitat. Realtime monitoring of hydrological variables can be one of the most prudent planning efforts and could be central to testing hypotheses about potential climate change demonstrated in this report and equipping managers to respond to climate adaptation challenges in a timely fashion.

\section{Implications for Resource Managers}

For adaptive resource management, it is important to develop projections by using models capable of accurately representing historical regional climate and hydrology. Physically-based basin models and finely downscaled climate projections can effectively represent environmental processes at regional and local scales and can be used with a range of representative climate projections to generate planning scenarios that incorporate climate effects on the water cycle. Assessing hydrologic response to climate change by using coupled climate-hydrologic modeling is necessary to understand the interrelationships of climate, energy, and water with topography and soils. These models benefit from using topography, soils, and geologic data at the finest spatial and temporal resolution available. 
While Global Climate Models (GCMs) generally agree on increasing air temperature projections for the region, they do not provide consistent projections regarding future precipitation, and therefore, they are the greatest source of uncertainty in this entire analysis. State-of-the-art GCMs continue to evolve to resolve discrepancies among models and provide future projections that more accurately reflect short-term and, therefore, long-term trends. It is important for basin managers to consider a range of future precipitation projections and potential effects on runoff and recharge, and to pay particular attention to the likelihood of increases in extremes.

By focusing on the relationship between soil moisture storage and evapotranspiration pressures, climatic water deficit (CWD) integrates the effects of increasing temperature and variable precipitation on basin conditions. At the finescale used for these analyses, this variable provided a useful picture of the areas in the landscape that are the most resilient or vulnerable to projected changes. These analyses showed that regardless of the direction of change of precipitation, climatic water deficit is projected to increase, implying more water needed to maintain current agricultural resources or land cover. The application of hydrologic models at fine spatial scales enhances the view of changes in the landscape and provides a spatially distributed view of locations that could prove to be persistent or resilient to changes in climate. Vegetation currently living on the edge of its present-day bioclimatic distribution is most likely to perish from future warming. These views can provide useful tools for better understanding of resources and to enable better prioritization for management and planning.

\section{References Cited}

Bay Area Open Space Council, 2011, San Francisco Bay Area upland habitat goals project - CLN vegetation types: San Francisco, Calif., Conservation Lands Network, GreenInfo Network, accessed June 2010, map available at $h t t p: / / w w w$. bayarealands.org/gis/

Bouwer, L.M.; Aerts, J.C.; Van de Coterlet, G.M.; Van de Giesen, Nick; Gieske, Ambro; and Mannaerts, Chris, 2004, Evaluating downscaling methods for preparing global circulation model (GCM) data for hydrological impact modeling, chap. 2 in Aerts, J.C., and Droogers, Peter, eds., Climate change in contrasting river basins: London, United Kingdom, CAB International Publishing, p. 25-47.

Cayan, D.R.; Maurer, E.P.; Dettinger, M.D.; Tyree, Mary; and Hayhoe, Katharine, 2008, Climate change scenarios for the California region: Climatic Change, v. 87, p. 21-47, DOI 10.1007/s10584-007-9377-6.
Cayan, D.R.; Tyree, Mary; Dettinger, M.D.; Hidalgo, Hugo; and Das, Tapash, 2009, California climate change scenarios and sea level rise estimates for the California 2008 Climate Change Scenarios Assessment: California Energy Commission Report No. CEC-500-2009-014-F. Available at http://www.energy.ca.gov/2009publications/CEC-500-2009014/CEC-500-2009-014-F.PDF

Daly, Christopher; Gibson, W.P.; Doggett, Matt; Smith, Joseph; and Taylor, George, 2004, Up-to-date monthly climate maps for the conterminous United States: American Meteorological Society Conference on Applied Climatology, January 13-16, 2004, 14 ${ }^{\text {th }}$, Seattle, Wash.,

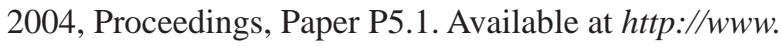
prism.oregonstate.edu/pub/prism/docs/appclim04-uptodate monthly_climate_maps-daly.pdf

Delworth, T.L., and others, 2006, GFDL's CM2 global coupled climate models-Part 1: Formulation and simulation characteristics: Journal of Climate, v. 19, no. 5, p. 643-674.

Flint, A.L., and Flint, L.E., 2007a, Application of the Basin Characterization Model to estimate in-place recharge and runoff potential in the Basin and Range carbonaterock aquifer system, White Pine County, Nevada, and adjacent areas in Nevada and Utah: U.S. Geological Survey Scientific Investigations Report 2007-5099, 20 p. Available at http://pubs.water.usgs.gov/sir20075099

Flint, L.E., and Flint, A.L., 2007b, Regional analysis of ground-water recharge, chap. B in Stonestrom, D.A., Constantz, J., Ferré, T.P.A., and Leake, S.A., eds., 2007, Ground-water recharge in the arid and semi-arid southwestern United States: U.S. Geological Survey Professional Paper 1703, p. 29-60. Available at http://pubs. usgs.gov/pp/pp1703/

Flint, L.E, and Flint, A.L., 2012, Downscaling future climate scenarios to fine scales for hydrologic and ecological modeling and analysis: Ecological Processes, v. 1, no. 1.

Flint, A.L., Flint, L.E., and Masbruch, M.D., 2011, Input, calibration, uncertainty, and limitations of the Basin Characterization Model, app. 3 in Heilweil, V.M., and Brooks, L.E., eds., 2011, Conceptual model of the Great Basin carbonate and alluvial aquifer system: U.S. Geological Survey Scientific Investigations Report 20105193.

Hellman, J.J., Weiss, S.B., McLaughlin, J.F., Ehrlich, P.R., Murphy, D.D., and Launer, A.E., 2004, Structure and dynamics of Euphydryas editha populations, chap. 3 in Ehrlich, P.R., and Haanski, Ilkka, eds., On the wings of Checkerspots: a model system for population biology: New York, N.Y., Oxford University Press, p. 34-62. 
Hidalgo, Hugo, Dettinger, M.D., and Cayan, D.R., 2008, Downscaling with constructed analogues: Daily precipitation and temperature fields over the United States: California Energy Commission Report No. CEC-500-2007123. Available at http://meteora.ucsd.edu/cap/pdffiles/ analog_pier_report.pdf

Intergovernmental Panel on Climate Change, 2001, Climate change 2001 - The third assessment report (AR3) of the United Nations Intergovernmental Panel on Climate Change: New York, N.Y., Cambridge University Press. Available at http://www.ipcc.ch/publications_and_data/ publications_and_data_reports.htm

Intergovernmental Panel on Climate Change, 2007, Climate Change 2007-The fourth assessment report (AR4) of the United Nations Intergovernmental Panel on Climate Change: New York, N.Y., Cambridge University Press. Available at http://www.ipcc.ch/publications_and_data/ publications_and_data_reports.htm

Johnstone, J.A., and Dawson, T.E., 2010, Climatic context and ecological implications of summer fog decline in the coast redwood region: Proceedings of the National Academy of Sciences of the United States of America, v. 107, no. 10, p. 4533-4538, supporting information available at $w w w$. pnas.org/cgi/content/full/0915062107/DCSupplemental

Knowles, Noah, and Cayan, Daniel, 2002, Potential effects of global warming on the Sacramento/San Joaquin watershed and the San Francisco Estuary: Geophysical Research Letters, v. 29, no. 18, p. 38-1-38-4. Available at http://www. agu.org/pubs/crossref/2002/2001GL014339.shtml

Legates, D.R., and McCabe, G.J., Jr., 1999, Evaluating the use of "goodness-of-fit" measures in hydrologic and hydroclimatic model validation: Water Resources Research, v. 35, no. 1, p. 233-241.

Loarie, S.R., and Ackerly, D.D., 2004, The distribution of California's endangered plants in multivariable climate space: $6^{\text {th }}$ Annual Bay Area Conservation Biology Symposium.

Lundquist, J.D., Dettinger, M.D., Stewart, I.T., and Cayan, D.R., 2009, Variability and trends in spring runoff in the western United States, chap. 5 in Environmental effects: Twentieth-century observations and twenty-first century projections, Part II. of Wagner, Frederic, ed., 2009, Climate warming in western North America-Evidence and environmental effects: Salt Lake City, Utah, University of Utah Press, p. 63-76.
McCarthy, J.J., 2009, Reflections on: our planet and its life, origins, and futures: Science, v. 326, no. 5960, p. $1646-$ 1655.

Meehl, G.A., Washington, W.M., Wigley, T.M.L., Arblaster, J.M., and Dai, Aiguo, 2003, Solar and greenhouse gas forcing and climate response in the twentieth century: Journal of Climate, v. 16, no. 3, p. 426-444.

Nakićenović, Nebojša, and Swart, Rob, eds., 2000, Special Report on Emissions Scenarios: A special report of Working Group III of the Intergovernmental Panel on Climate Change: New York, N.Y., Cambridge University Press, [variously paged].

Nalder, I.A., and Wein, R.W., 1998, Spatial interpolation of climatic normals: Test of a new method in the Canadian boreal forest: Agricultural and Forest Meteorology, v. 92, no. 4, p. 211-225.

Nash, J.E., and Sutcliffe, J.E., 1970, River flow forecasting through conceptual model: Journal of Hydrology, v. 10, no. 3, p. 282-290.

Natural Resources Conservation Service, 2006, U.S. General Soil Map (STATSGO2): U.S. Department of Agriculture, accessed [date]. Available at http://soildatamart.nrcs.usda. gov

Stephenson, N.L., 1998, Actual evapotranspiration and deficit: Biologically meaningful correlates of vegetation distribution across spatial scales: Journal of Biogeography, v. 25, no. 5, p. 855-870.

Stouffer, R.J., and others, 2006, GFDL's CM2 global coupled climate models. Part IV: Idealized climate response: Journal of Climate, v. 19, no. 5, p. 723-740.

Washington, W.M., Weatherly, J.W., Meehl, G.A., Semtner, A.J., Bettge, T.W., Craig, A.P., Strand, W.G., Arblaster, J.M., Wayland, V.B., James, R., and Zhang, Y., 2000, Parallel climate model (PCM) control and transient simulations: Climate Dynamics, v. 16, no. 10/11, p. 755-774. 


\section{Appendix 1}

Mean 30-Year Values for Climate and Water-Balance Components for Current and Four Future Projections for Major Water Supply Basins in the Russian River Valley, California 


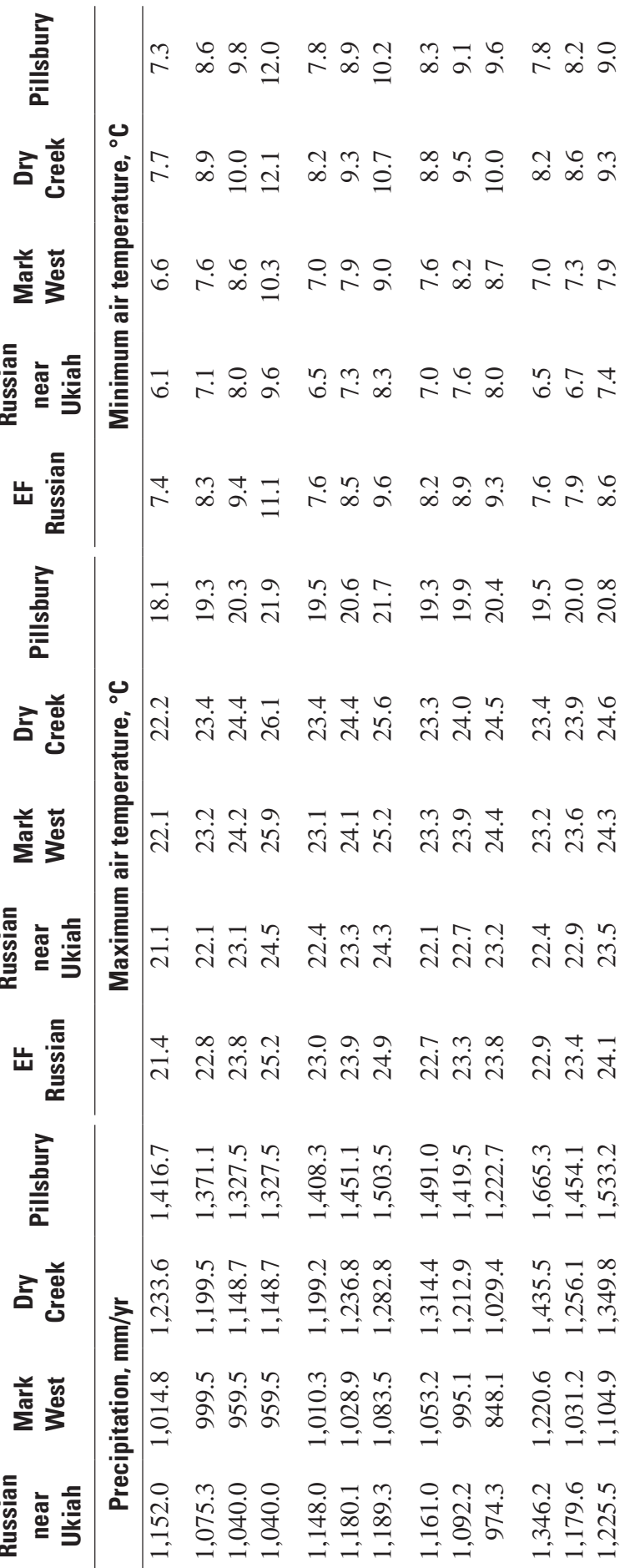

出高

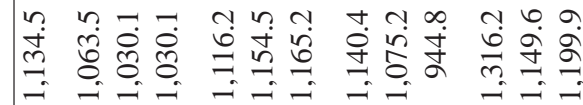

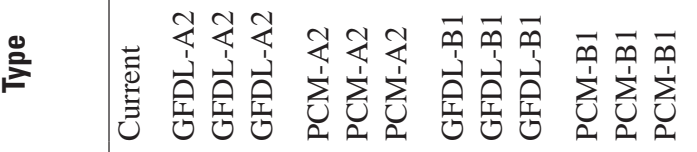

흥

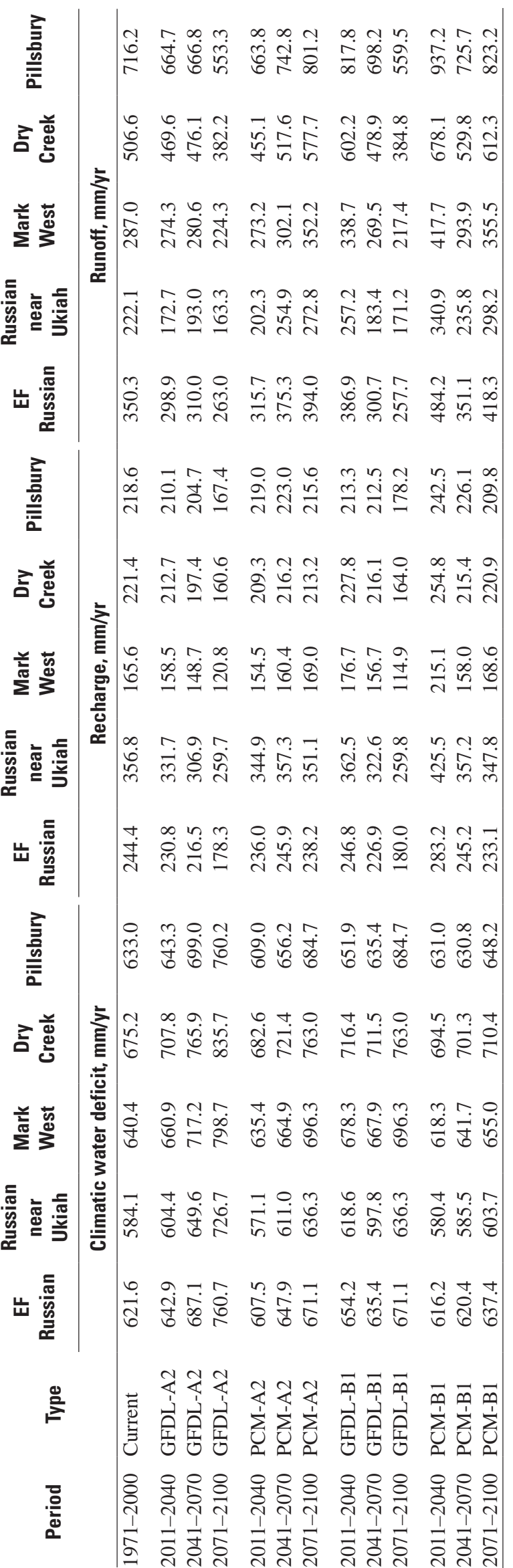




\section{Appendix 2}

Cumulative Frequency of Basin Discharge for All Basins in the Santa Cruz Mountains, California 


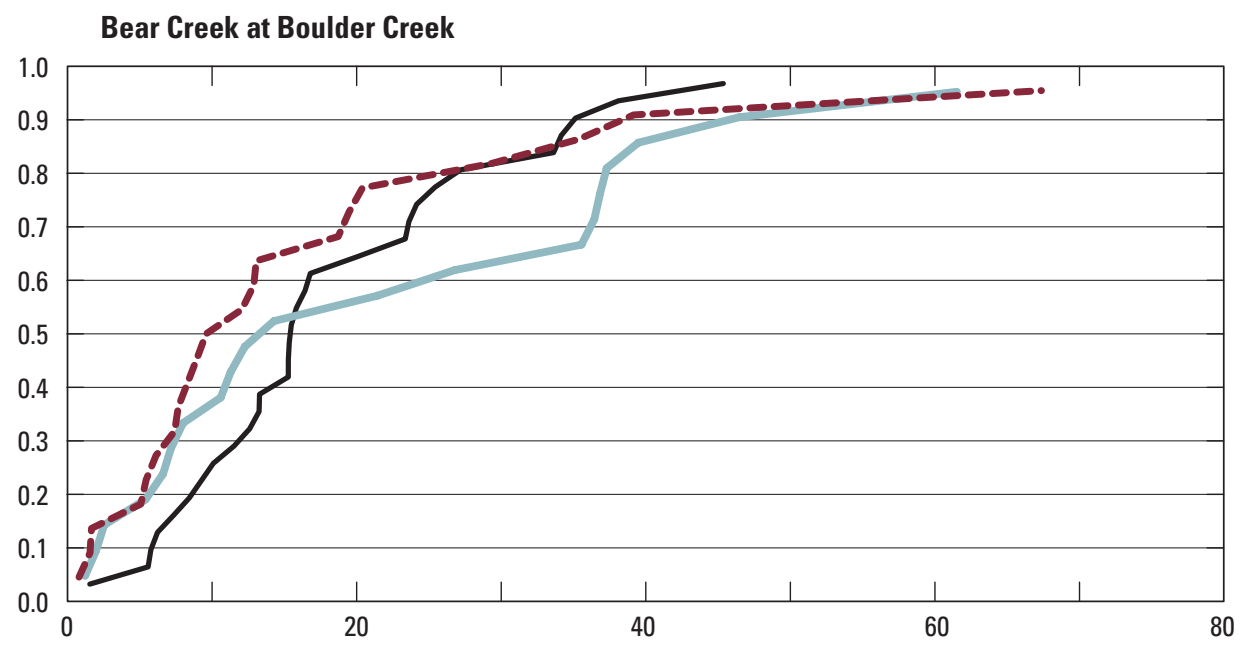

\section{EXPLANATION}

Historical 1990 to 2009

PCM-A2 2080 to 2099

GFDL-A2 2080 to 2100

Boulder Creek at Boulder Creek

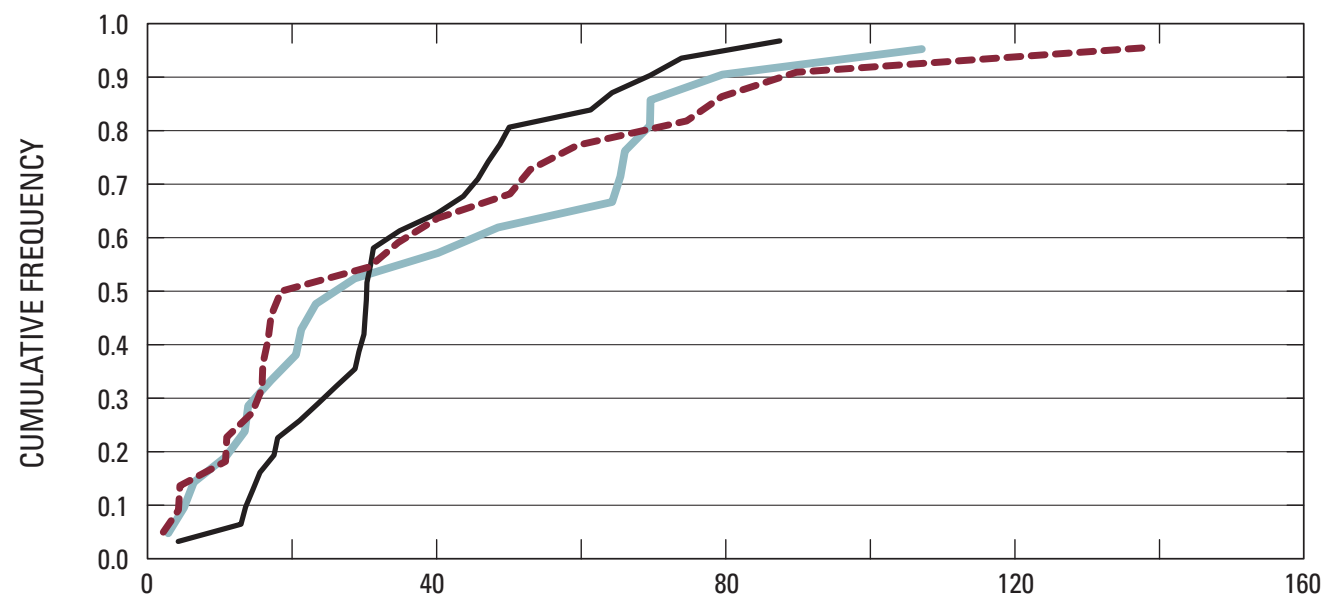

San Lorenzo River near Boulder Creek

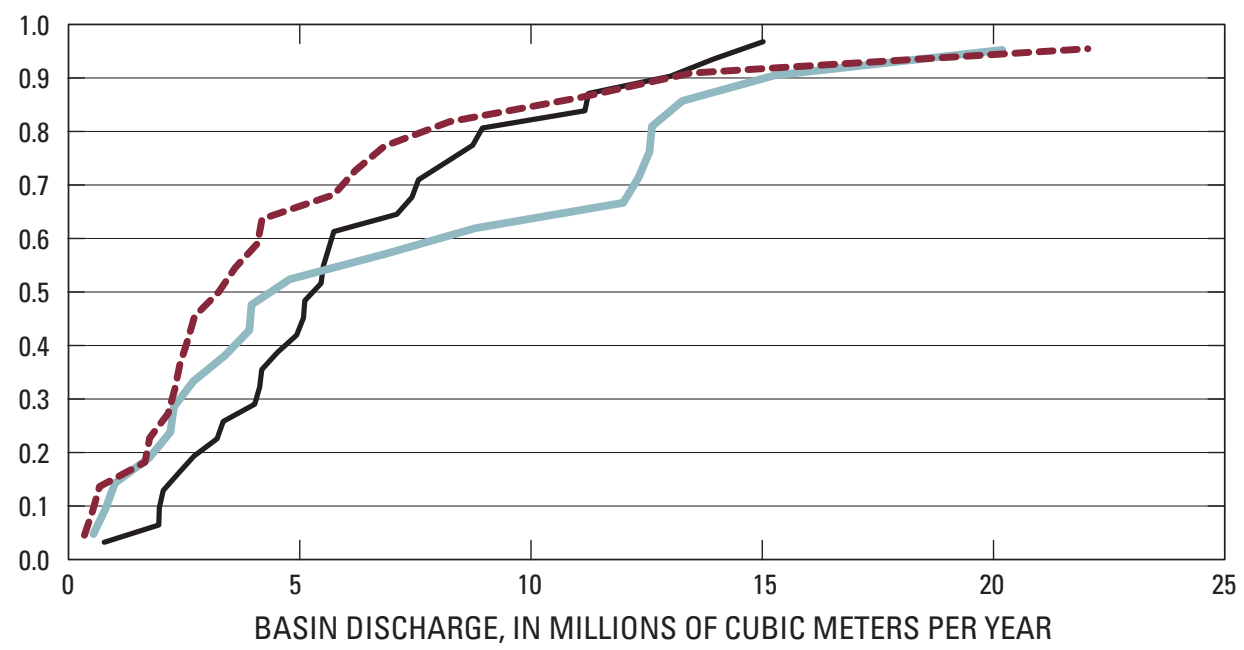




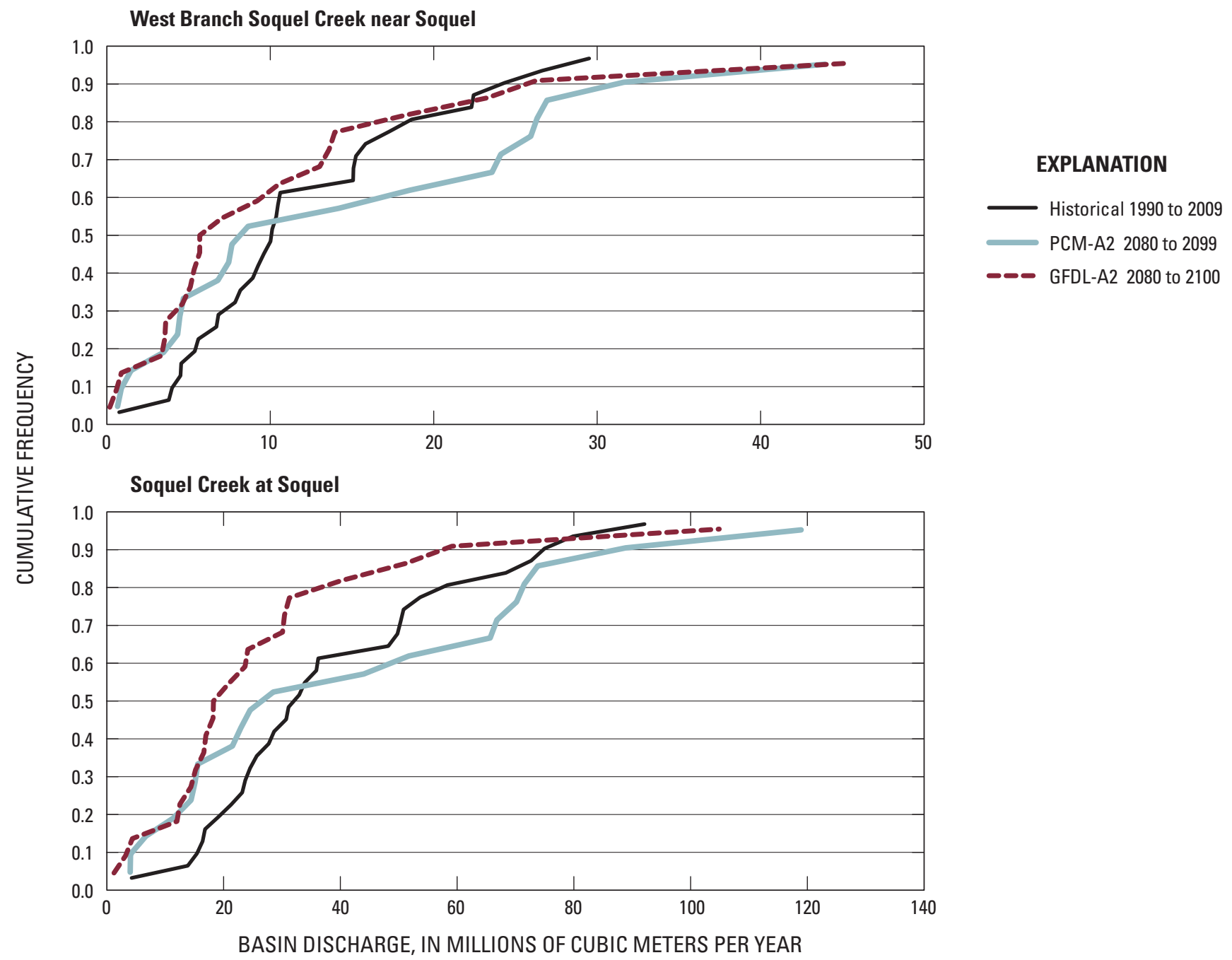




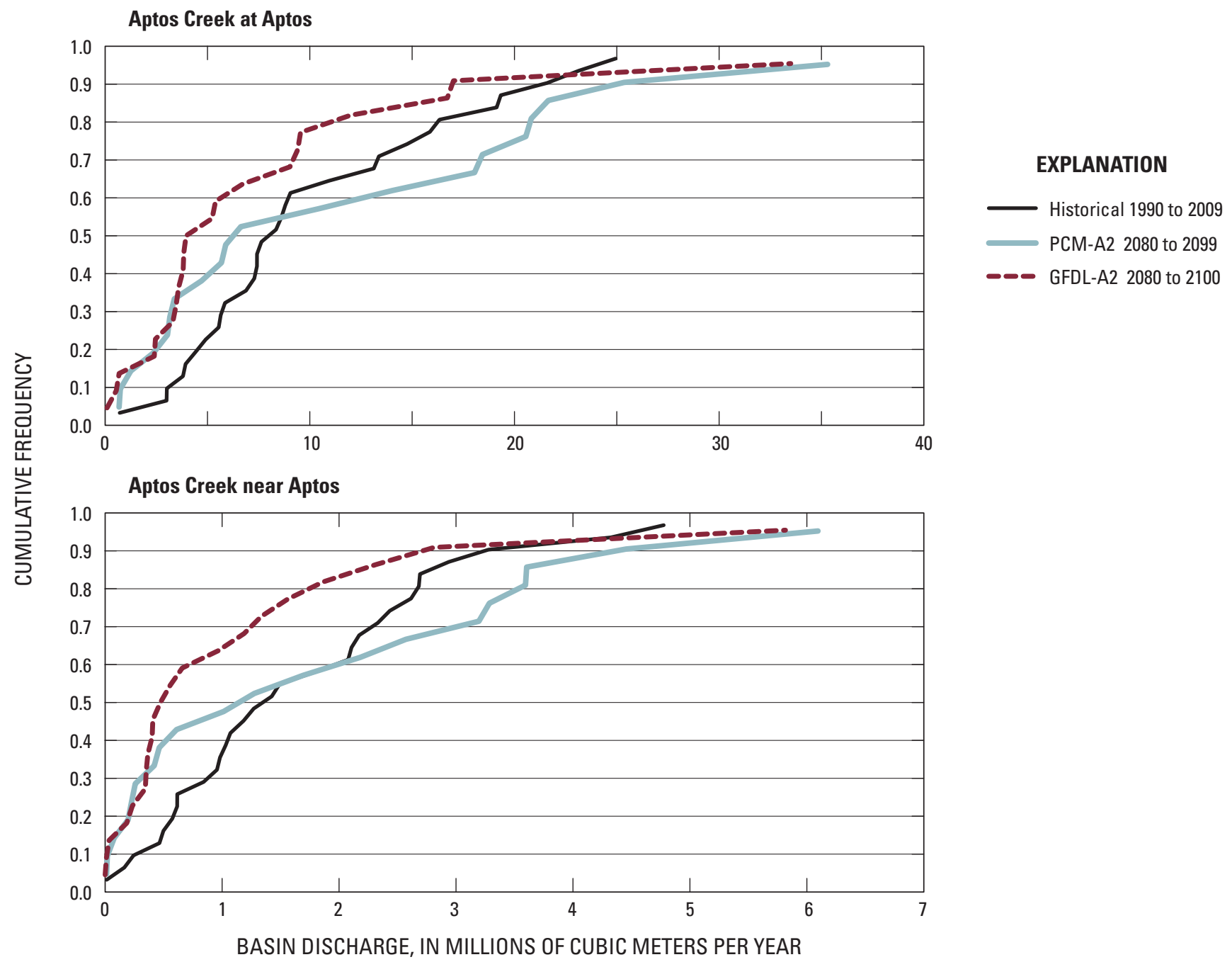




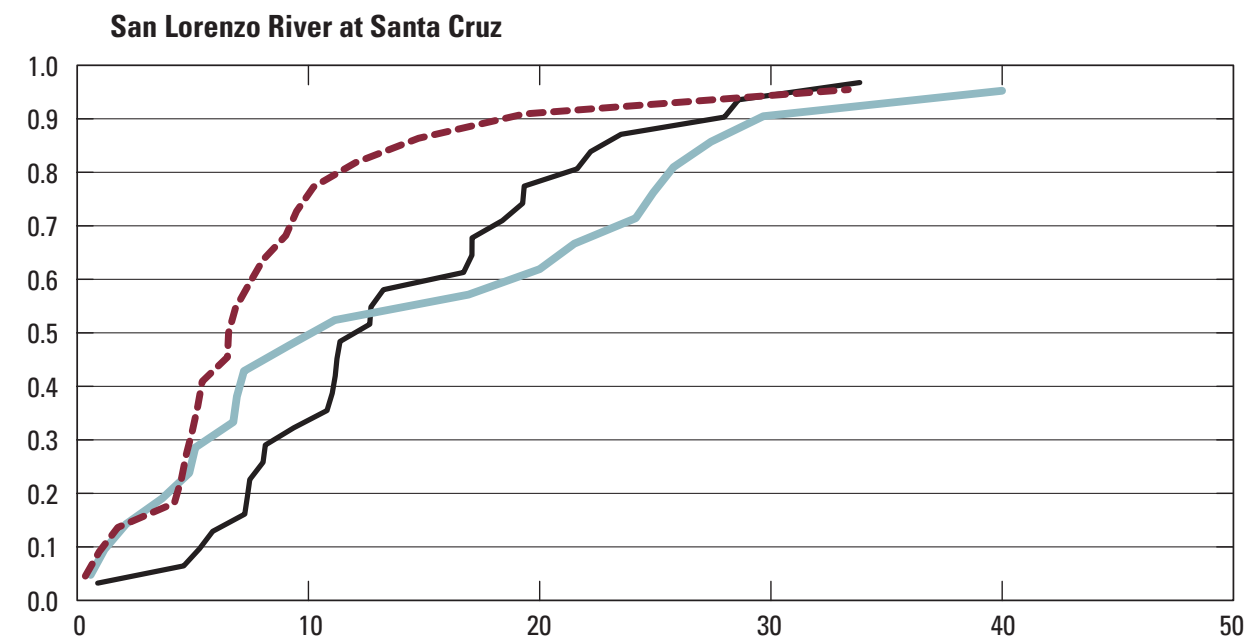

\section{EXPLANATION}

Historical 1990 to 2009

PCM-A2 2080 to 2099

GFDL-A2 2080 to 2100

Branciforte Creek at Santa Cruz

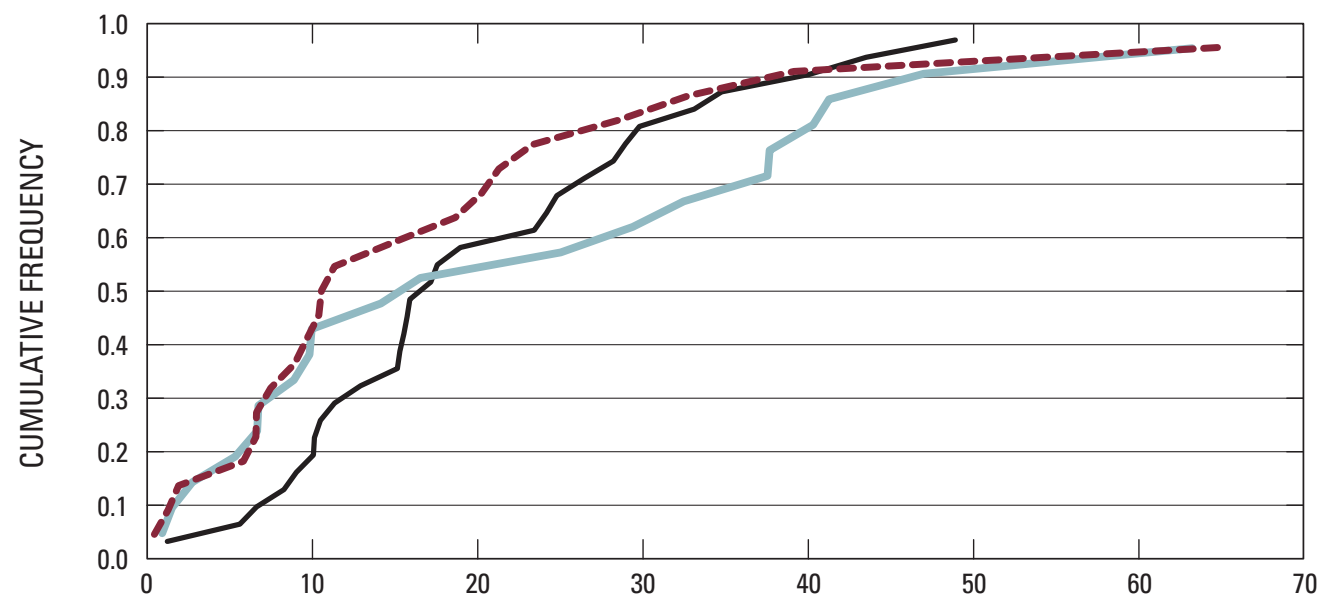

Scott Creek above Little Creek near Davenport

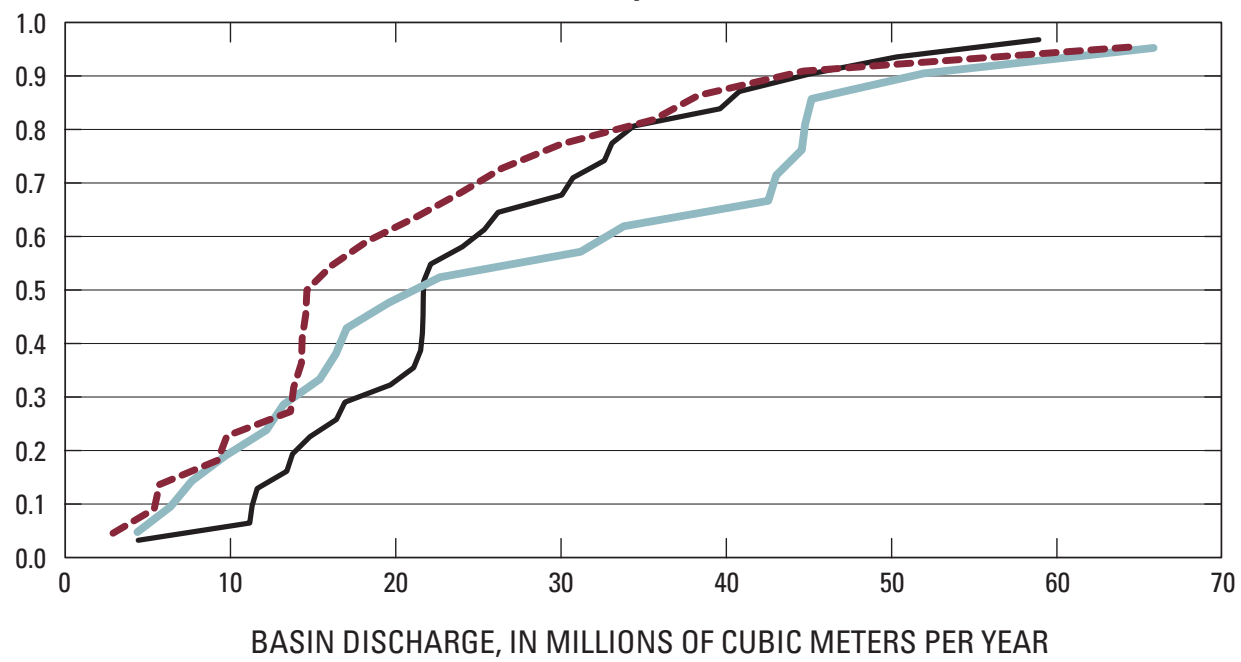




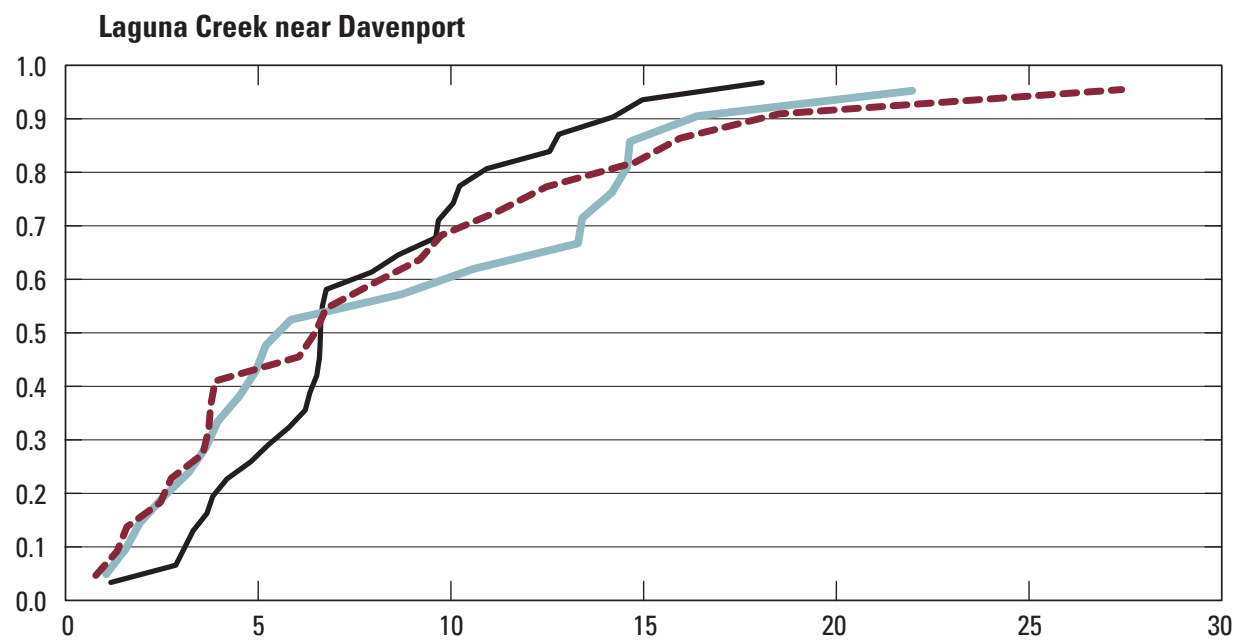

\section{EXPLANATION}

Historical 1990 to 2009

PCM-A2 2080 to 2099

GFDL-A2 2080 to 2100

San Vicente Creek near Davenport

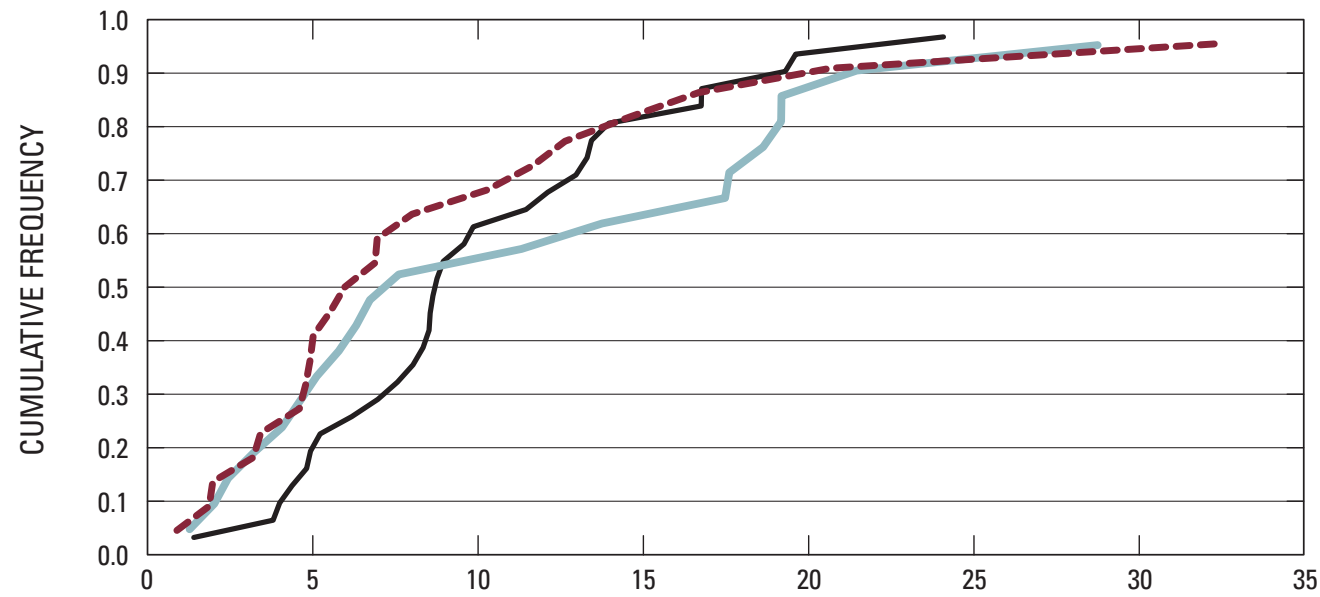

Majors Creek near Santa Cruz

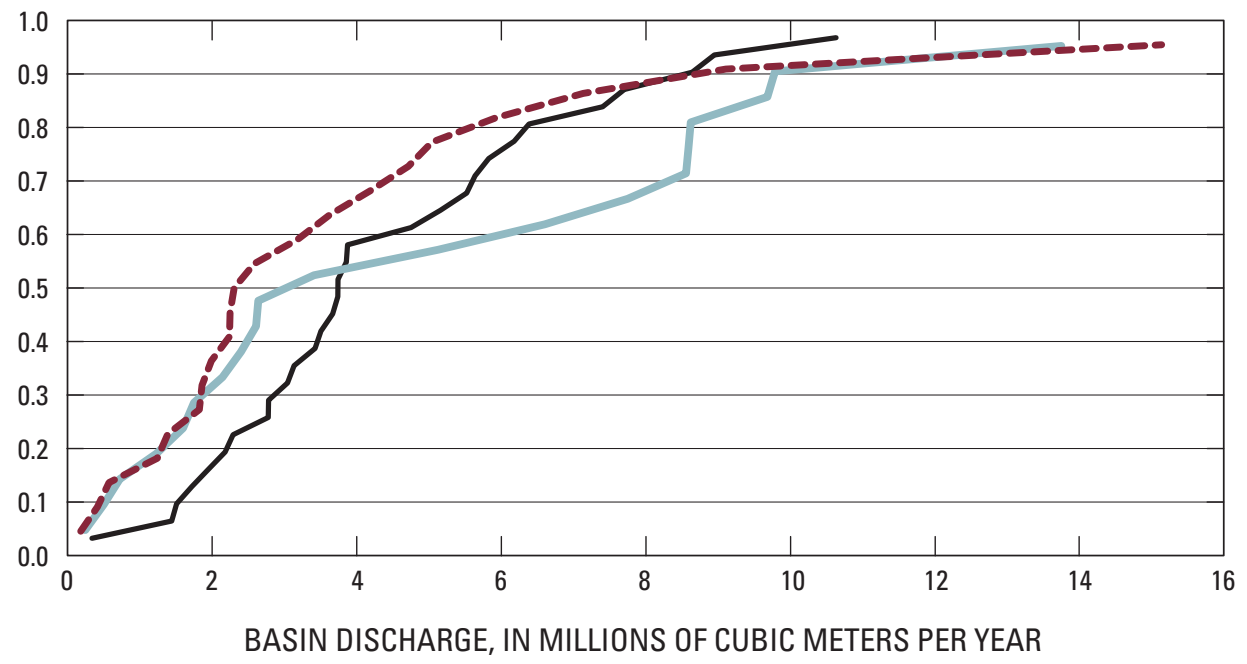




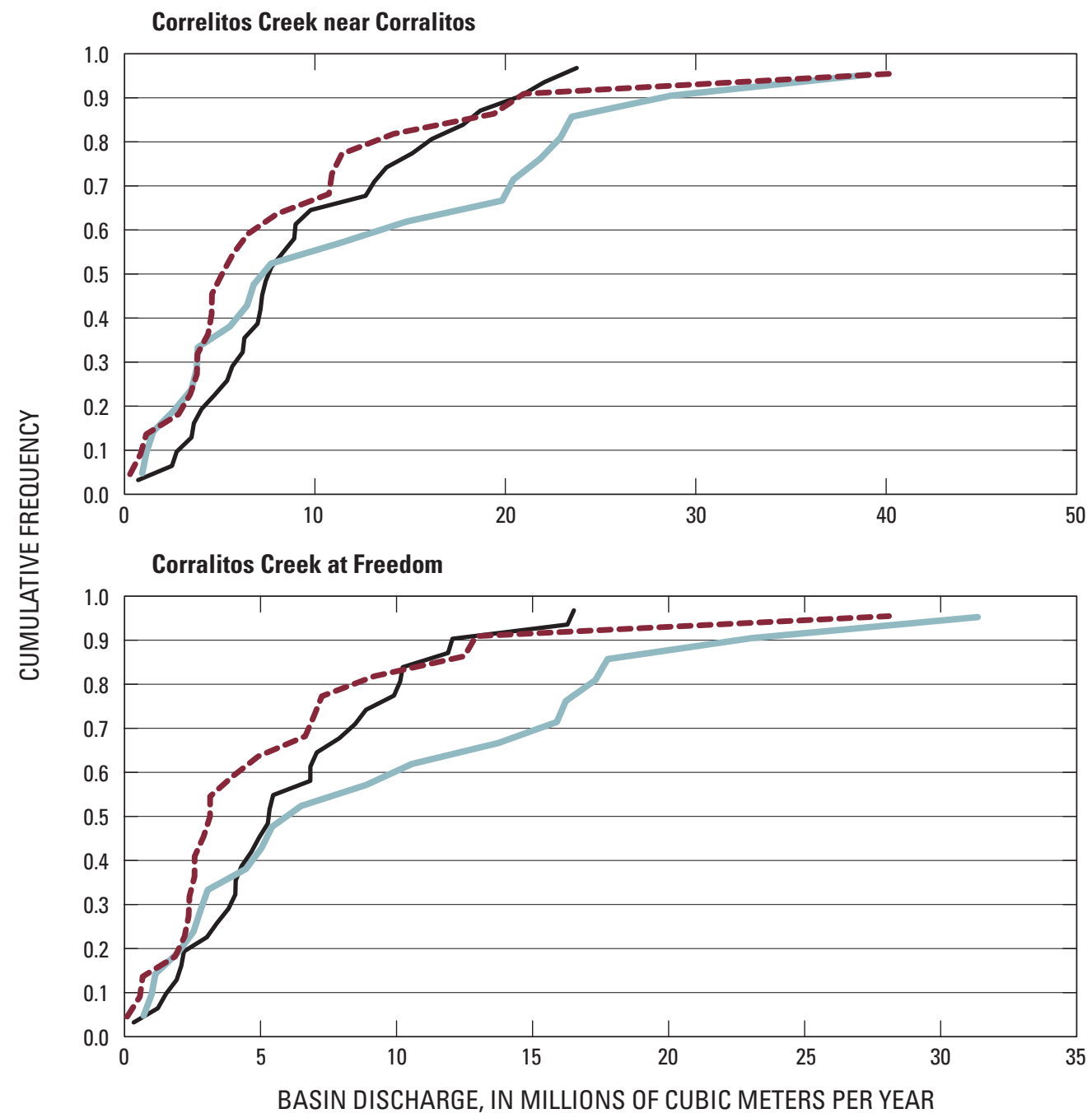

\section{EXPLANATION}

Historical 1990 to 2009

PCM-A2 2080 to 2099

GFDL-A2 2080 to 2100 


\section{Appendix 3}

Mean 30-Year Values for Climate and Water-Balance Components for Current and Four Future Projections for Major Water Supply Basins in the Santa Cruz Mountains, California 


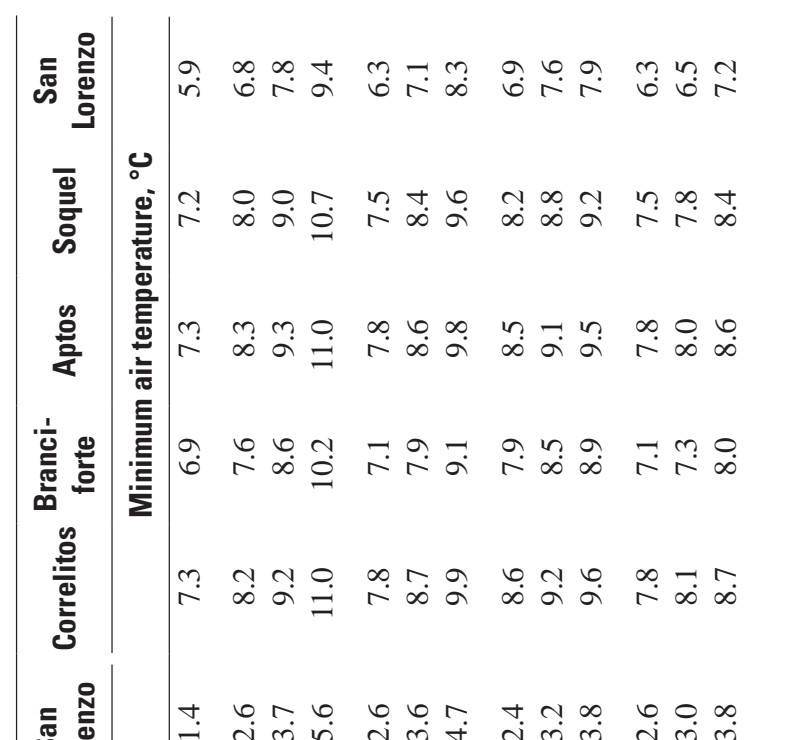

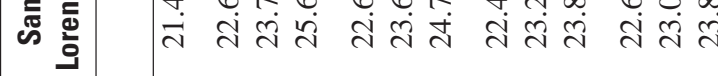

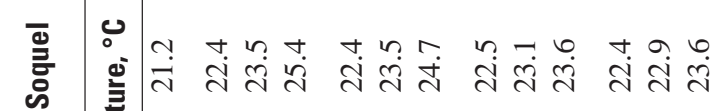

产

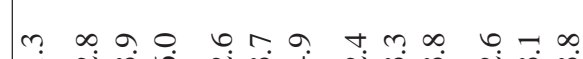

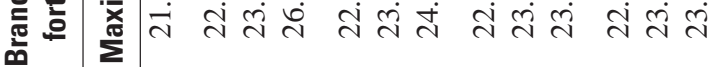

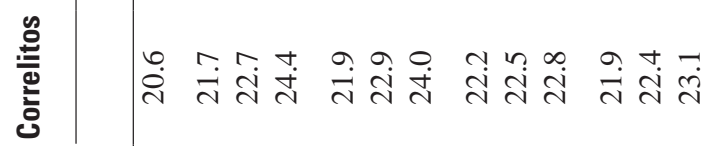

๘ॉ

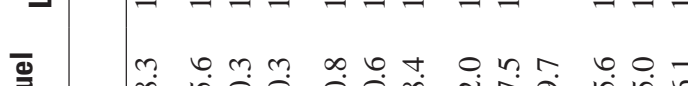

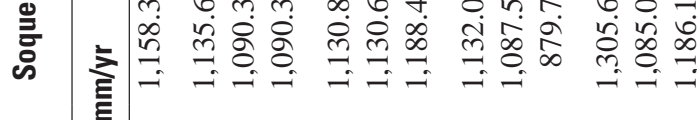
¿ โ

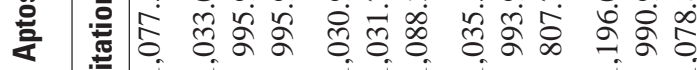
‘

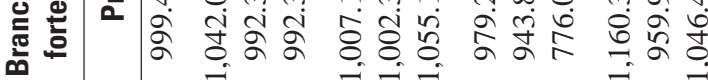

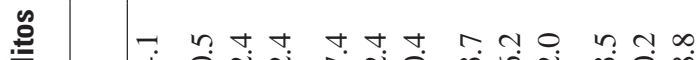
ப்

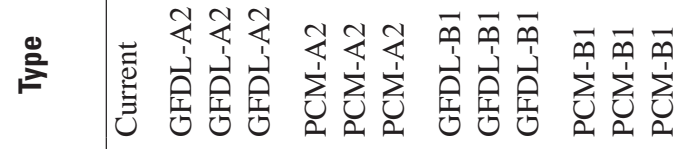
흫

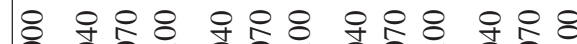
तิ ণ্ণ

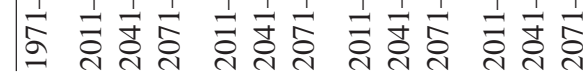

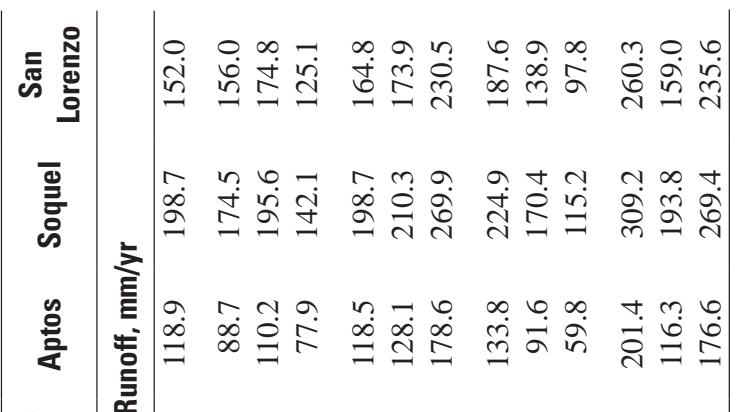

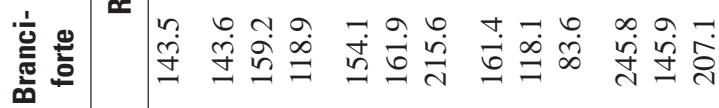
总

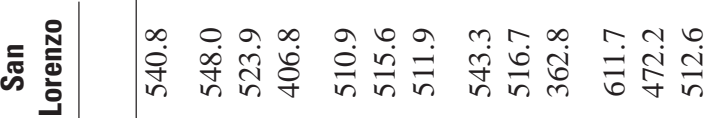
ब 㖣

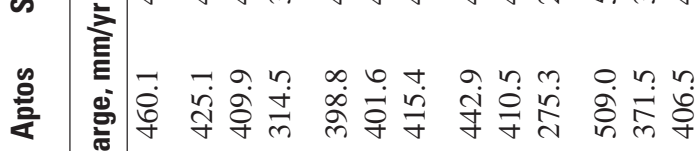

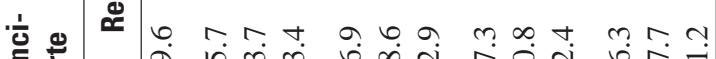

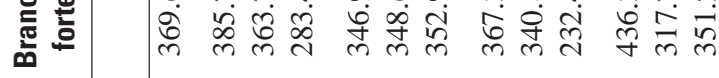

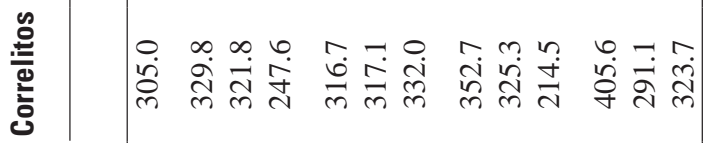

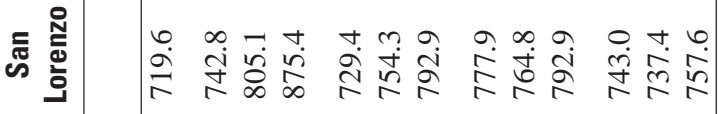

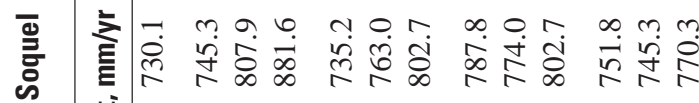

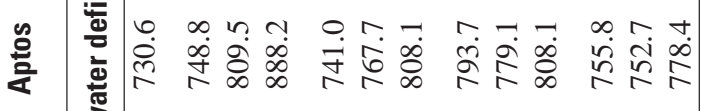

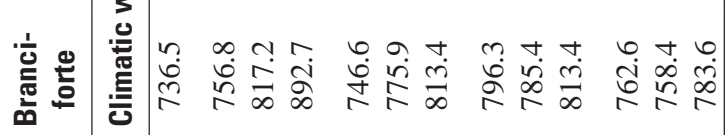

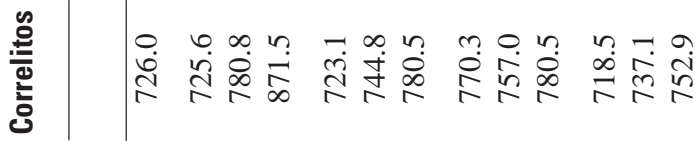

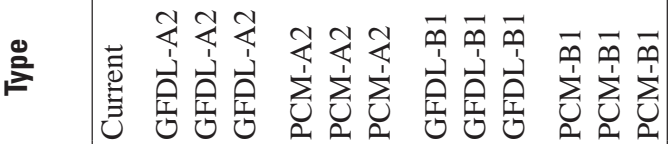

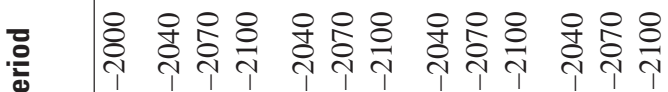

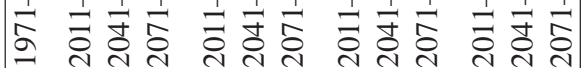





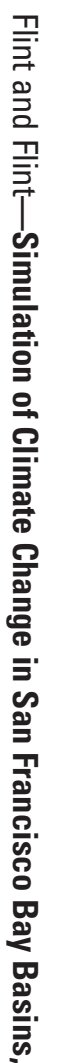

$\widetilde{0}$

.

69 Printed on recycled paper 